\title{
WestVirginiaUniversity
}

THE RESEARCH REPOSITORY @ WVU

Graduate Theses, Dissertations, and Problem Reports

2000

\section{Common factors leading to county boards of education financial deficits}

\author{
David L. Stewart \\ West Virginia University
}

Follow this and additional works at: https://researchrepository.wvu.edu/etd

\section{Recommended Citation}

Stewart, David L., "Common factors leading to county boards of education financial deficits" (2000). Graduate Theses, Dissertations, and Problem Reports. 2340.

https://researchrepository.wvu.edu/etd/2340

This Dissertation is protected by copyright and/or related rights. It has been brought to you by the The Research Repository @ WVU with permission from the rights-holder(s). You are free to use this Dissertation in any way that is permitted by the copyright and related rights legislation that applies to your use. For other uses you must obtain permission from the rights-holder(s) directly, unless additional rights are indicated by a Creative Commons license in the record and/ or on the work itself. This Dissertation has been accepted for inclusion in WVU Graduate Theses, Dissertations, and Problem Reports collection by an authorized administrator of The Research Repository @ WVU.

For more information, please contact researchrepository@mail.wvu.edu. 


\title{
Common Factors Leading To County Boards of Education Financial Deficits
}

\author{
David L. Stewart \\ Dissertation submitted to the \\ College of Human Resources and Education \\ at West Virginia University \\ in partial fulfillment of the requirements \\ for the degree of
}

Doctor of Education

in

Educational Leadership Studies

Phyllis C. Durden, Ed.D., Chair

Carolyn R. Arrington, Ed.D.

Ronald B. Childress, Ed.D.

Floyd L. Stead, Ed.D.

Jack E. Yeager, Ed.D.

Department of Advanced Educational Studies

Morgantown, West Virginia

2000

Keywords: Factors, Boards of Education, Financial Deficit, West Virginia 


\section{ABSTRACT \\ Common Factors Leading To County Boards of Education Financial Deficits}

\section{David L. Stewart}

This study reviewed and analyzed budget deficits incurred by county boards of education in West Virginia and determined why increasing numbers of county boards of education have experienced deficit spending since the enactment of Senate Bill 14.

This study utilized a descriptive research design. The West Virginia Department of Education provided deficit, enrollment, and personnel data; all fifty-five county superintendents and treasurers were surveyed to determine the frequency and cause of budget deficits. One hundred percent of both groups responded to the survey.

In conclusion, factors contributing to county boards of education experiencing financial deficit included: 1) reduction of numbers of employees allowed and funded in the school aid formula; 2) absence of excess levies; 3) reduction in state aid, under-funding by legislature, and timing of the reductions; 4) expansion of types of personnel included in definitions of teacher and professional instructional personnel; 5) decline in student enrollment; 6) poor financial decisions; and 7) excessive operations. 


\section{TABLE OF CONTENTS}

$\underline{\text { Page }}$

\section{CHAPTER 1 - INTRODUCTION}

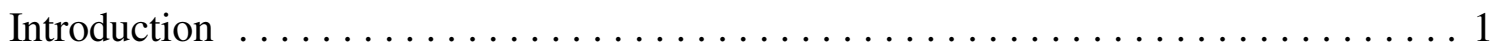

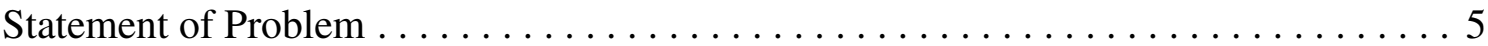

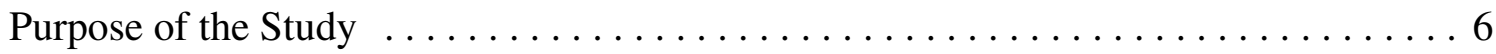

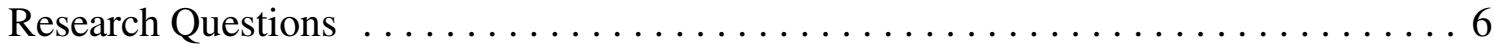

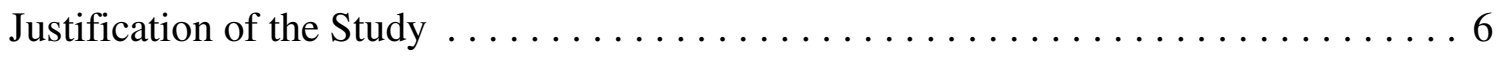

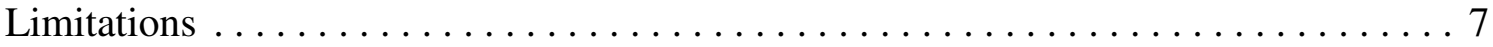

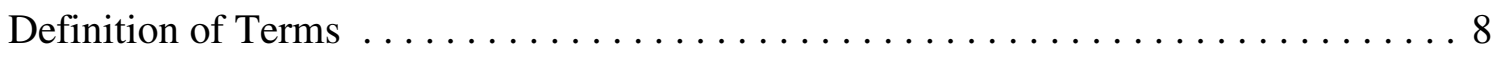

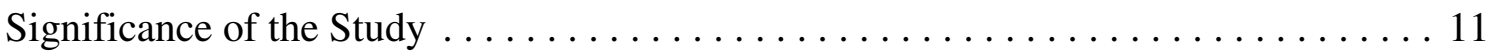

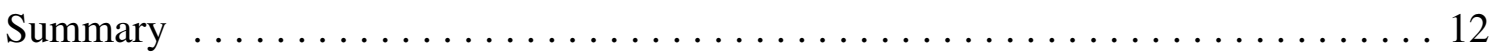

\section{CHAPTER 2 - REVIEW OF THE LITERATURE}

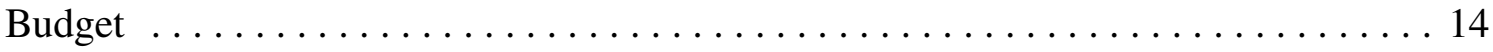

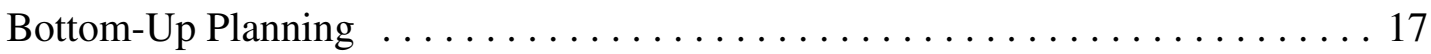

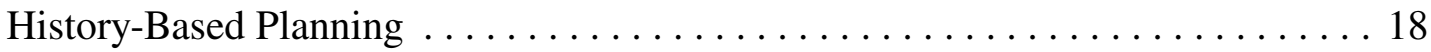

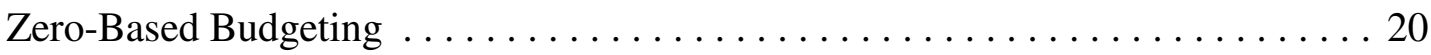

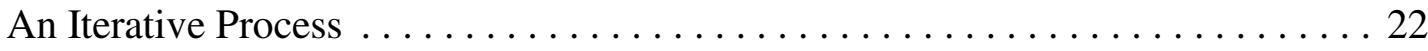

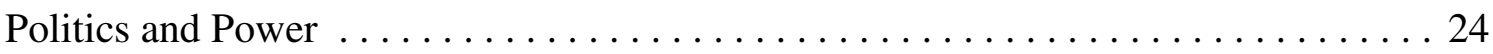

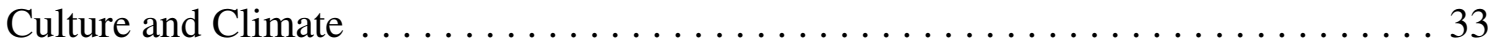

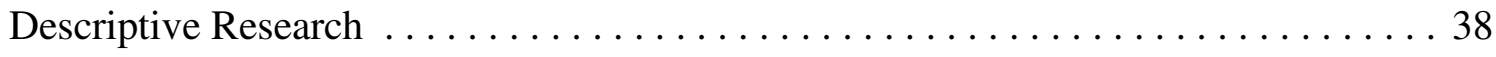

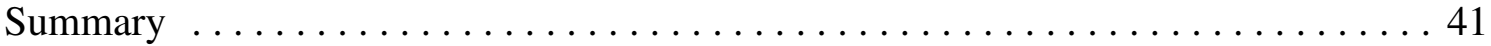




\section{CHAPTER 3 - METHOD AND RESEARCH DESIGN}

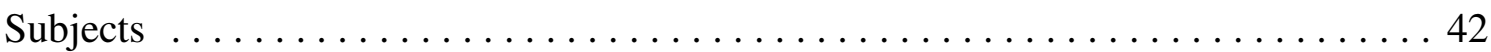

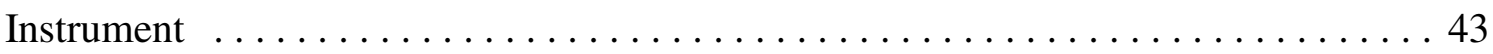

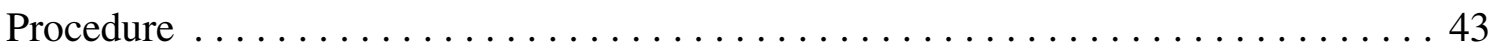

Data Analysis . ..................................... 44

\section{CHAPTER 4 - RESEARCH FINDINGS}

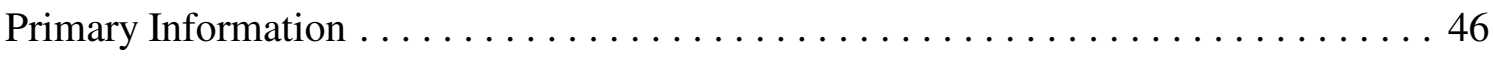

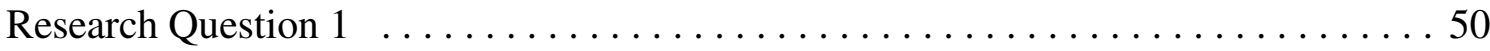

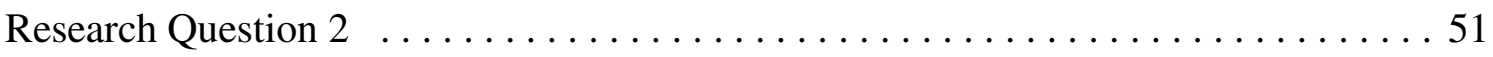

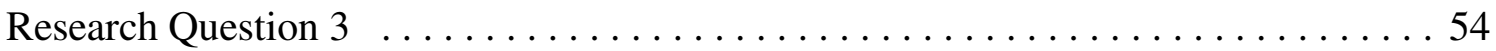

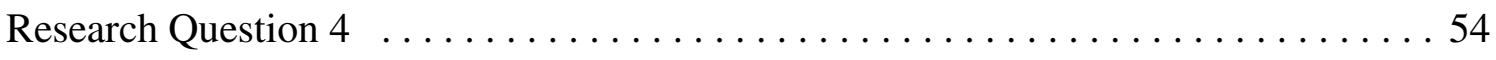

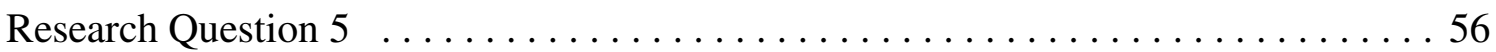

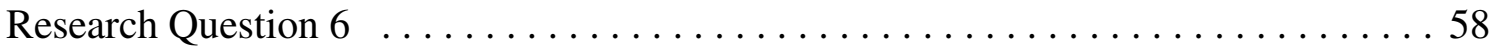

Anecdotal Data ....................................... 59

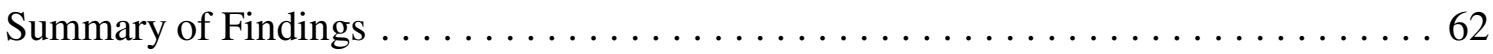

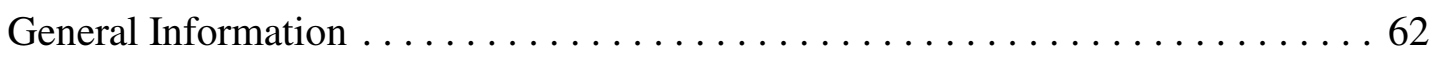

Summary of Findings for Each Research Question ................. 63

Anecdotal Comments ................................ 73

CHAPTER 5 - CONCLUSIONS AND RECOMMENDATIONS

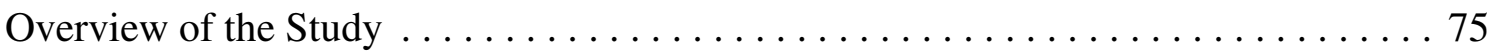

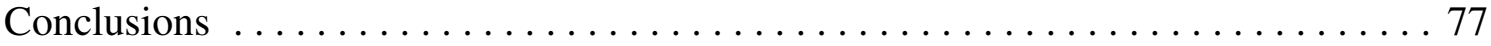


CHAPTER 5 - CONCLUSIONS AND RECOMMENDATIONS (continued)

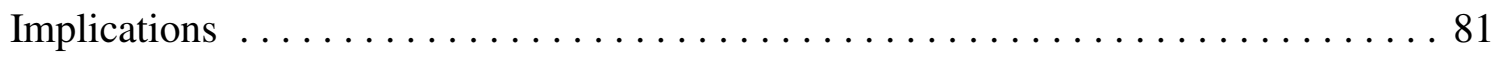

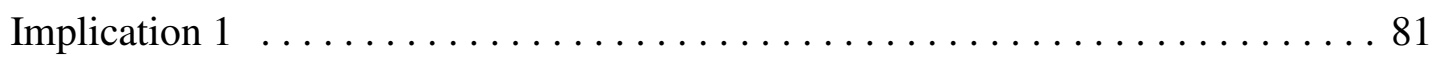

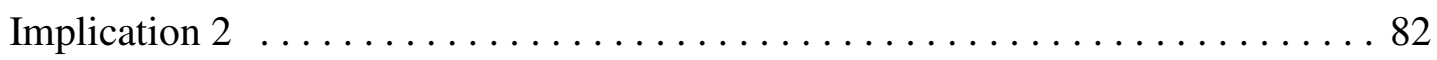

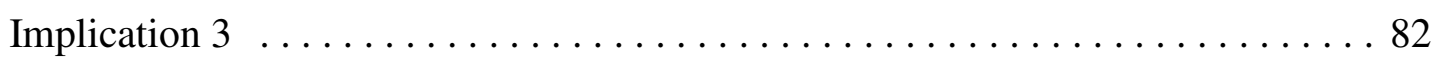

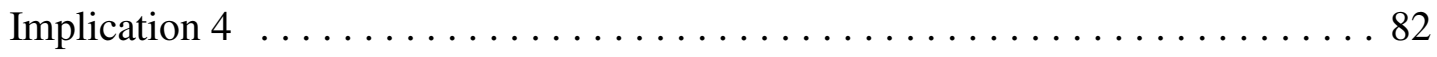

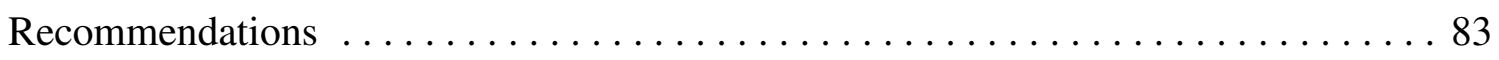

West Virginia Legislature $\ldots \ldots \ldots \ldots \ldots \ldots \ldots \ldots \ldots \ldots \ldots \ldots \ldots$

West Virginia Department of Education $\ldots \ldots \ldots \ldots \ldots \ldots \ldots \ldots \ldots \ldots$

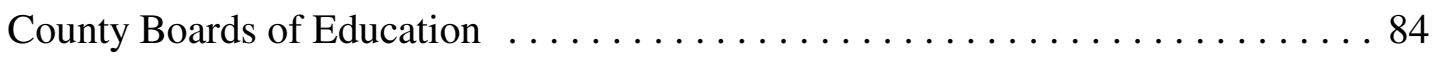

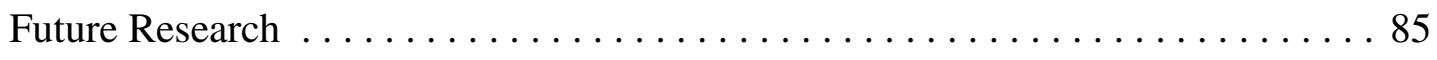

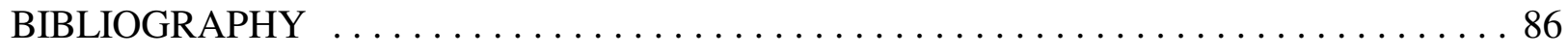

\section{APPENDICES}

Appendix A - County Boards of Education Data ..................... 91

Appendix B - Panel of Experts Who Reviewed Survey Instrument $\ldots \ldots \ldots \ldots 106$

Appendix C - Superintendent and Treasurer Letters and Questionnaire . ........ 108

Appendix D - Approval Letter of Application for Exemption .............. 115

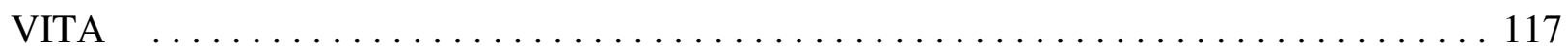




\section{LIST OF TABLES}

$\underline{\text { Page }}$

Table 1 - Comparison of Total Personnel Employed (All Funding Sources) and Enrollment Between 1987-1988 and 1996-1997 School Years

Table 2 - Comparison of Personnel Allowed in the Formula Between School

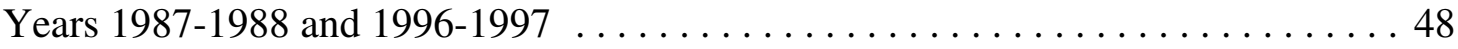

Table 3 - County Boards with Deficit Unreserved Fund Balances General Current Expense Fund at June 30, 1988 and $1997 \ldots \ldots \ldots \ldots \ldots \ldots \ldots \ldots$

Table 4 - Reduction of Personnel Funded as a Cause of Increased Incidence of

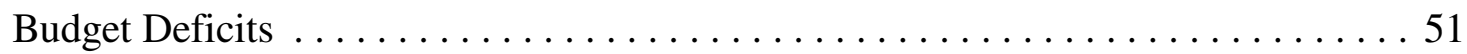

Table 5 - Steps Taken by County Boards of Education to Avoid Deficit Spending . . . . . 52

Table 6 - Number of County Boards of Education Experiencing Budget Deficits Prior to 1988 as Reported by Superintendents and Treasurers . . . . . . . . . . . . 54

Table 7 - County Board of Education Policies and Practices Continually Implemented

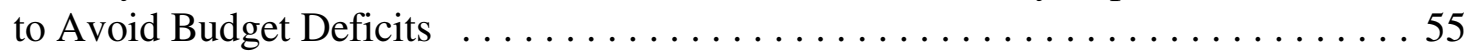

Table 8 - Impact of Closure and Consolidation to Avoid Deficit Spending . . . . . . . 56

Table 9 - Continuing Budget Deficits Effect on Academic and Extracurricular

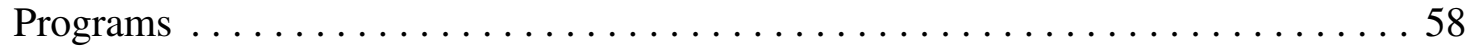




\section{CHAPTER 1}

\section{INTRODUCTION}

The West Virginia Legislature, in 1988, enacted reform legislation which directed the reduction of personnel in the fifty-five county boards of education throughout the state. The reduction of personnel allowed and funded by the Public School Support Program, hereafter referred to as the school aid formula or formula, resulted in less revenue to the county boards of education from the school aid formula. Prior to Senate Bill 14, the West Virginia Code, hereafter referred to as WV Code, in Chapter 18, Article 9A, permitted county boards of education to increase the number of professional educators and service personnel employed, with restrictions, using funds from the school aid formula. The increase in number of professional and service personnel allowed and funded within the school aid formula was a derivative of the adjusted enrollment of the districts. Prior to legislative action, adjusted enrollment was a calculation of the number of full-time students plus the number of special education students whose number was given an additional weighting. Using this method of calculating adjusted enrollment in the school aid formula, county boards of education provided programs in the area of special education which were labor intensive and caused the employment of additional personnel. It was the opinion of many, including legislators, that the increase in employees in the school districts coupled with a decline in enrollment did not foster the efficient operation of the public schools. 
Educators, on the other hand, believed that the school aid formula provided too few personnel and funds to provide a thorough and efficient education to the students within the various counties.

The legislature was concerned about continual increases in adjusted enrollment in spite of the decline of the number of students in net enrollments. In 1988 the legislature enacted changes to the funding mechanism which caused the increasing employment of personnel when there was a corresponding decrease in pupils in the school districts. The changes created maximum caps on the number of personnel who were allowed and funded within the school aid formula to be a calculation based on net enrollment. WV Code $\S 18-9 \mathrm{~A}-5$ a provided the implementation of the net caps over a six-year period beginning with the school year 1989-1990. The implementation schedule of the net caps was as follows:

\begin{tabular}{lcc}
$\begin{array}{l}\text { For the } \\
\text { school year }\end{array}$ & $\begin{array}{c}\text { Maximum professional } \\
\text { educators per 1000 } \\
\text { net enrollment the } \\
\text { preceding year }\end{array}$ & $\begin{array}{c}\text { Maximum service } \\
\text { personnel per 1000 } \\
\text { net enrollment the } \\
\text { preceding year }\end{array}$ \\
\cline { 2 - 2 } $\begin{array}{l}\text { preces } \\
1989-90\end{array}$ & 76.50 & 45.50 \\
$1990-91$ & 76.00 & 45.00 \\
$1991-92$ & 75.50 & 44.50 \\
$1992-93$ & 75.00 & 44.00 \\
$1993-94$ & 74.50 & 43.75 \\
$1994-95$ and & 74.00 & 43.50 \\
thereafter & &
\end{tabular}

Along with the reduction of personnel came a reduction in funding provided by the school aid formula. Many educators predicted this reduction would force county boards of education into a deficit net balance at the end of the fiscal year. Those counties without an 
excess levy, which provides funding in addition to the school aid formula, were particularly vulnerable. The excess levy revenue is needed to employ all staff in addition to that allowed and funded through the school aid formula. County boards of education without an excess levy were forced to reduce the number of personnel to the number provided for in the school aid formula or face the possibility of incurring deficit spending.

The West Virginia Legislature enacted Senate Bill 14 which mandated a decrease in personnel through school year 1995 that accelerated the normal reductions in personnel dictated from a decreasing enrollment. Additionally, in 1990, the legislature enacted further legislation which forced additional reductions of administrative staff within the school aid formula.

The reduction of staff mandated and funded by the legislature within the school aid formula and the corresponding reduction of revenue provided to the county boards of education from the school aid formula caused many to question the viability of the formula and its implication for causing deficit spending in the various county boards of education.

At the same time the school districts were experiencing reductions in staff and the corresponding reduction in funding, reductions occurred in state aid to schools during the fiscal years 1988-1989 through 1992-1993 with the exception of fiscal year 1990-1991. These reductions in funding were caused by the poor financial status of the state to provide for services through the general budget. The reductions in state aid to schools and the year in which the reductions occurred were as follows:

\begin{tabular}{|c|c|c|c|}
\hline $\begin{array}{c}3.0 \% \text { Reduction } \\
1988-1989\end{array}$ & $\begin{array}{c}2.0 \% \text { Reduction } \\
1989-1990\end{array}$ & $\begin{array}{c}1.0 \% \text { Reduction } \\
1991-1992\end{array}$ & $\begin{array}{c}\text { 1.5\% Reduction } \\
1992-1993\end{array}$ \\
\hline$\$ 20,921,723$ & $\$ 14,347,228$ & $\$ 8,000,678$ & $\$ 13,020,350$ \\
\hline
\end{tabular}


These additional reductions in state aid were particularly problematic because they were implemented after the preliminary budgets were developed by the county boards of education and personnel were under contract for the school year. This made it difficult for most counties to reduce expenditures in non-salary areas of the budget to provide for an operational budget that was realistic for the needs of the districts.

Along with the reduction of personnel and the reductions in state aid provided by the school aid formula, the formula was under-funded by the legislature in the school years 1989-1990 and 1990-1991. The years and amount of under-funding were as follows:

$\begin{array}{lll}\frac{1989-1990}{\$ 1990-1991} & \text { Total } \\ \$ 6,186,340 & \$ 4,500,000 & \$ 10,686,340\end{array}$

The final compounding fiscal action to county boards of education was an increase in the amount to be remitted to the Teachers Retirement System. The school aid formula was revised in 1988-1989 to make retirement allowance a part of the school aid formula rather than as a direct appropriation to the retirement system and to increase the rate gradually from 3.5 percent in 1988-1989 to 15 percent in 1995-1996. The retirement section was revised again in 1989-1990 to drop the gradual phase-in and the rate increased to 15 percent. The negative impact to county boards of education was related to personnel employed in addition to the number of personnel provided for in the school aid formula and for employment contracts for professional personnel whose term of employment exceeded two hundred days of employment. This was most critical because the formula funds professional personnel for two hundred days only. All employment days in excess of two hundred days for professional personnel must be funded by the county 
boards of education. Service personnel, on the other hand, are funded for actual days of contracted employment within the limits provided for in the school aid formula.

\section{STATEMENT OF THE PROBLEM}

The reduction of staff funded by the school aid formula and the resulting reduction in funding occurred more rapidly than would have been experienced with the normal decrease in enrollment. In addition to the reduction of the number of personnel allowed and funded in the school aid formula, the reductions in state aid, under-funding of the formula, and increase in retirement rates were devastating to the budget-making process by the county boards. Educators felt that the reductions would be fiscally devastating to the school districts. School board treasurers forecasted that the reduction in state aid for required positions would shift the expense to the local boards. Those county boards of education without excess levies had no source of funds outside of those provided in the school aid formula and subsequently the experience of annual budget deficits became a reality.

County boards of education in West Virginia have increasingly experienced budget deficits as reported on the annual financial statements. The number of county boards of education deficits decreased from seven in 1989 to five in 1990, increased to seventeen by 1994, and decreased to four in 1998. All of these deficits were reported after the reform movement of 1988. Senate Bill 14 initiated the first reduction of the number of professional and service personnel funded in the school aid formula. What effect did this change among others enacted by the legislature have on the financial operations of the county boards of education? Are the budget deficits caused by changes in the school aid formula, management response by the boards of education, or a combination of both? 


\section{PURPOSE OF THE STUDY}

The purpose of this study was to review and analyze budget deficits incurred by county boards of education in West Virginia and to determine why increasing numbers of county boards of education have experienced deficit spending since the enactment of Senate Bill 14.

\section{RESEARCH QUESTIONS}

Specific questions addressed by this study included:

1. To what extent did the reduction of personnel funded in the formula affect the increased incidence of budget deficits?

2. What steps did county boards of education take to avoid deficit spending?

3. Did county boards of education experience budget deficits prior to 1988 ?

4. What policies and practices are counties continually implementing to avoid budget deficits?

5. If closure and consolidation of schools were used to avoid deficit spending, what was the impact on their budgets?

6. What was the effect of continuing budget deficits on the academic and extracurricular programs?

\section{JUSTIFICATION OF THE STUDY}

Article XII, Section One of the Constitution for the State of West Virginia requires the legislature to provide for a thorough and efficient system of free schools. 
WV Code §11-8-26 provides that a local fiscal body shall not expend money or incur obligations: (1) in an unauthorized manner; (2) for an unauthorized purpose; (3) in excess of the amount allocated to the fund in the levy order; or (4) in excess of the funds available for current expenses. A proviso states, however, that a local fiscal body shall not be penalized for a casual deficit which does not exceed its approved levy estimate by more than three percent, provided such casual deficit be satisfied in the levy estimate for the succeeding fiscal year. WV Code $\S 18-1-1$ defines a casual deficit as "a deficit of not more than three percent of the approved levy estimate or a deficit that is nonrecurring from year to year."

Whenever a fiscal body expends money or incurs obligations in violation of WV Code $\S 11-8-26$, suit shall be instituted by the prosecuting attorney of the county or the attorney general of the State, in a court of competent jurisdiction to recover the money or to cancel the obligation or both.

Answers to questions regarding the cause of budget deficits are needed to provide for the adequate funding of the state's school system by the legislature and local fiscal bodies.

\section{LIMITATIONS}

1. The results of the study can be generalized only to West Virginia.

2. The study used surveys that limited the results to the opinions and perceptions of those responding.

3. The replacement of county superintendents and treasurers since 1988 may have influenced the responses to the survey though the information to complete the survey was available in each county board of education. 
4. The study used data available from the West Virginia Department of Education and county boards of education with accuracy and completeness subject to error as submitted by each county board of education.

\section{DEFINITION OF TERMS}

1. ADJUSTED ENROLLMENT: “Adjusted enrollment means the net enrollment plus twice the number of pupils enrolled for special education including exceptional gifted, plus the number of pupils in grades one through twelve enrolled in honors and advanced placement programs ..." (WV Code §18-9A-2).

2. ADMINISTRATION: Administration shall mean superintendent, deputy superintendent or associate superintendent, administrative assistant, director/manager (instructional), director/coordinator supportive services and curriculum specialist.

3. AFFECTED: Affected shall mean to have an influence on; bring about a change in (American Heritage Dictionary, 1985).

4. BUDGET: "The annual budget of school revenues and expenditures prepared and adopted by a county board of education ..." (WV Code $§ 18-9 B-2)$.

5. CENTRAL OFFICE STAFF: Central office staff shall mean superintendent; deputy, associate and assistant superintendent; administrative assistant; director/coordinator of instruction; dental hygienist; social worker; physical therapist and occupational therapist.

6. CONSOLIDATION: Consolidation shall mean the merging of students in one or more schools into one facility. 
7. COUNTY BOARDS OF EDUCATION: County boards of education shall be synonymous with school districts.

8. DEFICIT: Deficit shall mean a negative unreserved (net) fund balance as presented in each school district's audited annual financial statement.

9. EXCESS LEVY: Excess levy shall mean an additional levy approved by the voters within a county to support education. The excess levy must be approved by a majority of the voters who cast their ballot in favor of the additional levy. Levies authorized by the voters shall not continue for more than five years without resubmission to the voters. This definition shall not include a "Bond Levy" generally used for construction, renovation, or capital improvements.

10. FISCAL YEAR: According to WV Code $\$ 2-2-4$, the fiscal year for the state and all political subdivisions must begin on July 1 and end on June 30 .

11. NET ENROLLMENT: The number of students enrolled in pre-kindergarten through grade twelve and special education programs in the public schools of a county, reported on a full-time equivalency (FTE) basis (WV Code §18-9A-2).

12. MAINTENANCE: Maintenance shall mean the function of repair and renovation of school facilities.

13. MAINTENANCE PERSONNEL: Maintenance personnel means supervisor of maintenance, cabinet maker, carpenter, crew leader, electrician, electronic technician, foreman, general maintenance, glazier, handyman, HVAC mechanic, mason, custodian, watchman, welder, sanitation plant operator, groundsman, painter, plumber and roofer/sheet metal mechanic (WV Code §18A-4-8). 
14. OTHER SUPPORT PERSONNEL: Other support personnel shall mean physician, nurse (below AB), attendance officer, social worker, dental hygienist, physical therapist, occupational therapist and audiologist.

15. PERSONNEL: Personnel shall mean those persons employed on a full-time equivalency by a county board of education.

16. PRINCIPAL: Principal includes the principal and all assistant principals and means the professional educator who as an agent of the board is responsible for the supervision, management and control of a school.

17. PROFESSIONAL EDUCATOR: "Professional educator shall be synonymous with and shall have the same meaning as teacher in section one, article one, chapter eighteen of this code" (WV Code $§ 18-9 A-2)$.

18. PROFESSIONAL INSTRUCTIONAL PERSONNEL: "Professional instructional personnel shall mean a professional educator whose regular duty is that of a classroom teacher, librarian, counselor, attendance director, school psychologist or school nurse with a bachelor's degree who is licensed by the West Virginia board of examiners for registered professional nurses" (WV Code §18-9A-2).

19. PROFESSIONAL NON-INSTRUCTIONAL PERSONNEL: Professional noninstructional personnel shall mean all professional educators that are not included in the definition of professional instructional personnel (WV Code §18-9A-2).

20. PROGRAM (ACADEMIC OR EXTRACURRICULAR): Program shall mean all educational offerings or services provided by county boards of education, such as 
child nutrition, transportation, curriculum supervision, academic areas, extracurricular and so forth.

21. SCHOOL DISTRICTS: School districts shall by synonymous with county boards of education.

22. SERVICE PERSONNEL: Personnel employed by a board of education under any of the class titles identified in WV Code $§ 18 \mathrm{~A}-4-8$.

23. SUPERINTENDENT: The chief executive officer of the school district. . (WV Code $§ 18-1-1)$.

\section{SIGNIFICANCE OF THE STUDY}

The West Virginia Legislature enacted changes to the method of funding the public schools in order that the number of employees within the county boards of education would reflect the number of students enrolled. Soon after the reform legislation, an increasing number of counties began to experience budget deficits. Prior to the reform legislation the county boards of education had seldom reported deficit spending on their annual financial reports.

This study attempted to gather data describing the increased incidence of budget deficits and the factors leading to deficit spending. The data presented and analyzed will enable county boards to predict a budget deficit and take corrective action to inhibit the financial chaos that follows deficit spending.

The results of the study will be valuable to the West Virginia Department of Education in providing technical assistance to the counties experiencing difficulties in developing and operating an annual budget which will not result in deficit spending. 
The common factors contributing to financial deficits identified in the study may assist the legislature in implementing and passing positive legislation pertaining to school funding.

\section{SUMMARY}

Legislation enacted by the West Virginia Legislature in 1988, 1989, and 1990 reduced the amount of funds provided through the school aid formula by reducing the number of personnel allowed and funded. The legislature felt the changes were necessary because the number of personnel funded through the formula were not decreasing as rapidly as the reduction of students in net enrollment. Soon after the reform legislation was passed county boards of education began reporting financial deficits. The purpose of the study was to describe the common factors which were experienced by the fifty-five county school districts that predicated budget deficits.

In Chapter 2, the researcher reviews relevant literature used to guide the study. The literature describes the function of the budget as a planning tool and suggests strategies for sound budget development and operation.

Chapters 3, 4, and 5 deal with the study and it results. The research methods used in collecting the information needed to study the experience of deficit financial budgets in West Virginia are discussed in Chapter 3. The data are presented in Chapter 4 and the conclusions reached by the researcher as a result of analyzing the data are discussed in Chapter 5. County board of education data are included in Appendix A identified as enrollment, Tables A-1 and A2; total personnel, Table A-3; professional personnel, Table A-4; service personnel, Table A-5; personnel allowed in the formula, Table A-6; professional personnel allowed in the formula, Table A-7; service personnel allowed in the formula, Table A-8; history of unreserved fund balance, Table A-9; excess levies in effect 1996-1997 school year, Table A-10; excess levies in 
effect 1987-1988 school year, Table A-11; change in student enrollment, Table A-12; and comparison of unreserved fund balances for fiscal years ended June 30, 1988 and June 30, 1997, Table A-13. 


\section{CHAPTER 2}

\section{REVIEW OF LITERATURE}

Chapter 2 contains a literature review of writings concerning budget, politics and power, and culture and climate in the public schools and descriptive research. This chapter does not include an exhaustive summary of those topics.

\section{BUDGET}

For budgeting purposes, the education sector is referred to as a non-profit organization. The function of the budget is not to measure and provide for a profit to the corporation. However, the budget must be constructed in a professional manner following the financial principles developed and utilized in profit-making entities. In the education arena some form of planning tool is essential to ensure that activities meet objectives. The major planning tool is the budget. The budget is the formal statement of expected resources and proposed expenditures. In many government units, the budget is deemed so significant that it may be in legal form with limits placed on government expenditures. The budget requires formal approval of the local board of education and the state department of education. "The education budget process includes long-range planning, program planning, budget planning, budget development, and budget control" (Shim and Siegel, 1994, p. 534). 
The education organization must find an alternative method to quantify its success (other than profit) to control its operations, to appraise performance, and to make resource allocation decisions. This increases the need for education agencies to formulate priorities before budget development.

The annual budget should be a powerful management tool, a school district's most useful planning document, but often it is not. There are numerous inherent problems associated with budgeting that can make it a source of pain rather than satisfaction. In some school districts, the budget is treated as a necessary evil. How unfortunate, when it is the one planning/management document that is referred to almost every day in most school systems.

Because almost every manager in the school system is involved in budgeting, it should be a valuable management tool; however its importance goes far beyond that. The budget expresses, quantitatively and in detail, what the organization plans to do the next year and what results it expects. It states how available resources will be employed and deployed and what additional resources will be needed. It communicates where emphasis and priority will be placed and the performance to be measured. Additionally, it supplies this information not in the abstract but in the specifics of people, dollars, equipment, instructional areas, buildings, and programs. "In short, the budget is what gives reality to the school system's objectives and strategies" (Finney, 1993, p. 9).

Good budgeting leads to good management, which in turn leads to good educational performance in the school system. Not taking advantage of this powerful force for better performance is an unaffordable handicap in any educational situation. 
The objective of financial reporting is accountability to the public rather than to investors. There is no profit distribution. "The accounting equation is: Assets $=$ Restrictions on Assets. A county board of education may have a surplus or deficit depending on whether revenues exceed expenditures" (Shim and Siegel, 1994, p. 534). In West Virginia a county board of education may operate a budget which results in a deficit. However, the deficit must be resolved in the budget adoption of the next succeeding fiscal year. The adopted budget is the maximum amount the organization can spend.

"Education organizations need budgets to formulate planning and control of activities. Expected revenue must be matched with appropriations. Revenue must be spent in accordance with regulations and law" (Shim and Siegel, 1994, p. 565).

Budgeting is a management problem, not an accounting problem. Powerful budgeting requires a behavioral approach to a process that develops the best possible information, encourages excellence throughout the school system, and overcomes the inherent problems of budgeting. The guiding principle must be "thinking it through before crunching the numbers" (Finney, 1993, p. 10).

School systems are characterized by their differences and by their similarities. Every system has its own unique set of problems and parameters of operations, but it is equally true that a large body of principles apply to every school system. Similar approaches and techniques can be applied beneficially in almost any school system in the quest for budget making, as long as the system adapts the techniques and processes to its own specific situation. 
The word budget as used in school systems in West Virginia means the financial plan for the period of a year. Budget always means annual budget. In West Virginia the annual budget coincides with the fiscal year which commences on July 1 and ends on the next June 30.

Educators are generally smart, aggressive, and results oriented. Give them a problem in the teaching and learning arena and they will attack it with vigor. When you say, "Let's prepare next year's budget," however, their behavior often appears to be irrational. Most often this is a result of the school system not having in place a strong budget planning method and model.

While some school systems do no formal planning and others seem to plan and replan again, revisiting the same information continuously, most systems fall somewhere in the middle. Many systems have a strategic plan; all systems have an annual budget; all systems have goals, objectives, and expectations, even if they are not all formally written down. There are a great many methods for budget planning. Some of the more effective approaches will be explored.

\section{Bottom-Up Planning}

The first efforts at planning and budgeting by a school system often fall into the "bottomup" category. "In this generally unsophisticated process, top management establishes the expectations, and directs the budget manager to set a budget to achieve results in the targeted areas" (Sherman, 1994, p. 2).

"The mechanics of the bottom-up approach are such that lower level managers and personnel have little input into the budget content or projected results. As a result, budget operation is usually based upon job security issues and does not provide any assurances that objectives will be achieved" (Sherman, 1994, p. 3). Perhaps more important, the failure to achieve the budget goals often brings an "It wasn't my budget" response to criticism. 
In the context of school system budget management, the distribution of resources will probably be consistent with or proportional to prior year amounts unless some particular category or group needs or justifies a disproportionate allocation. In such a case, all other categories or groups will be budgeted or projected at lower amounts without any particular justification involved. In any event, budgeted levels are subjectively rather than objectively assigned. This model is prevalent in many school systems in West Virginia.

\section{History-Based Planning}

A variation on bottom-up planning is "top-down" planning. In this instance top management establishes the goals and objectives of the budget. Utilizing the revenue target or projection as the beginning point, the remainder of the plans and budgets are established on a proportionate basis. There is little effort to recognize the need to change the budget pattern from that based upon past practice and revenue projections. The long and short term performance that result again do not have the commitment of lower level management. This method appears to be more scientific because the available revenue is often established as an extrapolation of historic revenues available.

The theory of this practice is that the recent past is the best predictor of the near future. "However, with the increased computing capabilities now available, a number of variations on the history-based planning have emerged. Computers permit increased complexity and sophistication in the planning process" (Sherman, 1994, p. 4).

In its simplest case, history-based planning is the extrapolation of prior performance to project future results. While this process is valuable and appropriate for financial needs approximation, it does not provide for the commitment of the line management, school 
principals, and organization to its delivery. This linear estimation, all elements and lines of the budget retaining the same relationship to projected revenues as has been true historically, in effect, assumes that all expenditures are variable.

It is interesting to observe that a comparison of budgets over time seems to support such a conclusion. This may be the result of the phenomenon of "self-fulfilling analysis." Another interesting observation is that although school system budgets have continued to increase over the past decade, the relationship between the areas of budget expense appropriation has not changed significantly.

This simply means that as soon as revenues have been estimated all line items will be adjusted and no additional planning needs to take place. The interesting outcome is that the future looks like the past and all outside the norm adjustments are difficult to implement. This makes an excellent predictor of financial failure resulting in a deficit situation for county boards of education using this model.

The time trend forecast may be based on an arithmetic average of period changes of several prior periods' data in the form of

$$
Y_{i}=Y_{i-x}(1+g)^{x}
$$

where

$$
\begin{aligned}
& \mathrm{x}=\text { the number of periods of source data } \\
& \mathrm{i}=\text { period to be forecast } \\
& \mathrm{g}=\text { the calculated rate of change that fits the line being computed to the data observed }
\end{aligned}
$$


Consider the following example:

$$
\begin{aligned}
& 19 X 1 \text { Revenue }=100,000 \\
& 19 X 2 \text { Revenue }=109,000 \\
& 19 X 3 \text { Revenue }=118,800 \\
& 19 X 4 \text { Revenue }=129,500 \\
& 19 X 5 \text { Revenue }=141,150 \\
& 19 X 6 \text { Revenue }=154,000
\end{aligned}
$$

In this case $\mathrm{g}=9$ percent and the projection for 19X7 would be 167,700 (Sherman, 1994, p. 6).

This type of budget forecasting is not intended to be statistics-focused. However, it is important to recognize that the projection of future revenues to serve as the basis of budget planning is the result of just such a calculation. A budget or a long-range plan predicated on such statistical projections may be valid, but it risks failure because there is no direct commitment or ownership by the people who have to deliver the educational goals and objectives of the school system. It is just this commitment that is needed to make the future of the school system budget successful.

\section{Zero-Based Budgeting}

"Zero-based budgeting is not a principally or primarily a budgeting or planning process" (Sherman, 1994, p. 9). Rather, it is a management approach to the direction of the school system. It requires more management on the part of the administrators and includes an intensive analysis of all of the activities and efforts undertaken by the school system. It requires that managers establish objectives, identify alternative means to achieve those objectives, determine the funding required to support the needs of those objectives, identify appropriate means of measuring 
achievement, and establish school system priorities. It is only after these basic steps have been undertaken that the financial planning part of the process begins.

Zero-based budgeting requires that the planned expenditures for each budget category be justified in its entirety every year. The fact that an amount was planned or budgeted in one planning cycle is not a valid basis for requesting or being assigned a particular amount, or any amount at all, in the subsequent planning and budgeting cycles.

This system, with its focus on justification of expenditures, imposes a high degree of cost-consciousness on all participants in the budget-making process. It places high value on identifying alternative, cost-efficient ways to accomplish tasks and helps to assure that practices do not get entrenched in the expenditure budget.

"Zero-based budgeting and planning seems to impose a tremendous work burden on all functions and personnel involved, but the process becomes structured, with systematic information development and presentation" (Sherman, 1994, p. 10). In time, focus concentrates on the more discretionary functions and activities. However, because of the discipline imposed on all functions within the school system, the planning and budgeting process compels all budget managers to understand the financial resources and requirements of the school system.

Drawing on Time-Trend Extrapolation and Zero-Based Planning as starting points, one can envision a planning and budgeting process that integrates the long-term aspects of strategic planning and the short-term focus on the annual budget to provide the board of education and administration with a clear picture of where the school system is going and how, in the short run, it plans to get there. To accomplish this requires a structure; planning does not happen by accident. By making planning a continuous process, it forces the board and administration to 
incorporate the planning process into regular activities. It is not possible to segregate planning and budgeting from the other responsibilities of the board and administration. There are planning-related activities at all times during the year. With a planning and budgeting calendar in place a school system maintains momentum toward achieving its goals and objectives. The school system, board of education members, and administrators remain focused on the flow of information and the effect that events have on future results and budgets.

It is important to remember that all activities within the school system are interrelated. The results of one budget period influence the expectations of the next. The assumptions made about curriculum and facilities will influence forecasts, hiring practices, spending plans, and the overall atmosphere within the school system. "The better the planning, the more likely the outcome will meet the expectations" (Sherman, 1994, p. 8). Therefore, the school system that does the best job of preparing itself, of planning its activities, will be more successful over time in avoiding deficit spending in its budget operation.

Although budgeting activity is a continuous process, it should not take precedence over the operation of the school system. Rather, it complements the learning process by relating results to expectations and by relating expectations to previous results. County boards of education and administrators should reinforce this perception.

\section{An Iterative Process}

The planning process is never finished. In many school districts the budgeting process is closed upon adoption of the annual budget. However, as a school system completes one step, it should begin the next. As one period's plan is completed, another period's planning should be started. And throughout the process, management is making decisions and taking actions that 
affect the next planning cycle. "However, at the end of each cycle the planning process stops, and a plan document is prepared. This written formal document, the budget, serves as the measurement basis for the fiscal year" (Sherman, 1994, p. 11).

The benefits of good budgeting practices far exceed the ability to establish and operate a balanced budget which results in a positive fiscal year net balance. Board members first want the school system to survive financially and they want it to produce quality graduates. "Management characteristics needed to achieve both goals include good decision-making skills, excellence in all activities, control of all activities, and intelligent and timely reaction to problems and surprises. Good budgeting provides the information, focus, and attitudes needed for each" (Finney, 1993, p. 198).

The biggest difficulties for most boards of education and administrators in both surviving and making their school systems successful are the uncertainty of the future and lack of control over outside environmental factors. Particularly important, major problems come from unpredicted change in the outside environment, ranging from the 1970 s oil shocks, to the asbestos-related expenditures in school buildings and the reduction of anticipated revenue from the local tax base and the state funding formula. "Reacting well in a timely fashion to unpredicted outside events is almost the definition of good management, and this is probably the area in which good budgeting can make its greatest contribution" (Finney, 1993, p. 199).

All too often in education, budgeting is deadening and demotivating. It is the place where vision and inspiration are killed by a bureaucratic exercise that seems uncoupled from the objectives and activities espoused by the board and administration. "Budgeting should be uplifting, challenging, and exciting" (Finney, 1993, p. 199). It can be a mechanism that brings 
the school system together to grapple with the opportunities and problems present within the system. Even in a negative situation in which fiscal survival is in question, the school system can be powerfully motivated by knowing and facing the real problems and planning their solutions. The final benefit of good budgeting, then, is the better results that follow from increased motivation and morale of the entire school system.

\section{POLITICS AND POWER}

The essence of organizational control is power. The classical definition of power is the ability to get others to do what you want them to do, or as Weber (1947, p. 152) defines it, "the probability that one actor within a social relationship will be in a position to carry out his own will despite resistance” (Hoy and Miskel, 1996, p. 171). School systems are created and controlled by legitimate authorities, who set goals, design curriculum, hire and manage employees, and assess activities to ensure behavior is consistent with the goals and objectives of the organization (Bolman and Deal, 1991).

The exercise of authority in public schools usually does not involve coercion as is often believed. Herbert A. Simon (1957, pp. 126-127) proposed that authority is distinguished from other kinds of influence or power in that the subordinate "holds in abeyance his own critical faculties for choosing between alternatives and uses the formal criterion of receipt of a command or signal as his basis of choice."

Authority is exercised when a common set of beliefs in the school system legitimizes the use of power as appropriate. Weber (1947) distinguishes three types of authority - charismatic, traditional, and legal - according to the kind of legitimacy typically claimed by each. 
Charismatic authority lies in the individual who is the leader by virtue of personal trust or exemplary qualities. "The authority of the charismatic leader results primarily from the leader's overwhelming personal appeal, and typically a common value orientation emerges within the group to produce an intense normative commitment to and identification with the person" (Hoy and Miskel, 1996, p. 172).

Traditional authority is grounded in the belief of the status of those exercising authority in the past. "Obedience is owed to the traditional sanctioned position of authority, and the person who occupies the position inherits the authority established by custom" (Hoy and Miskel, 1996, p. 172). Students accept the authority of the teacher because their parents did so before them. Legal authority has it roots in law. Obedience to legal authority is not to the person or position but to the laws that dictate the compliance. "In schools obedience is owed to the impersonal principles that govern the operation of the organizations" (Hoy and Miskel, 1996, p. 173).

Authority in a school system implies legitimacy, but not all power is legitimate. Groups often have power to influence the behavior of others in personnel and budgeting decisions. Leaders exercise power in persuading others to comply with their directives. Administrators have power by their position in the organization and they have the power of the organization. John R. P. French and Bertram H. Raven (1968) focus their analysis of power on the bases of interpersonal power within which they identified five kinds of power - reward, coercive, legitimate, referent, and expert.

Reward power is the administrator's ability to influence subordinates by rewarding their desirable behavior. This kind of power thrives on the attractiveness of the rewards and the 
certainty that the administrator can control the rewards. For example, a principal who can release teachers from routine housekeeping duties has reward power over teachers in that school. "It is important, however, that the rewards be linked to compliance and that the influence attempts are proper and ethical" (Hoy and Miskel, 1996, p. 176)

Coercive power is the administrator's ability to influence staff by punishing them for undesirable behavior. Coercive power has its strength in the severity of the punishment and the certainty that the punishment cannot be avoided. Hoy and Miskel (1996) observe that punishment is not without its negative effects. An official reprimand to a teacher for consistently leaving school early may result in frequent absenteeism, refusing to provide extra help to students unless specified in the contract, and a general tendency to avoid all but the essential aspects of the job. Interestingly, the same relationship can be viewed as one of reward power and coercive power. For example, if a teacher obeys a principal through fear of punishment, it is coercive power; but if another teacher obeys in anticipation of a reward, it is reward power.

Legitimate power is the administrator's ability to influence the behavior of subordinates simply because of formal position. Subordinates acknowledge that the administrator has a right to issue directives and they have an obligation to comply. The greater the distance a directive is removed from the administrator's area of responsibility, the weaker the legitimate power. For example, a principal can insist that grades be computed and turned in to the office; it is not legitimate for the principal to order the teacher to change the grade.

Referent power is an administrator's ability to influence behavior based on subordinates' liking and identification with the administrator. The administrator with referent power is 
admired, respected, and serves as a role model. The source of referent power rests with the extraordinary personality and interpersonal skills of the individual.

Expert power is the administrator's ability to influence subordinates' behavior based on specialized knowledge and skill. Subordinates are influenced because they believe that the information and expertise held by the administrator are relevant, are helpful, and are things they themselves do not have. Expert power is a personal characteristic and does not depend on occupying a formal position of power.

A large portion of any administrator's time is directed as "power-oriented" behavior - that is, "behavior directed primarily at developing or using relationships in which other people are to some degree willing to defer to one's wishes" (Kotter, 1978, p. 27). The way administrators use one type of power can hinder or facilitate the effectiveness of other kinds.

Reward power is likely to produce positive feelings and facilitate the development of referent power, but coercive power has the opposite effect (Huber, 1981). Subordinates may view administrators who demonstrate expertise as having more legitimate power. Greene and Podsakoff (1981) state that expert power may be the most stable form of power. In one study, they found that changes in the reward structure of an organization increased the perceived use of coercive power and reduced the perceived use of reward, legitimate, and referent power of the administrator, but expert power remained stable.

Gary Yukl (1981) offers some guidelines to administrators for building and using each of the five kinds of power. The following display summarizes the probable outcomes of each form of power in terms of commitment, simple compliance, or resistance. 
Probable Subordinate Responses to Power

\begin{tabular}{|c|c|c|c|}
\hline Type of Power & Commitment & Simple Compliance & Resistance \\
\hline Referent & $\mathrm{XXX}$ & $\mathrm{XX}$ & $\mathrm{X}$ \\
\hline Expert & $\mathrm{XXX}$ & $\mathrm{XX}$ & $X$ \\
\hline Legitimate & $\mathrm{XX}$ & XXX & $X$ \\
\hline Reward & $X X$ & XXX & $\mathrm{X}$ \\
\hline Coercive & $X$ & $\mathrm{XX}$ & XXX \\
\hline \multicolumn{4}{|c|}{$\begin{array}{l}\mathrm{XXX}=\text { Most Likely } \\
\mathrm{XX}=\text { Less Likely } \\
\mathrm{X} \quad=\text { Least Likely }\end{array}$} \\
\hline
\end{tabular}

For example, the use of referent power is most likely to promote commitment, next most likely to result in simply compliance, and least likely to create resistance and develop alienation. Commitment is most likely with the use of referent and expert power; legitimate and reward power are most likely to promote a simple compliance; and coercive power will probably produce resistance and eventually alienation. Amitai Etzioni (1975) draws similar conclusions in his analysis of the consequences of using power in organizations.

Etzioni (1975) used the concept of power and subordinates' response to power, which he calls compliance, as the basis of a theory of organization. Here the focus is on organizational power. Etzioni's typology of power is based upon the means used to make individuals comply with organizational directives; he identifies three types of power: coercive, remunerative, and normative.

Coercive power depends on the actual or threatened application of physical sanctions. Remunerative power rests upon the management of material resources such as salaries, wages, 
bonuses, and fringe benefits. Normative power has its origins in the allocation and manipulation of symbolic rewards and sanctions such as honors, grades, and recommendations.

To each type of power Etzioni describes three reactions in terms of the intensity and direction of subordinate involvement. Involvement ranges along a continuum from positive through neutral to negative. Intense positive involvement is called commitment; intense, negative involvement is termed alienation; and mild involvement is referred to as calculation (Hoy and Miskel, 1996, p. 181).

Compliance is the relationship between the kinds of power applied to subordinates and their resulting involvement in the organization. Power and authority have been presented as the legitimate power of school systems. However, it is the political perspective that calls attention to the illegitimate, informal power that is inherent in school systems.

Politics is "individual or group behavior that is informal, ostensibly parochial, typically divisive, and above all, in the technical sense, illegitimate - sanctioned neither by formal authority, accepted ideology, nor certified expertise" (Mintzberg, 1983, p. 172). Politics are advanced by powerful individuals; however, the arena is populated by coalitions of individuals and groups. These individuals and groups are constantly bargaining among themselves to determine the distribution of power (Cyert and March, 1963).

Coalitions of influencers of school systems include, but are not limited to, teacher organizations, unions, parent-teacher associations, taxpayer groups, state departments of education, colleges and universities, professional organizations, media, and other special interest groups. Hoy and Miskel (1996) suggest that most of these groups are trying to bring their own interests and external power to bear on the activities of school systems. The inherent problem is 
developing plans and skills to achieve their desired outcomes when they function outside of official decision-making structure of the school system. Mintzberg (1983) notes that the impact of the external coalition on the organization varies dramatically, and he proposes a continuum of three external coalitions - dominated, divided, and passive.

A dominated external coalition is composed of one sole, powerful influencer or set of external influencers acting in concert. "In such cases the external coalition is so powerful that it dominates not only the internal coalition but also the board of education and the superintendent" (Hoy and Miskel, 1996, p. 187). In this instance the board and superintendent are tools or puppets for the external coalition. On occasion, a community issue can become so popular that a concerted effort by an organized group of external influencers can dominate, if left unchallenged, the policies and activities of a school system. Hoy and Miskel (1996) assert that dominate coalitions do not remain unchallenged; in fact, it seems only a matter of time until other groups and individuals will coalesce and act. Without a dominant external power coalition, the power system of an organization changes in fundamental ways. When the external coalition is divided among independent and competing individuals and groups of influencers, the organization is pushed in different directions as it attempts to respond to conflicting pressures.

The divided external coalition exists when a few different sets of influencers emerge such that there is a rough balance of influence among the conflicting groups. In many instances the balance is between conservative and progressive groups which results in the curriculum being the central focus of the attempts for control. Their power struggles are reflected on the board of education and inevitably spill over into internal coalitions within the school. Mintzberg (1983) 
asserts a divided external coalition often has the effect of politicizing the board as well as the internal coalition.

A passive external coalition is reached when the number of outside groups of external influencers continues to increase to the point where the power of each is diffused and limited (Hoy and Miskel, 1996, p. 188). This situation lessens the power of the external groups and power rests within the organization. Olsen $(1965,1968)$ suggests that apathy becomes the natural strategy for the large, dispersed groups. Thus, the external environment is relatively calm and stable when the influencers remain dispersed and passive.

There exists within a school system an internal group of influencers which form internal coalitions. These groups are often influenced and defined by the external coalitions. Hoy and Miskel (1996) suggest a dominated external coalition tends to weaken the internal coalition; a divided external coalition tends to politicize it; and a passive external coalition tends to strengthen it, often at the level of the central administration. Regardless of the external coalition, it is through the efforts of the internal coalition that the organization functions. Mintzberg (1983) describes five types of internal coalitions - personalized, bureaucratic, ideologic, professional, and politicized.

"The personalized internal coalition is one in which power is concentrated in the hierarchy of authority in the person of the chief executive officer, who rules the internal coalition. The superintendent, for example, controls the critical decisions and functions of the school in such a situation. There is little political game playing by insiders here" (Hoy and Miskel, 1996, p. 188). 
In the bureaucratic internal coalition, power is in the formal system of authority or the chain of command. The focus is on rules, regulations, and procedures. These controls seem to limit politics, yet political games tend to arise between staff as they construct budget allocations at the expense of others.

An ideologic internal coalition controls the school system when the ideology is so pervasive to dominate the organization. In this case the staff adopts the goals and objectives as their own. The fact that everyone shares the beliefs of the organization and thus everyone shares the power gives the appearance that the administrators have great power. Sergiovanni (1992, p. 104) suggests that "collegiality and egalitarianism prevail and internal politics is very limited because of the strong sharing of beliefs."

A professional internal coalition exists when the system of expertise dominates the organization. "Highly trained experts - professionals - surrender a great deal of power to their organizations and the institutions that train them" (Mintzberg, 1983, p. 81). Politics in this case is usually substantial because of the conflict between the internal systems of authority and expertise. "The professional internal coalition then is a playing field for a wide assortment of political games, yet politics is held in check by expertise” (Hoy and Miskel, 1996, p. 189).

Power rests solely on politics in a politicized internal coalition. In this coalition antagonistic, political games dominate the landscape and either substitute for or drive out legitimate power.

Hoy and Miskel (1996, p.190) state, "Politics is a fact of organizational life. Although there are powerful individuals, the political arenas of organizations are composed of coalitions of individuals and groups, which bargain among themselves to determine the distribution of 
resources. External as well as internal coalitions influence organizational politics. Political tactics are the bases of a system of political games played to resist authority, to counter resistance, to build power bases, to defeat opponents, and to change the organization. The system of politics typically coexists with the more legitimate systems of influence without dominating them, but power and politics generate conflict."

\section{CULTURE AND CLIMATE}

Bolman and Deal (1991, p. 231) discuss, "Some people argue that organizations have cultures; others insist that organizations are cultures." Schein (1992, p. 12) defines culture as "a pattern of shared basic assumptions that a group learned as it solved its problems of external adaptation and integration, that has worked well enough to be considered valid and therefore to be taught to new members as the correct way to perceive, think, and feel in relation to those problems.” Boyer (1995, p. 119) states, "The Basic School is, first, a community with shared goals. Second, it has a curriculum with coherence. The third priority brings it all together in a climate that promotes learning. Such a climate is sparked by great teachers who perform heroic acts every day, often working under difficult conditions." Deal and Kennedy (1982, p. 4) define culture as "the way we do things around here."

Terrence Deal (1985) suggests that effective schools have strong cultures with the following elements: (1) shared values and a consensus on "how we get things done around here," (2) the principal as a hero or heroine who embodies core values, (3) distinctive rituals that embody shared beliefs, (4) employees as situational heroes or heroines, (5) rituals of acculturation and cultural renewal, (6) significant rituals to celebrate and transform core values, 
(7) balance between innovation and tradition and between autonomy and control, and (8)

widespread participation in cultural rituals.

William Firestone and Bruce Wilson (1986) provide a framework for the organizational culture of schools. They suggest that the analysis of school culture can be addressed by studying its content, the expressions of culture, and primary communication patterns.

The symbols through which culture is expressed often help identify important cultural themes. Three symbols systems communicate the contents of a school's culture: stories, icons, and rituals. Stories are narratives that are based on true events, but they often combine truth and fiction. Some stories are myths; that is, they communicate an unquestioned belief that cannot be demonstrated by the facts. Other stories are legends that are retold and elaborated with fictional details (Hoy and Miskel, 1996, p. 137).

Two other items of school culture are icons and rituals. Icons (logos, mottoes, and trophies) are physical communication of culture. Rituals (ceremonies and rites) provide visible examples of what is important in the school system organization. School systems can be established from assemblies, staff meetings, sports, community activities, awards and trophies, and the general appearance of the schools in the system.

Organization culture is often described using metaphors. Steinoff and Owens (1989) use the following four metaphors to describe school culture:

- The family: The school is seen as a home or team and the principal is the parent or coach.

- The machine: The school is described as a smoothly running or rusty machine and the principal is a workaholic or slug.

- The cabaret: The school is a circus or Broadway show with the principal as the ringmaster or master of ceremonies. 
- The little shop of horrors: The school is unpredictable and a nightmare reminiscent of the French Revolution and the principal is a self-cleaning statute or a Jekyll and Hyde.

These metaphors can readily replace the school and principal with the school system and superintendent. Similarly, Deal and Wise (1983) use the metaphors of factories, jungles, and temples to describe schools with principals as CEOs, lion tamers, and gurus. The substitution of superintendent for principals is also applicable for school systems.

The analysis of schools in terms of culture calls attention to the symbolic nature of social interactions in schools (Bolman and Deal, 1991; Cunningham and Gresso, 1993). Bolman and Deal (1991) refer to the culture perspective as the "symbolic frame" for viewing organizations. They present the following assumptions about the nature of organizations and behavior:

- What is most important about events in organizations is not what has happened but what they mean.

- Events and meanings, however, are often unclear because events have different meanings for different people. Individuals use different schemas to interpret their experiences.

- Because events are typically ambiguous or uncertain, it is difficult to know what happened, why it happened, and what will happen next.

- The greater the ambiguity and uncertainty in events, the more difficult it is to use rational approaches in organizational analysis.

- Confronted with ambiguity and uncertainty, people create symbols and stories to resolve confusion and provide understanding. 
- Thus, for many organizational events, their importance rests with what they express rather than what is produced; secular myths, rituals, ceremonies, and sagas give people the meanings they seek.

The literature on organizational culture seems to say that much of what occurs in schools and school systems must be interpreted in the context of the organizations culture. Budgeting in the best of times is a difficult task. Relating budgeting to culture would indicate that developing a budget in times of fiscal hardship is devastatingly difficult unless the administration and board of education understand the culture of the schools and the school system.

Unlike organization culture, organization climate has generated much more research and was used by organization theorists to capture and describe the atmosphere of schools. B. H. Gilmer (1966, p. 57) defines organizational climate as "those characteristics that distinguish the organization from other organizations and that influence the behavior of people in the organizations." There has been consensus on the basic properties of organizational climate. Poole (1985) states the general consensus as follows:

- Organizational climate is concerned with large units; it characterizes properties of an entire organization or major subunits.

- Organizational climate describes a unit of organization rather than evaluates it or indicates emotional reactions to it.

- Organizational climate arises from routine organizational practices that are important to the organization and its members.

- Organizational climate influences members' behaviors and attitudes. 
School climate refers to employees' perceptions of the work environment of the school. It is influenced by the formal organization, informal organization, personalities, and leadership. The climate of a school may be described as the personality of the school.

A valuable conceptualization of school climate is the interaction among teachers described on a continuum from open to closed. Hoy and Miskel (1996) describe the distinctive feature of the open climate as its high degree of thrust and esprit and its low disengagement. In this climate both the teacher and principal are genuine in their behavior. The principal leads by example and the faculty is committed to the task of learning and cooperation with each other. "In brief, the behavior of both the principal and faculty is authentic" (Hoy and Miskel, 1996, p. 142).

The closed climate is virtually the opposite of the open climate. Thrust and esprit are low and disengagement is high. There is an appearance of everyone going through the motions. The principal manages by stressing routine trivia and busywork, and the teachers respond with minimal effort and little satisfaction. "The behavior of both principal and teachers is least genuine; in fact, inauthenticity pervades the atmosphere of the school" (Hoy and Miskel, 1996, p. 142).

Another conceptualization of climate examines the organizational health of schools. Matthew Miles (1969, p. 378) describes a healthy organization as one that "not only survives in its environment, but continues to cope adequately over the long haul, and continuously develops and extends its surviving and coping abilities." This description implies that the school deals effectively with outside interruptions effectively and continues to accomplish its goals and objectives. A healthy school is one in which the technical, managerial, and institutional levels are in harmony (Hoy and Miskel, 1996). 
A final conceptualization of climate discusses the continuum of control over pupils from humanistic to custodial. "The custodial orientation is the traditional school, which provides a rigid and highly controlled setting in which maintenance of order is primary" (Hoy and Miskel, 1996, p. 158). The climate of this school is rigid and autocratic. Power is unilateral and top down and students must accept the decisions of the faculty without question.

On the other hand, the model for the humanistic orientation is "the school conceived of as an educational community in which students learn through cooperative interaction and experience" (Hoy and Miskel, 1996, p. 158). In this model self-discipline takes the place for strict teacher control. The school atmosphere is democratic with two-way communication between teachers and pupils. The term "humanistic orientation" is used in the sociopsychological sense suggested by Erick Fromm (1948); it stresses the importance of the individual and the creation of an atmosphere that meets students needs.

The differing frameworks of culture and climate in the organization are useful to superintendents and boards of education when constructing annual financial allocations. One needs only to "follow the money" to ascertain the culture and climate philosophy of a school district.

\section{DESCRIPTIVE RESEARCH}

The purpose of survey research is to describe specific characteristics of a large group of persons, objects, or institutions (Jaeger, 1988). The point is to reconstruct accurately what took place during the time studied and explain why it did (Fraenkel and Wallen, 1990). A survey study is one type of descriptive research which may include documentary analysis (Van Dalen and Meyer, 1962). Survey research provides information and specific facts that describe a large 
group, the groups that are of interest are well defined, the researcher wants to know something about the present conditions of a group rather than something about what would happen if something was changed, and the most obvious way to secure the desired information would be to ask the right people (Jaeger, 1988). Fraenkel and Wallen (1990) describe descriptive research as studies that describe a given state of affairs as fully and carefully as possible.

Survey research is part of a larger category of inquiry that social scientists call field research. In a field study, the researcher does not do anything to the objects or subjects of research, except observe them or ask them to provide data. The research consists of collecting data on things or people as they are, without trying to alter anything. In fact, those who conduct field research often try to be as unobtrusive as possible, to minimize the effect of data collection on the objects or persons being studied. This is certainly the case in survey research. The more intrusive a survey, the lower the chances that it will accurately reflect real conditions (Jaeger, 1988).

Van Dalen and Meyer (1962) say that survey studies are used by education, government, and political organizations when they want to collect details of existing conditions. Generally, survey research deals with the incidence, distribution, and relationships of educational, psychological, and sociological variables. No experimental variables are manipulated. Some surveys are limited to describing the status quo, while others attempt to determine the relationships and effects occurring between the variables. In the latter case, we have what is called ex post facto research. In survey research the data are collected, and the researcher attempts to identify any effects that may exist and tries to explain how the effects are operating. 
A type of survey is a documentary survey, also known as documentary analysis.

"Documents and records may be dull reading to laymen, but researchers often unearth exciting and pertinent data from these sources. Documentary analysis . . is closely akin to historical research. Both ... examine existing records but historical research is primarily concerned with the more distant past and descriptive research with the present" (Van Dalen and Meyer, 1962, p. 211).

Three basic methods of collecting data are available to the survey researcher: mail surveys, telephone surveys and face-to-face interviews. Mail surveys have the distinct advantage of economy. Since transportation costs are a major expense in most face-to-face interview surveys, mail surveys are almost always less expensive. Telephone interview surveys also eliminate transportation costs, but phone calls are usually more expensive than distribution of questionnaires through the mail, particularly when the survey sample is widely dispersed. In some survey projects, budget restrictions make mail surveys the only feasible choice (Jaeger, 1988).

Jaeger (1988) states that complex issues can be examined through a mail survey only when the survey population is composed of specialists with a common background and a natural interest in the topic. Surveys may be comprehensive or very focused; may cover several states or cover one city; and may gather data from every person in the population to be studied or from a representative sample. The data may cover a wide variety of related factors or only a few factors. The problem to be studied determines the scope of the survey (Van Dalen and Meyer, 1962). 
Tuckman (1978, p.10) says "Nonetheless, when properly constructed and when employed within proper design, questionnaire and interview approaches [and documentary analysis] may be used to great advantage."

\section{SUMMARY}

This chapter includes a review of literature concerning budget, power and politics, culture and climate, and descriptive research methodology. In education the major planning tool should be the budget. It is the factual measurement of resource allocation alignment with the goals and objectives of a school system. A hastily prepared budget may be catastrophic fiscally, resulting in deficit spending, and will not adequately finance the goals of the organization.

Power and politics and culture and climate describe and discuss the forces at play in the education arena both within and outside the school system. It also describes the personality traits of the organization from open to closed and characteristics that distinguish one school system from another.

Descriptive research is the research method used when document analysis is critical to the study. Descriptive research is used to describe the characteristics of a large group of persons and institutions. One important feature of the survey is its longitudinal design. The point is to reconstruct accurately what took place during the time studied.

The research questions used in this study reflect the power and politics and culture and climate characteristics that distinguish one school system from another in West Virginia.

Descriptive research is used to look at the budget deficits as reported by individual counties from school years 1987-1988 to 1996-1997 in relationship to changes in the school aid formula after the enactment of reform legislation such as Senate Bill 14. 


\section{CHAPTER 3}

\section{METHOD AND RESEARCH DESIGN}

This study utilized a descriptive research design. Data were collected from two sources: (1) deficit, enrollment, and personnel data were provided by the West Virginia Department of Education and (2) all fifty-five county superintendents and treasurers were surveyed to determine the frequency and cause of budget deficits.

The researcher requested access to the deficit, enrollment, and personnel data collected by the West Virginia Department of Education. These data were analyzed and compiled to describe the counties experiencing budget deficits and the underlying causes which contributed to the deficits as reported on the annual financial statements for fiscal years ended June 30, 1988 through June 30, 1997.

\section{SUBJECTS}

The subjects selected for response to the survey instrument were the fifty-five county boards of education superintendents and treasurers ( $\mathrm{n}=55$ superintendents; $\mathrm{n}=55$ treasurers). They were selected because of their active role in budget development and operation during the time when the local boards of education were experiencing an increasing frequency of budget deficits as reported on their annual financial statements. Their response to the questions included 
in the survey instrument assisted the researcher to determine the contributing factors to budget deficits experienced by the fifty-five county boards of education in West Virginia.

\section{INSTRUMENT}

The survey instrument was developed and piloted by the researcher with assistance from staff of the West Virginia Department of Education, Division of Administrative Services. The survey instrument was mailed with a cover letter to each of the fifty-five county superintendents and treasurers for completion. The final version had six questions plus an explanatory area for anecdotal comments. Additionally, the respondents were requested to provide any comments which they felt were relevant to the survey and were contributing factors to budget deficits between June 30, 1988 and June 30, 1997. The results of the study enabled the researcher to glean what the superintendents and treasurers viewed as contributing factors that led to budget deficits in their respective counties.

\section{PROCEDURE}

The superintendents and treasurers were asked to return the completed instruments to the researcher. Stamped and pre-addressed envelopes were provided for expediency in returning the questionnaire. Less than eighty percent, or forty-four responses, from the county superintendents would result in a second mailing or a telephone inquiry. Forty-five, or eighty-two percent, of the superintendents initially responded to the survey. The follow-up telephone inquiry resulted in one hundred percent response.

Less than eighty percent, or forty-four responses, from the county treasurers would result in a second mailing and telephone follow-up. One hundred percent of the treasurers responded. 


\section{DATA ANALYSIS}

Data were obtained from the West Virginia Department of Education and were analyzed using descriptive statistics. The number, frequency of occurrence, and percentage of county boards of education reporting deficits were studied. Data from June 30, 1988, through June 30, 1997, were analyzed and compared. The information collected by the survey was tabulated by category as much as possible. The data were reported by percentage and category to enable analysis and identification of the common factors present in county boards of education reporting deficit spending.

These activities revealed a series of common factors which were present in data from the West Virginia Department of Education and reported by county board of education superintendents and treasurers as responses to the questionnaire. These common factors revealed a description of the cause of budget deficits as reported by county boards of education in West Virginia between June 30, 1988, through June 30, 1997. 


\section{CHAPTER 4}

\section{RESEARCH FINDINGS}

An analysis of data collected for this study was reported in this chapter. Results of the data analysis are reported to describe why increasing numbers of county boards of education experienced budget deficits since the enactment of Senate Bill 14. Six major research questions were addressed:

1. To what extent did the reduction of personnel funded in the formula affect the increased incidence of budget deficits?

2. What steps did county boards of education take to avoid deficit spending?

3. Did county boards of education experience a budget deficit prior to 1988 ?

4. What policies and practices are counties continually implementing to avoid a budget deficit?

5. If closure and consolidation of schools were used to avoid deficit spending, what was the impact on the budget?

6. What was the effect of continuing budget deficits on the academic and extracurricular programs?

The deficit, personnel, and enrollment data described under primary information were collected by the West Virginia Department of Education and provided to the author for analysis. 
All fifty-five county board of education superintendents and treasurers were surveyed by mail with a 100 percent response. The opinions and comments of all fifty-five superintendents and treasurers surveyed are described in answer to each research question. Data collected by the department are also described in answer to some of the research questions.

\section{PRIMARY INFORMATION}

Several bills were enacted into law by the West Virginia Legislature in 1988, 1989, and 1990 that changed the provisions of personnel funding in the school aid formula. The purpose of these bills was to force counties to reduce the number of personnel in the public school system more rapidly than the decline in either net or adjusted enrollment (Senate Bill 14, 1988; House Bill 2326, 1989; House Bill 101, 1990; and Senate Bill 8, 1990). Those legislative mandates impacted the operating budgets of every county board of education in West Virginia. Table 1 presents a comparison of the data from school year 1987-1988 and school year 1996-1997 for personnel from all funding sources, professional personnel, service personnel, net enrollment and adjusted enrollment.

As illustrated in Table 1, between 1987-1988 and 1996-1997, there was an eight percent decrease in the number of personnel employed from all funding sources in the fifty-five county boards of education. 


\section{Table 1}

Comparison of Total Personnel Employed (All Funding Sources) and Enrollment Between 1987-1988 and 1996-1997 School Years

\begin{tabular}{|l|c|c|c|c|}
\hline \multicolumn{1}{|c|}{$\begin{array}{c}\text { Personnel \& } \\
\text { Enrollment }\end{array}$} & \multicolumn{2}{|c|}{$\begin{array}{c}\text { School Year } \\
\mathbf{1 9 8 7 - 1 9 8 8}\end{array}$} & $\begin{array}{c}\text { Increase/ } \\
\text { (Decrease) }\end{array}$ & $\begin{array}{c}\text { Percent } \\
\text { Change }\end{array}$ \\
\hline All Personnel & $44,415.34$ & $38,101.44$ & $(3,313.90)$ & -8.00 \\
\hline Professional & $26,361.49$ & $24,394.55$ & $(1,966.94)$ & -7.46 \\
\hline Service & $15,053.85$ & $13,706.89$ & $(1,346.96)$ & -8.95 \\
\hline Net Enrollment & $333,962.00$ & $303,405.85$ & $(30,556.15)$ & -9.15 \\
\hline $\begin{array}{l}\text { Adjusted } \\
\text { Enrollment }\end{array}$ & $442,176.00$ & $412,256.85$ & $(29,919.15)$ & -6.77 \\
\hline
\end{tabular}

The number of personnel from all funding sources has not decreased at any greater rate than the decrease in enrollment. The changes enacted by the West Virginia Legislature should have caused a personnel reduction greater than the decrease in enrollment. The adjusted enrollment decrease of 6.77 percent was less than the decrease in net enrollment of 9.15 percent as presented in Table 1. (See Appendix for Tables A-1, A-2, A-3, A-4, and A-5 for individual county data.)

Comparing the percentage of decrease for personnel employed from all funding sources in Table 1 with the percent of decrease of personnel allowed and funded in the school aid formula in Table 2 demonstrates that the greatest reduction of personnel has occurred in those personnel funded within the school aid formula. 
Table 2

Comparison of Personnel Allowed in the Formula Between

School Years 1987-1988 and 1996-1997

\begin{tabular}{|l|r|r|r|l|}
\hline & \multicolumn{2}{|c|}{$\begin{array}{c}\text { School Year } \\
\text { Personnel }\end{array}$} & \multicolumn{1}{|c|}{$\begin{array}{l}\text { Increase/ } \\
\text { Decrease }\end{array}$} & $\begin{array}{l}\text { Percent } \\
\text { Change }\end{array}$ \\
\hline $\begin{array}{l}\text { All } \\
\text { Personnel }\end{array}$ & $39,396.227$ & $35,077.737$ & $(4,318.49)$ & -10.96 \\
\hline Professional & $24,593.280$ & $21,856.180$ & $(2,727.10)$ & -11.12 \\
\hline Service & $14,802.947$ & $13,221.557$ & $(1,581.39)$ & -10.68 \\
\hline
\end{tabular}

The 10.96 percent reduction of personnel allowed and funded in the school aid formula (see Table 2) is greater that the 8.00 percent reduction of personnel employed and funded from all funding sources available to county boards of education. (See Appendix for individual county data.)

Table 3 represents a comparison of the number of county boards of education reporting a budget deficit on their annual financial statement from school year 1987-1988 through 19961997. (See Appendix for Table A-9). 
Table 3

County Boards With Deficit Unreserved Fund Balances

General Current Expense Fund

At June 30, 1988 and 1997

\begin{tabular}{|c|c|c|c|}
\hline \multirow[b]{2}{*}{ County } & \multicolumn{2}{|c|}{ Fiscal Year Ended } & \multirow{2}{*}{$\begin{array}{l}\text { Increase/ } \\
\text { (Decrease) }\end{array}$} \\
\hline & 6-30-1988 & 6-30-1997 & \\
\hline Berkeley & $(141,768)$ & $1,299,504$ & $1,441,272$ \\
\hline Clay & 6,381 & $(180,410)$ & $(186,791)$ \\
\hline Doddridge & 463,303 & $(107,355)$ & $(570,658)$ \\
\hline Gilmer & $(173,209)$ & 122,715 & 295,924 \\
\hline Grant & 204,907 & $(55,380)$ & $(260,287)$ \\
\hline Lewis & 996,442 & $(796,518)$ & $(1,792,960)$ \\
\hline Lincoln & 342,169 & $(254,021)$ & $(596,190)$ \\
\hline Mingo & 317,379 & $(2,377,448)$ & $(2,694,827)$ \\
\hline Monroe & 254,536 & $(400,501)$ & $(655,037)$ \\
\hline Preston & $(22,452)$ & 189 & 22,641 \\
\hline Ritchie & 4,460 & $(449,582)$ & $(454,042)$ \\
\hline Summers & 142,353 & $(83,662)$ & $(226,015)$ \\
\hline Taylor & $(39,530)$ & 525,015 & 564,545 \\
\hline Upshur & $1,712,197$ & $(228,239)$ & $(1,940,436)$ \\
\hline Wetzel & $(58,574)$ & 623,562 & 682,136 \\
\hline Total & $4,008,594$ & $(2,362,131)$ & $(6,370,725)$ \\
\hline $\begin{array}{l}\text { Number } \\
\text { with deficits }\end{array}$ & 5 & 10 & 5 \\
\hline
\end{tabular}

In most cases, when funds in addition to the school aid formula are not available, county boards of education have incurred budget deficits. Data presented in Table 3 identify five county boards of education that incurred budget deficits in 1987-1988 and ten county boards of 
education reporting budget deficits in 1996-1997. Additionally, as reported in Table A-9, as many as seventeen county boards of education experienced budget deficits in the intervening school years between 1987-1988 and 1996-1997. Tables A-10 and A-11 provide details on which county boards of education had excess levies in 1987-1988 and 1996-1997. An excess levy is a tax levy approved by the voters to enable the county school district to have revenue in excess of the amount provided within the school aid formula. The revenue from the excess levy is designed to provide programs and services in addition to those provided by the school aid formula. The funds derived from an excess levy, in most cases, are sufficient to minimize the reduction of school aid revenue because the levy is based on the assessed valuation of property within a county and the formula is based on the student population of a county. The five districts reporting a budget deficit in 1987-1988 had an excess levy in place. Of the ten districts reporting a deficit at the end of 1996-1997, six had an excess levy in place and four did not.

\section{RESEARCH QUESTION 1}

To what extent did the reduction of personnel funded in the formula affect the increased incidence of budget deficits?

The data included in Table 4 were derived from the responses of the fifty-five superintendents and treasurers. 
Table 4

Reduction of Personnel Funded as a Cause

of Increased Incidence of Budget Deficits

\begin{tabular}{|l|c|c|}
\hline \multicolumn{1}{|c|}{ Impact } & Superintendent & Treasurer \\
\hline Major Factor & $67 \%$ & $65 \%$ \\
\hline Moderate Factor & $27 \%$ & $29 \%$ \\
\hline Not at all & $6 \%$ & $6 \%$ \\
\hline Total & $100 \%$ & $100 \%$ \\
\hline
\end{tabular}

Sixty-seven percent of the superintendents and sixty-five percent of the treasurers viewed the reduction of personnel allowed and funded in the school aid formula as a major factor contributing to the increased incidence of budget deficits in their respective county school districts.

Twenty-seven percent of the superintendents and twenty-nine percent of the treasurers viewed the reduction of personnel allowed and funded in the school aid formula as a moderate factor contributing to the increased incidence of budget deficits in their school districts.

Six percent of the superintendents and six percent of the treasurers responded that the reduction of personnel allowed and funded in the school aid formula had no impact on the increased incidence of budget deficits in their counties.

\section{RESEARCH QUESTION 2}

What steps did the county board of education take to avoid deficit spending?

The majority of the respondents reported implementing personnel reductions in force and personnel transfers until the formula allocations were met. Many reported the consolidation of 
schools, the reduction of programs, and reduced services as a method implemented to align staff employed with the number allowed in the formula.

The data included in Table 5 were derived from the responses of the county superintendents and treasurers.

Table 5

Steps Taken by County Boards of Education to Avoid Deficit Spending

\begin{tabular}{|l|c|c|}
\hline \multicolumn{1}{|c|}{ Steps Taken } & Superintendent & Treasurer \\
\hline Reduce Professional Staff & $76 \%$ & $72 \%$ \\
\hline Reduce Service Staff & $74 \%$ & $70 \%$ \\
\hline Reduce Administrative Staff & $74 \%$ & $72 \%$ \\
\hline Close/Consolidate Schools & $58 \%$ & $58 \%$ \\
\hline Defer Expenditures & $54 \%$ & $58 \%$ \\
\hline No action taken & $1 \%$ & $0 \%$ \\
\hline
\end{tabular}

The reduction of personnel as reported by the respondents to the survey is supported by data presented in Appendix A, Table A-3 which shows a decrease of 8.00 percent in personnel employed, all funding sources, between school years 1987-1988 and 1996-1997. Table A-4 shows a decrease of 7.46 percent in the number of professional personnel employed from all funding sources, between school years 1987-1988 and 1996-1997. Table A-5 presents a decrease of 8.95 percent in the number of service personnel employed, all funding sources, between school years 1987-1988 and 1996-1997.

The majority of the superintendents and treasurers reported the most frequent action taken to avoid deficit spending was the reduction of professional, service, and administrative staff. 
The next course of action chosen by county boards of education to avoid deficit spending was to close and/or consolidate existing schools along with deferring other current expenditures. Only one county board, as reported by the superintendent, decided to take no action to avoid deficit spending.

The fifty-five superintendents and treasurers provided the following specific examples of actions taken by county boards of education to align the number of personnel employed to the number allowed and funded in the formula.

1. Employ only the number of personnel allowed and funded in the school aid formula.

2. The use of substitute personnel was greatly reduced and monitored.

3. The number of administrator, service, and instructional positions was reduced and the work distributed to other staff.

4. Improved purchasing procedures by implementing cooperative purchasing within RESAs and the increased use of competitive bidding for commodities.

5. The budget was constantly monitored and some expenditures were deferred, especially in the area of maintenance of buildings.

6. Many county boards implemented state of the art HVAC systems, reduced the number of telephone lines, bid telephone carriers, and competitively bid the purchase of natural gas.

7. Respondents reported the elimination of non-essential travel and the reduction of field trips by students. 


\section{RESEARCH QUESTION 3}

Did county boards of education experience a budget deficit prior to 1988?

The data presented in Table 6 were derived from the responses of the county superintendents and treasurers.

\section{Table 6}

Number of County Boards of Education Experiencing Budget Deficits Prior to 1988 as Reported by Superintendents and Treasurers

\begin{tabular}{|l|c|c|}
\hline \multicolumn{1}{|c|}{ Deficit } & Superintendent & Treasurer \\
\hline No & 50 & 50 \\
\hline Yes & 5 & 5 \\
\hline
\end{tabular}

Prior to 1988 , as reported by county superintendents and treasurers, only five county boards of education experienced budget deficits.

\section{RESEARCH QUESTION 4}

What policies and practices are counties continually implementing to avoid a budget deficit?

The data included in Table 7 were derived from the responses of the county superintendents and treasurers. 
Table 7

County Board of Education Policies and Practices Continually

Implemented to Avoid Budget Deficits

\begin{tabular}{|l|c|c|}
\hline \multicolumn{1}{|c|}{ Policies/Practices } & Superintendent & Treasurer \\
\hline $\begin{array}{l}\text { Maintain Staff Level as } \\
\text { Funded by Formula }\end{array}$ & $52 \%$ & $52 \%$ \\
\hline $\begin{array}{l}\text { Staff Level Above Formula } \\
\text { Using Excess Levy }\end{array}$ & $47 \%$ & $49 \%$ \\
\hline Close/Consolidate Schools & $41 \%$ & $36 \%$ \\
\hline Defer Expenditures & $34 \%$ & $38 \%$ \\
\hline
\end{tabular}

Fifty-two percent of the superintendents and treasurers reported the most prevalent practice implemented to continually avoid a budget deficit was to maintain staffing levels at the level allowed and funded in the school aid formula. The use of excess levy funds to maintain staffing levels above the number allowed and funded in the school aid formula was the course of action pursued by forty-seven percent of the superintendents and forty-nine percent of the treasurers responding to this question. Also, forty-one percent of the superintendents and thirtysix percent of the treasurers reported the action taken by the county board of education was to close and/or consolidate schools to avoid future budget deficits. Finally, the strategy of deferring expenditures to continually avoid a budget deficit was selected by thirty-four percent of the superintendents and thirty-eight percent of the treasurers.

County boards of education are continually monitoring the following practices to avoid a budget deficit:

1. Altered purchasing procedures by leasing services, competitive bidding, and expenditure approval by treasurer and superintendent. 
2. Regular monitoring and reporting on the status of the annual adopted budget.

3. Maintain or limit hiring additional positions not funded within the school aid formula.

4. Continue to defer maintenance expenditures.

\section{RESEARCH QUESTION 5}

If closure and consolidation of schools were used to avoid deficit spending, what was the impact on the budget?

Table 8

Impact of Closure and Consolidation to Avoid Deficit Spending

\begin{tabular}{|l|c|c|}
\hline $\begin{array}{c}\text { Impact of Closure or Consolidation } \\
\text { on Deficit Spending }\end{array}$ & Superintendent & Treasurer \\
\hline Deficit Spending Did Not Occur & 21 & 19 \\
\hline Deficit Spending Did Occur & 8 & 9 \\
\hline No Impact & 4 & 3 \\
\hline
\end{tabular}

Twenty-one of the fifty-five county superintendents and nineteen of the treasurers who responded reported successfully using school closure or consolidation to avoid deficit spending. Eight of the county superintendents and nine of the treasurers reported experiencing deficit spending despite implementing the process of school closure or consolidation to avoid deficit spending. Four of the superintendents and three of the treasurers responded that the implementation of school closure and consolidation had no direct relationship on the occurrence of deficit spending as reported on the annual financial report. 
The following statements are some examples of expenditure savings or increases as reported by the superintendents and treasurers who used closure and consolidation of schools to avoid deficit spending:

"Closing and consolidating schools has saved a lot of money spent on personnel. Closure and consolidation requires fewer personnel per student to deliver the curriculum."

"We were able to end our first year after consolidation without a deficit. The consolidation allowed us to cut professional personnel to within the formula and we are closer to the funded amount of service personnel than ever. This savings, however, will only offset a portion of the added cost of maintaining and operating the new school facility. Utilities are the major factor."

"Consolidation reduced the number of employees and utility costs."

"Expenditures for utilities were reduced, maintenance costs were avoided, and potential duplicate administration costs were eliminated."

"Consolidation assisted in keeping the number of employees closer to the state formula. Utility costs and insurance were reduced as was maintenance for older buildings."

"Personnel, utilities, split grade allocation, and maintenance costs were reduced."

"Despite the savings in personnel from a major consolidation, the county experienced a deficit. The deficit would have been much worse without the consolidation. Approximately twenty positions were eliminated at one time, which would have been most difficult without consolidation. However, there were several unanticipated expenditures associated with building the school that were not covered by the SBA grant. Over $\$ 600,000$ was spent from local funds for such things as land purchase, equipment, blacktopping, landscaping, and change orders." 
“Transportation costs stayed about the same with consolidation, but utility costs soared as the new school used more electricity and less natural gas. The HVAC system was much better than the closed schools but it was very expensive to maintain and used more energy. None of the closed schools had air conditioning. Maintenance and utility costs continue to run higher than before consolidation, but savings accrued in personnel. Many more instructional and cocurricular offerings were available even with a reduced staff."

\section{RESEARCH QUESTION 6}

What is the effect of continuing budget deficits on the academic and extracurricular programs?

Table 9 represents the impact of continuing budget deficits most frequently reported by the respondent superintendents and treasurers.

Table 9

\section{Continuing Budget Deficits Effect on Academic and Extracurricular Programs}

\begin{tabular}{|l|c|c|}
\hline \multicolumn{1}{|c|}{ Effect } & Superintendent & Treasurer \\
\hline Reduction of Supplies & 13 & 12 \\
\hline Reduction of Equipment & 6 & 8 \\
\hline Decreased Course Offerings & 13 & 11 \\
\hline $\begin{array}{l}\text { Reduced Funds for Extracurricular } \\
\text { Activities }\end{array}$ & 6 & 8 \\
\hline $\begin{array}{l}\text { Reduced Funds for Curricular and } \\
\text { Extracurricular Salaries and } \\
\text { Transportation }\end{array}$ & 6 & 8 \\
\hline
\end{tabular}

The most frequent effect of continuing budget deficits as reported by the superintendents and treasurers was the reduction of instructional supplies for the students purchased by the local 
board of education for curricular offerings. Along with the reduction of instructional supplies thirteen superintendents and eleven treasurers reported the necessity to reduce course offerings within the curriculum especially at the secondary level.

Six of the superintendents and eight of the treasurers reported the reduction of the purchase of instructional equipment related to the course offerings as an action taken because of continuing budget deficits.

The reduction of expenditures for extracurricular activities was reported by six of the superintendents and eight of the treasurers. Along with a reduction of funds for extracurricular offerings six of the superintendents and eight of the treasurers reported reducing funding for transportation and salaries for extracurricular activities.

Some additional areas of reduced spending resulting from continuing budget deficits as reported by the respondents to the questionnaire were: reduction of administrative and support personnel in the schools, reduction of instructional personnel, reduced the number of extracurricular contracts and reduced the amount of pay for extracurricular contracts, decreased the number of elective and advanced placement course offerings, deferred the purchase of textbooks, increased the participation fees for extracurricular activities, and increased class size at the secondary level.

\section{ANECDOTAL DATA}

As a part of the survey the researcher asked respondents to provide any comments relevant to this survey and the contributing factors to budget deficits between June 30,1988 , and June 30, 1997. 
The following comments were gleaned from the responses to the questionnaire as mentioned most frequently by the superintendents.

"Continual reduction in force and transfers are unsettling on the educational community. It does not create a climate of trust regardless of how well you explain the situation. In essence, a reduction in force is firing someone purely for financial reasons. I have followed this process each year I have been a superintendent. The older I get, the harder it gets to comply."

"The service personnel ratios used to allow for special education students with the 34/1000 adjusted enrollment. Now almost all counties are caught by the net enrollment ratio. Our biggest staffing problems are low incident special education that require aides (BD, SMI, MMI, LD, etc.) where there may be a ratio of two adults per student or up to a ratio of two adults per twelve students. Kindergarten also requires aides for more than ten students so net enrollment really hampers staffing. The same is true for professional staff to some extent. Low incidence special education and vocational classes should be accounted for separately from the overall staffing ratios."

"Senate Bill 14 was the legislation that most directly led counties into deficit. The shrinking of the personnel numbers through 1995 could not be accomplished fast enough for most systems. Lowering of special education numbers and consolidation of schools was not keeping pace with the lowering of the net caps on personnel. Unfunded mandates kept coming until about 1994. The cuts made by the Governor in several years following S.B. 14 thrust many counties, especially those without excess levies, into deficit. All these issues coupled with some excalating costs like PEIA, BRIM, some utilities, and deficiencies in the amount of SBA grants were too much for the counties to embrace." 
"The reduction of fifty-five professional personnel per one thousand students to fiftythree and one-half per thousand was truly the single biggest financial blow to West Virginia schools."

“The philosophy of providing special education students everything they want or need, although most honorable, sets up situations where county boards must hire personnel whether or not they have budget funds to pay for them."

"The decreasing enrollment causes fewer staff positions provided but the student loss does not occur in a manner that allows for staff reduction."

"The class size caps create situations where an additional one student can require the employment of an additional teacher."

"The class size limit in grades K-6 restricts the budget. We have had to add staff when new students enter school after the first day. We are not always able to transfer students to schools with lower class enrollment."

"Our county was in deficit for three years. We have reduced all areas in the budget to get out of deficit. The reductions have hurt the quality of the programs."

The following responses were the most frequently mentioned by the treasurers.

"The reduction of personnel as a result of S.B. 14 and the pupil-teacher ratio in grades K6 are the greatest contributors to deficit spending."

“Changes brought about by Senate Bill 14 have not all been bad. In our county, a great deal of waste has been eliminated. The decreases in funding have forced our board and administration to concentrate on areas essential to educating students and to budget dollars into those areas. There are, however, problems that have surfaced due to declining enrollment, the 
sparsity of our population, and lack of an excess levy. We are to the point where, to avoid deficit spending, essential programs may have to be cut. We have already trimmed the Central Office Staff to the point where employee turnover is very high. Our only audit findings state they are due to lack of staff. There is also no money to set aside for contingencies. One extenuating circumstance could cause us to be in a deficit situation. We have reached the point in Calhoun County that if we keep the personnel within the formula, to avoid a deficit, it is going to affect the quality of the education we are able to provide."

"The formula changes in pupil-teacher ratio make it very difficult to maintain a balanced budget."

"Senate Bill 14 was a primary contributor to the advent of budget deficits by county school boards. I believe many counties did not foresee or pay heed to the financial impact of the Bill. Accordingly, budget cuts, expenditure reductions, and informed decisions were not made as necessary."

\section{SUMMARY OF FINDINGS}

\section{General Information}

The review of the literature indicated that budgeting is a management problem, not an accounting problem. The guiding principle must be "thinking it through before crunching the numbers" (Finney, 1993, p. 10). Educators are generally smart, aggressive, and results oriented. When given a problem in the teaching and learning arena they will attack it with vigor. However, when faced with the task of budget preparation, educator behavior appears to be irrational. Oftentimes this is a result of the school system not having in place a strong budget planning method and model. Powerful budgeting requires a behavioral approach to a process 
that develops the best possible information, encourages excellence throughout the school system, and overcomes the inherent problems of budgeting.

Budgeting as used by county boards of education in West Virginia means the financial plan for the period of a year. Budget always refers to annual budget coinciding with the fiscal year and commencing on July 1 and ending on the next June 30. Many county boards of education have a strategic plan. All boards of education have an annual budget. All systems have goals, objectives, and expectations, even if they are not formally written down.

Although each county school system has its own set of problems and parameters of operations characterized by their differences and similarities, a large body of principles applies to every school system. Some school systems do no formal budget planning while others seem to plan continuously. However, most systems fall somewhere in the middle. Similar approaches and techniques can be applied beneficially in almost any school system in the quest for budgetmaking as long as the systems adapts the techniques and processes to its own specific situation.

\section{Summary of Findings for Each Research Question}

\section{Research Question 1. To what extent did the reduction of personnel in the formula} affect the increased incidence of budget deficits? Based on the analysis of the data presented in Table 4, sixty-seven percent of the superintendents and sixty-five percent of the treasurers reported that the reduction of personnel funded in the formula was a major factor in the increased incidence of budget deficits. Also, twenty-seven percent of the superintendents and twenty-nine percent of the treasurers reported the reduction of personnel funded in the formula was a moderate factor in the increased incidence of budget deficits. 
The analysis of the responses revealed that the vast majority of the respondents believe the reduction of personnel funded within the school aid formula to be a common factor leading to county boards of education reporting budget deficits. It is interesting to note that only six percent of the superintendents and treasurers believe the reduction of personnel funded was not at all a common factor leading to county boards of education reporting financial budget deficits.

An analysis of the data and the survey of the superintendents and treasurers revealed the reduction of personnel funded to be a significant and common factor in the increased incidence of budget deficits.

One district superintendent enumerated the following specific actions:

1. Eliminated fifty professional and twenty-five service personnel positions

2. Consolidated three schools

3. Eliminated six bus runs and consolidated others

4. Consolidated service personnel positions

5. Reduced employment term of several twelve month (261 day) service personnel

6. Reduced administrative staff at county office and assistant principals

7. Equipped large buses with lifts for special education students and eliminated small special education buses

8. Did not advertise or repost personnel vacancies that were not essential

9. Wrote grants to support some personnel

10. Contracted some services for transportation, substitute calling, and maintenance

11. Eliminated some elective course offerings at the secondary level

12. Monitored funding formula and adjusted enrollment 
Another county superintendent summarized the action taken as a result of the reduction of the number of personnel funded to avoid deficit spending: "A large number of professional and service personnel positions were eliminated. These positions came from the reduction of essential administrative positions, elimination of elective programs, fewer custodians with multiple buildings to care for, fewer secretaries at a time when more and more secretarial help is needed."

\section{Research Question 2. What steps did county boards of education take to avoid deficit}

spending? The superintendents and treasurers reported the reduction of staff was the action most frequently taken by county boards of education to avoid deficit spending followed closely by the closure and consolidation of schools and deferred expenditures.

Fifty-eight percent of the superintendents and treasurers reported closure and consolidation of schools as a step taken by county boards to avoid deficit spending. Appendix A, Table A-14 supports this finding by showing a reduction of 234 , or 21.25 percent, schools between school years 1987-1988 and 1996-1997.

When surveyed, one county superintendent listed the following actions taken by the board of education to avoid a budget deficit:

1. Sold surplus property

2. Sold board office and moved into a closed school

3. Centralized food service accounting and purchasing

4. Joined with RESA to competitively bid products

5. Became a licensed behavioral health center to enhance revenue and provide extra services 
6. Better management of Medicaid reimbursements

7. Used in-lieu of transportation payments to curb requests for new bus service

8. Reduced staff travel budget

9. Conducted utility audits

10. Did not replace any vehicles other than buses for an eight-year period

11. Rented some surplus property to qualified agencies

12. Postponed maintenance and improvement projects for schools

13. Reduced employment terms of several personnel with greater than 200-day contracts

14. Reduced the number of board meetings per month

15. Reduced the number of itinerant teachers

16. Provided incentives to schools for good attendance - part of state aid based on ADA (Average Daily Attendance)

17. Implemented dropout prevention programs to maintain enrollment

18. Maintained or increased enrollment by starting pre-school programs

19. Limited curricular and extracurricular trips and passed some costs to schools

20. Reduced support for athletics

21. Reduced community education and after-school programs

22. Eliminated full-time athletic director

In response to the questionnaire only one superintendent and none of the treasurers responded that the county board of education took no action to avoid deficit spending. 


\section{Research Question 3. Did county boards of education experience a budget deficit prior}

to 1988? Based on the analysis of the data and confirmed with data from the West Virginia Department of Education, fifty counties did not experience a budget deficit prior to 1988. Five county boards of education did experience a budget deficit prior to 1988 .

One county treasurer reported that while the county board of education did not experience a budget deficit prior to 1988, "There were some years in which the county board of education was close to deficit spending during the term of office of Governor Rockefeller. This was attributed to the reduction of state aid enacted by the governor."

One superintendent responded that the county board of education had experienced a budget deficit in 1976 as a result of the new construction of a bus garage with cost overruns that contributed to a deficit of $\$ 80,000$.

Another superintendent and treasurer reported incurring a budget deficit in 1983 predicated by the action of the superintendent and board of education members attempting to fulfill school building renovation and construction promises made to the citizens of the county. The county spent the proceeds of a $\$ 16.7$ million bond issue plus all interest accruing to the bond fund and found the amount of money available from the bond sale to be insufficient to complete all of the projects in the bond call. The superintendent and board then supplemented the bond fund with general current expense money to complete the projects thus causing the deficit.

The county board of education superintendents and treasurers that reported a deficit prior to 1988 attributed the deficit to decisions made by the superintendent and board of education members related to under-funded construction projects attempted by the school district. There 
was no reference to reform legislation as a contributing factor to the incidence of budget deficits incurred prior to 1988 .

\section{Research Question 4. What policies and practices are counties continually}

implementing to avoid a budget deficit? Based on the analysis of the data in Table 7 over half, or fifty-two percent, of the counties are attempting to maintain personnel staffing levels at the number allowed and funded in the school aid formula. Districts are staffing personnel in their county school systems above the number allowed in the formula using revenue generated from the proceeds of an excess levy, closing and consolidating schools, and deferring expenditures.

The superintendent and treasurer of one county presented the following practices implemented by their county to continually avoid deficit spending:

1. Acquisition of grants

2. Preventive maintenance program for school buses

3. Contracted services where possible (transportation, lawn service, and Heating Ventilation and Air Conditioning service)

4. Reducing employment terms as low as possible for principals, secretaries, custodians, and coaches

5. Performing energy audits and monitoring of building temperatures

6. Implementing in lieu of transportation payments to students

7. Implement new programs that have a funding stream outside current revenues

8. Reduce the use of professional and service substitutes

9. Careful monitoring of monthly revenues and expenditures 
One superintendent responded, "If we do not have the money, we do not buy items. We watch our expenditures very closely."

Another superintendent replied, "Our board has finally realized they cannot spend money they do not have. We look at all expenditures very carefully to see if they can be deferred or canceled."

A treasurer responded, "The board has enacted a policy that prohibits the employment of staff beyond the number provided in the formula. We have used positions allowed in Step 7 of the formula and contracted for services from RESA rather that employing additional personnel."

Other respondents reported:

"Our board attempts to pay for as many necessities as possible from excess levy funds."

"We are very cautious about personnel additions. Some of our decisions have hurt programs and program delivery."

"Our county uses a lease purchase arrangement wherever possible, defers maintenance, and very closely monitors all purchases to ensure they are necessary to the operation of the schools."

"We are continuing to implement staffing levels as close to the formula as possible. We are also looking at consolidation of schools and services where possible. Also, continual monitoring of revenues and expenditures as well as living within the guidelines of the budget."

"We perform annual reductions in force and constant review of hiring practices and attempt to maintain staffing levels to meet the formula. Capital expenditures are made only when necessary unless sufficient funds are available in the current year budget." 
"We have restricted all travel and travel costs for sports and performing groups. Travel expenses are shared with booster groups."

One treasurer offered this comment, "The best solution is to monitor the budget, give accurate updates to the school board and superintendent, and the bottom line is - do not spend it, if you do not have it."

Research Question 5. If closure and consolidation were used to avoid deficit spending, what was the impact on the budget? Twenty-one of the superintendents and nineteen of the treasurers who reported using closure and consolidation to avoid a budget deficit did not experience a budget deficit. Eight of the superintendents and nine of the treasurers reported a budget deficit occurred in their counties when school closure and consolidation was attempted. Four of the superintendents and three of the treasurers responded that school closure and consolidation had no impact on the budget.

The following statements are examples of expenditure savings or increases as a result of school closure or consolidation reported by the county superintendents and treasurers.

"Consolidation assisted in keeping the number of employees closer to the state aid formula. Utility costs and insurance expense were reduced as was the expenditure of funds for maintenance for older buildings."

"School consolidation allowed for a reduction in staff and the operational costs of the building was reduced."

"Personnel, utility, split grade allocation, and maintenance costs were reduced."

"The consolidation of schools reduced the expenditures for staff, maintenance, and utilities." 


\section{Research Question 6. What is the effect of continuing budget deficits on the academic}

and extracurricular programs? Based on an analysis of the data in Table 9 the most debilitating effect of continuing budget deficits is in the area of academic offerings. Thirteen superintendents and twelve treasurers of county boards of education experiencing continuing budget deficits reported the reduction of instructional supplies as a result of deficit spending.

Thirteen superintendents and eleven treasurers of counties experiencing continuing budget deficits reported decreasing course offerings as a result of deficit spending. Reduction of expenditures for equipment was reported by six of the superintendents and eight of the treasurers.

Counties have reduced funds for extracurricular activities, expenditures for curricular and extracurricular salaries, and transportation for curricular and extracurricular activities, in reaction to continuing budget deficits.

Treasurers of county boards of education experiencing continuing budget deficits provided examples of the effects of deficits on the ability of schools to operate.

"Extracurricular programs suffer greatly. The reduction of supplemental salaries to coaches and sponsors discourages talented people from continuing their involvement with sports and club sponsorships.”

"For counties that have continuing budget deficits extracurricular programs have to be sacrificed or curtailed until the deficit is rectified. When we were in deficit, academics received very little funding until extracurricular and supplemental programs were reduced.”

"Deficits cause the loss of services and curricular offerings."

"Deficit spending required us to reduce course offerings and increase class size." 
Comments from county superintendents experiencing continuing budget deficits are similar to those received from the treasurers.

"Children are not provided programs and materials that will allow them to grow academically. Staff morale is not what it should be because they do not have the materials they need to work with to improve instruction."

"How do you measure the effect of cutting academic and extracurricular programs? It is easy to calculate their cost, but, how do you put a dollar amount on the benefits our students derive from these programs?"

"Some teachers at the high school and middle school have class sets only which precludes students from having a book to take home."

"We reduced expenditures for instructional materials and supplies and discontinued summer school. Also, we provided less maintenance, construction, and reduced expenditures for extracurricular activities."

"Extracurricular activities are reduced or eliminated. Academics lose in terms of staff, course offerings, and materials."

"We deferred the purchase of textbooks and other curricular materials on three different occasions."

"If counties continue to run deficits, it strangles any efforts to improve the system academically. Over time it leads to a system not being able to meet new and increasing standards. Continued deficits usually mean that the system is not changing to meet the new demands and lacks the ability to self-correct its deficiencies. Eventually, student performance 
will be affected negatively, management will be more vulnerable to instability, morale will lower, and public relations will be diminished."

\section{Anecdotal Comments}

As a part of the survey the researcher asked respondents to provide any comments relative to this survey and the contributing factors to budget deficits between June 30, 1988 and June 30, 1997.

Poor Financial Decisions. The major reason reported for budget deficits prior to 1988 was poor financial decisions made by the county superintendent and board of education often related to expenditures in excess of revenue provided for construction projects. Since 1988 and the passage of Senate Bill 14, the reasons given by all of the respondents for budget deficits were inability to manage the reductions mandated by the school aid formula.

Personnel Reduction. Some of the superintendents and treasurers of counties experiencing budget deficits reported reducing the number of service personnel employed. Though the reduction in personnel was effective in reducing expenditures, the staffing requirements for pupil transportation consumed the majority of the service personnel positions allowed and funded within the formula. The remaining positions were inadequate to provide for the remaining service personnel needs of the county boards of education and individual schools.

Excessive Employment and Contract Time. Many of the respondents indicated the practice of employing an excessive number of professional and service personnel for contracts exceeding two hundred days is a primary contributor to deficit spending. The school aid formula provides for two hundred days of employment for professional personnel. All days in excess of the number allowed in the formula must be paid from funds not related to the formula. Although 
service personnel are funded for the number of days employed under the Public School Support Program, the number counts against the maximum limits. For example, each 261-day employee counts as 1.305 full-time equivalent; therefore, a county which hires service personnel for a contracted period in excess of two hundred days must employ fewer personnel to remain within the funding limits.

Unauthorized Obligation of Funds. Some superintendents and treasurers also expressed concern regarding the obligation of funds without the approval of the superintendent, assistant superintendent, or chief school business official which results in expenditures in excess of available revenues. Without constant monitoring of the expenditure budget the possibility of a budget deficit is imminent.

Excessive Operations. Other comments received indicated that the operation of a large number of facilities, providing more services than required or providing them in an inefficient manner and the absence of an excess levy are contributing factors to a budget deficit.

One superintendent explicitly stated. " The reduction of professional staff in SB 14 from fifty-five per thousand to fifty-three per thousand was truly the single biggest financial blow to West Virginia schools and the leading contributor to budget deficits." 


\section{CHAPTER 5}

\section{CONCLUSIONS AND RECOMMENDATIONS OVERVIEW OF THE STUDY}

The objective of this study was to review and analyze the common factors leading to county boards of education to increasingly experience budget deficits between school years 19871988 and 1996-1997. Article XII, Section One of the Constitution for the State of West Virginia requires the legislature to provide for a thorough and efficient system of free schools. The cornerstone legislation passed during the reform movement of 1988 was Senate Bill 14. This bill initiated the first reduction in the number of professional and service personnel funded in the school aid formula. Prior to the enactment of this legislation the school aid formula encouraged county boards of education to employ personnel to provide services to students identified in the various categories of special education. This funding scheme caused the adjusted enrollment to increase while the net enrollment of pupils throughout the state was decreasing. The increasing adjusted enrollment demanded more funds for personnel within the formula with fewer students to educate. Additionally, the state at this time was also experiencing increased financial difficulties.

The effect of reform legislation enacted by the West Virginia Legislature on the financial operations of county boards of education was reviewed and analyzed to determine if 
increasing numbers of county boards of education experienced deficit spending as a result of the enactment of this legislation.

Beginning in 1988, the legislature revised the school aid formula to cause:

- the number of personnel to decrease at a more rapid pace than the decline of net enrollment by enacting a net enrollment ratio that decreased over a period of seven years;

- the adjusted enrollment ratios to decrease over a two-year period;

- the ratio of professional instructional personnel to adjusted enrollment to increase requiring more professional instructional personnel; and

- caps on the number of gifted students permitted for calculating the formula which resulted in a decrease in the adjusted enrollment count. (Arrington, 1994).

To determine the effect of these legislated changes on the financial operation of county boards of education, data collected and provided by the West Virginia Department of Education were analyzed. Data were also collected from surveys of all fifty-five county superintendents and treasurers. The study utilized a combined descriptive and anecdotal data research design which included the use of surveys and document analysis.

The findings of the study were categorized in Chapter 4 into eight areas:

- Primary Information

- Research Question 1 - To what extent did the reduction of personnel funded in the formula affect the increased incidence of budget deficits?

- Research Question 2 - What steps did county boards of education take to avoid deficit spending? 
- Research Question 3 - Did county boards of education experience a budget deficit prior to $1988 ?$

- Research Question 4 - What policies and practices are counties continually implementing to avoid a budget deficit?

- Research Question 5 - If closure and consolidation of schools were used to avoid deficit spending, what was the impact on the budget?

- Research Question 6 - What was the effect of continuing budget deficits on the academic and extracurricular programs?

- Anecdotal Comments - Provide any comments relevant to this survey and the contributing factors to budget deficits between June 30, 1988, and June 30, 1997.

\section{CONCLUSIONS}

Based on the data analysis and findings, the researcher concludes:

1. The preeminent factor contributing to county boards of education experiencing financial deficit was the reduction of the number of employees allowed and funded in the school aid formula. Those school districts that failed to reduce the number of personnel employed at the rate mandated by the reductions within the formula experienced a budget deficit as reported on their annual financial report. The school districts either could not reduce the number of personnel rapidly enough to comply with the declining personnel limits of the formula or felt it imperative to employ personnel in excess of that provided in the formula to deliver services to the students. 
2. The absence of an excess levy was a primary factor leading to county boards of education ending the fiscal year with a financial deficit. In the school years between 1987-1988 and 1996-1997, a total of thirty-six different school systems incurred deficit spending as reported on their annual financial statements. The majority of the reported deficits may be attributed to reductions in state aid for the years 1988$1989,1989-1990,1991-1992$, and 1992-1993 coupled with the under-funding of the state aid formula by the legislature in school years 1989-1990 and 1990-1991. The counties that did not have an excess levy in place experienced continuing deficit spending during the school years 1987-1988 and 1996-1997.

3. The reduction in state aid during the fiscal years 1988-1989, 1989-1990, 1991-1992, and $1992-1993$, for a total of $\$ 13,020,350$ in addition to the $\$ 10,686,340$ underfunding of the formula by the legislature in 1989-1990 and 1990-1991, caused many of the county boards of education to report deficit budgets. In addition to the amount of the state aid reductions, the timing of the reductions was detrimental to many school districts. The state aid reductions were announced during the middle of each fiscal year in which they occurred and boards of education reported they were unable to reduce personnel because of contractual obligations; therefore, counties had no areas of the budget to reduce during the last half of the school year.

4. The expansion of the types of personnel included in the definitions of teacher and professional instructional personnel was changed to include school nurses, school psychologists and attendance directors (WV Code §18-9A-2). As a result of this legislation there were fewer administrative positions and classroom teachers 
allowed and funded within the formula. County boards of education who failed to recognize the funding changes and reduce the appropriate personnel found themselves with employees in excess of those provided in the formula and greatly increased the possibility of a budget deficit.

5. The increased reduction of the number of service personnel resulting from the implementation of the employment caps beginning in 1989-1990 through 19941995 based upon net enrollment required county boards of education to reduce service personnel more rapidly than that previously dictated by the decline in student enrollment. County boards of education and superintendents who refuse to reduce service personnel to the number allowed and funded will incur a budget deficit.

6. During the school years between 1987-1988 and 1996-1997 student enrollment in the school districts in West Virginia continued to decline with few exceptions. Those county boards of education with declining enrollment must have a plan to provide adequate facilities for the student population. Many of the districts had more school buildings than necessary to economically deliver the curriculum to a declining student population. These facilities were often older buildings without adequate heating, air conditioning or electrical capacity to enable the economical delivery of a modern technological curriculum. Failure to close or consolidate facilities to reduce expenditures is a factor which will contribute to the possibility of a financial deficit. 
7. The five common factors leading to deficit spending:

a. Poor Financial Decisions

- Expenditures that are in excess of available revenues not being addressed adequately

- No excess levy in effect

b. Personnel Reduction

- Decrease in enrollment from previous year without a corresponding reduction in the number of professional and service personnel employed

c. Excessive Employment and Contract Time

- The number of professional educators employed in excess of the number funded through the Public School Support Program

- The number of service personnel employed in excess of the number funded through the Public School Support Program

- The excess number of extended employment contracts (contracts beyond 200 days) for professional educators

- Excess number of extended employment contracts (contracts beyond 200 days) for service personnel. Although service personnel are funded for the number of days employed under the Public School Support Program, the number county against the maximum limits. For example, each 261-day employee counts as 1.305 employees. 
d. Unauthorized Obligation of Funds

- Obligation of funds without approval of the superintendent or chief school business official

e. Excessive Operations

- Providing more services than required, or providing them in a less efficient manner

- Operation of an excessive number of school facilities

\section{IMPLICATIONS}

As data were reviewed and analyzed for this research project, other implications became apparent to the researcher. Those implications are provided for the interest of the reader.

\section{Implication 1}

The analysis of continuing budget deficits between the school years 1988-1989 and 19961997 revealed that rural counties with low student population and no excess levy experienced a more severe history of recurring deficits. County boards of education within this group must analyze their budget revenues and expenditures to determine the areas of the budget which are causing deficit spending. The school aid formula needs to be examined to determine if the method of funding small rural counties provides the capacity needed to deliver the educational programs. The majority of these county boards of education do not have an excess levy in place. The method of providing revenue of this type needs to be developed on a county- or state-wide basis. 


\section{Implication 2}

Many of the respondents to the survey reported the reduction of administrator, service, and instructional positions. In addition to the reduction of positions, the employment calendar was reduced for these same positions to reduce expenditures and defray deficit spending. The work performed by the deleted personnel was distributed to other staff members. With the reduction of personnel and employment terms, staff development was curtailed or eliminated. There were fewer course offerings at the secondary level, extracurricular activities were deleted or reduced, and academic field trips were reduced or eliminated. Instructional materials and supplies were also reduced in the schools. In addition, the use of substitute personnel was greatly reduced and monitored to avoid a budget deficit. With these reductions the counties were not in a position to provide exemplary instructional programs.

\section{Implication 3}

As a result of the threat of looming budget deficits, the budget was constantly monitored and some expenditures were deferred. Some county boards of education required approval of all purchases by the superintendent or treasurer and required timely reporting on the status of the annual adopted budget. Many school systems improved their purchasing procedures by competitively bidding services, leasing services, and collaborating with the RESAs for purchases and services. The experience of budget deficits has forced many counties to closely monitor the annual operating budget.

\section{Implication 4}

Maintenance in many of the districts reporting a budget deficit was often deferred or eliminated during the period of deficit spending. Some respondents remarked that maintenance 
deferred is maintenance not performed. It creates a crisis in the future which will often result in a much larger capital outlay.

\section{RECOMMENDATIONS}

As a result of reviewing and analyzing the data and responses to the survey, and as a result of reaching the conclusions listed in this chapter, recommendations are offered for consideration by the West Virginia Legislature, West Virginia Department of Education, and West Virginia county boards of education, as well as for future research.

\section{West Virginia Legislature}

The following recommendations are suggested for consideration by the West Virginia Senate and the House of Delegates:

1. The net enrollment cap on professional and service personnel is severely limiting county boards of education in employing adequate numbers of personnel within their districts. All fifty-five county boards of education are limited in the number of service personnel allowed and funded in the formula. It will only be a short time until all fifty-five county boards of education are limited by the net cap for professional personnel. The net caps as provided in the formula should be changed to one cap which would provide enough personnel to provide for the needs of the students and boards of education. The caps should also be compatible for professional and service personnel.

2. The formula has various growth limits in the amount of funding allowed in the steps of the formula. Consideration should be given to removing the limits of growth 
within the formula to adequately provide the funds necessary to fully fund the formula.

\section{West Virginia Department of Education}

The following recommendations are suggested for research and consideration by the West Virginia Department of Education:

1. The formula, as it currently exists, is judged to be one of the most equitable school funding formulas among the states. Research the school aid formula to determine if the funds provided in the formula are adequate to meet the expectations of the curriculum demands on the county boards of education.

2. Recommend changes in the school aid formula that need to be made to insure that all county boards of education have adequate resources to adopt an annual budget without experiencing deficit spending.

\section{County Boards of Education}

The following recommendations are suggested for research and consideration by the county boards of education:

1. Determine the facilities needs for the future and plan to modify the facility configuration to reflect the current and future population projections.

2. Determine the staffing needs for professional and service personnel necessary to deliver a thorough and efficient education to the students of the county and communicate the needs to the West Virginia Department of Education and West Virginia Legislature. 


\section{Future Research}

1. Review and analyze the school aid formula to determine if the funds provided are adequate to deliver a thorough and efficient education in West Virginia public schools.

2. Review and analyze the school aid formula to determine if the number of professional and service personnel allowed and funded in the formula is adequate to meet the needs of the public schools in West Virginia.

3. Review and analyze the facility configuration within the county boards of education to determine if the buildings are designed and equipped to deliver the required curriculum. 


\section{BIBLIOGRAPHY}

Alexander, Kern, and K. Forbis Jordan. Constitutional Reform of School Finance. Washington, D.C.: U.S. Department of Education, 1965.

Arrington, Carolyn R. Education Reform: How Has Downsizing Affected The West Virginia School System? Doctoral dissertation, West Virginia University, 1994.

Bolman, Lee G., and Terrence E. Deal. Reframing Organizations Artistry, Choice, and Leadership. San Francisco: Jossey-Bass Publishers, 1991.

Boyer, Ernest L. The Basic School - A Community For Learning. Princeton, New Jersey: The Carnegie Foundation For The Advancement Of Teaching, 1995.

Cunningham, W. G. and D. W. Gresso. Cultural Leadership. Boston: Allyn \& Bacon, 1993.

Cyert, R. M., and J. G. March. A Behavioral Theory of the Firm. Englewood Cliffs, New Jersey: Prentice-Hall, 1963.

Deal, Terrence E. “The Symbolism of Effective Schools.” Elementary School Journal 85 (1985): 601-620.

Deal, Terrence E., and A. A. Kennedy. Corporate Cultures: The Rites and Rituals of Corporate Life. Reading, Massachusetts: Addison-Wesley, 1982. 
Deal, Terrence E., and M. Wise. "Planning, Plotting, and Playing in Education's Era of Decline.” In V. Baldridge and T. Deal (Eds.), The Dynamics of Educational Change. San Francisco: McCutchan, 1983.

Etzioni, A. A Comparative Analysis of Complex Organizations. New York: Free Press, 1975.

Finney, Robert, G. Powerful Budgeting For Better Planning and Management. New York: American Management Association, 1993.

Firestone, W. A., and B. L. Wilson. "Using Bureaucratic and Cultural Linkages to Improve Instruction: The Principal's Contribution. Educational Administration Quarterly 21, (1986): 7-31.

Fraenkel, J. R., and N. E. Wallen. How To Design And Evaluate Research In Education. New York: McGraw-Hill Publishing Co., 1990.

French, J. R. P., and B. H. Raven. “The Bases of Social Power.” In D. Cartwright (ed.), Studies in Social Power. Ann Arbor, Michigan: Institute for Social Research, 1968.

Fromm, E. Man for Himself. New York: Farrar \& Rinehart, 1948.

Gilmer, B. H. Industrial Psychology (2 ${ }^{\text {nd }}$ ed.). New York: McGraw-Hill, 1966.

Greene, C. N., and P. M. Podsakoff. "Effects of Withdrawal of a Performance Contingent Reward of Supervisory Influence and Power." Academy of Management Journal 24 (1981): 527-542.

House Bill 2326. Regular Session of the West Virginia Legislature, 1989.

House Bill 101. Special Session of the West Virginia Legislature, 1990.

Hoy, Wayne K., and Cecil G. Miskel. Educational Administration Theory, Research and Practice. New York: McGraw-Hill, Inc., 1996. 
Huber, V. L. "The Sources, Uses, and Conservation of Managerial Power." Personnel 51 (1981): 66-67.

Jaeger, R. M. "Survey Research Methods In Education.” Complimentary Methods For Research In Education, pp. 303-338. Washington, D.C.: American Educational Research Association, 1988.

Kotter, J. P. “Power, Success, and Organizational Effectiveness.” Organizational Dynamics, 6, (1978): 27-40.

Miles, M. B. "Planned Change and Organizational Health: Figure and Ground.” In F. D. Carver and T. J. Sergiovanni (Eds.), Organizations and Human Behavior, pp. 375-391. New York: McGraw-Hill, 1969.

Mintzberg, H. Power In and Around Organizations. Englewood Cliffs, New Jersey: PrenticeHall, 1983.

Olsen, M. E. The Logic of Collective Action: Public Goods and the Theory of Groups. Cambridge, Massachusetts: Harvard University Press, 1965.

Olsen, M. E. “A Theory of Groups and Organizations.” In B. M. Russett (Ed.), Economic Theory of International Politics. Chicago: Markham, 1968.

Poole, M. S. “Communication and Organizational Climates: Review, Critique, and a New Perspective.” In R. D. McPhee and P. K. Tompkins (Eds.), Organizational Communications: Traditional Themes and New Directions, pp. 79-108. Beverly Hills, California: Sage, 1985.

Ridler, George E., and Robert J. Schocley. School Administrator's Budget Handbook. Englewood Cliffs, New Jersey: Prentice Hall, 1989. 
Schein, E. H. Organizational Culture and Leadership (2 ${ }^{\text {nd }}$ ed.). San Francisco: Jossey-Bass, 1992.

School Laws of West Virginia. Charlottesville, VA: The Michie Company, 1989.

School Laws of West Virginia. Charlottesville, VA: The Michie Company, 1991.

School Laws of West Virginia. Charlottesville, VA: The Michie Company, 1993.

School Laws of West Virginia. Charlottesville, VA: Lexis Law Publishing, 1997.

School Laws of West Virginia. Charlottesville, VA: Lexis Law Publishing, 1999.

Senate Bill 14. Regular Session of the West Virginia Legislature, 1988.

Senate Bill 8. Third Extraordinary Session of the West Virginia Legislature, 1990.

Sergiovanni, T. J. Moral Leadership: Getting to the Heart of School Improvement. San Francisco: Jossey-Bass, 1992.

Sherman, Eliot H. Operational Planning and Budgeting. Denton, Texas: Professional Development Institute, 1994.

Shim, Jae K., and Joel G. Siegal. Complete Budgeting Deskbook. Paramus, New Jersey: Prentice Hall, 1994.

Simon, H. Administrative Behavior (2 $2^{\text {nd }}$ ed.). New York: Macmillan, 1957.

Simon, H. Hidden Champions: Lessons from 500 of the World's Best Unknown Companies. Boston: Harvard Business School Press, 1996.

Steinhoff, C. R., and R. G. Owens. "The Organizational Culture and Assessment Inventory: A Metaphorical Analysis in Educational Settings." Journal of Educational Administration 27, no. 3, (1989): 17-23. 
Tuckman, B. W. Conducting Educational Research. New York: Harcourt Brace Jovanovich, Inc., 1978.

Van Dalen, D. B., and W. J. Meyer. Understanding Educational Research: An Introduction. New York: McGraw-Hill Book Co., 1962.

Weber, M. The Theory of Social and Economic Organization. (T. Parsons, trans). New York: Free Press, 1947.

Yukl, G. A. Leadership in Organizations. Englewood Cliffs, New Jersey: Prentice-Hall, 1981. 


\section{APPENDIX A}

COUNTY BOARDS OF EDUCATION DATA 
Table A-1

Comparison of Number of Students (Net Enrollment) Per District

Between School Years 1987-1988 and 1996-1997

\begin{tabular}{|c|c|c|c|c|}
\hline \multirow[b]{2}{*}{ County } & \multicolumn{2}{|c|}{ School Year } & \multirow{2}{*}{$\begin{array}{l}\text { Increase } \\
\text { (Decrease) }\end{array}$} & \multirow{2}{*}{$\begin{array}{l}\text { Percent } \\
\text { Change }\end{array}$} \\
\hline & 1987-1988 & 1996-1997 & & \\
\hline Barbour & 3,080 & $2,855.71$ & (224.29) & -7.28 \\
\hline Berkeley & 9,543 & $11,511.47$ & $1,968.47$ & 20.63 \\
\hline Boone & 6,108 & 4,766.17 & $(1,341.83)$ & -21.97 \\
\hline Braxton & 2,872 & $2,762.00$ & (110.00) & -3.83 \\
\hline Brooke & 4,695 & $3,934.86$ & (760.14) & -16.19 \\
\hline Cabell & 15,374 & $13,793.11$ & $(1,580.89)$ & -10.28 \\
\hline Calhoun & 1,712 & $1,576.54$ & (135.46) & -7.91 \\
\hline Clay & 2,417 & $2,156.00$ & (261.00) & -10.80 \\
\hline Doddridge & 1,367 & $1,363.74$ & (3.26) & -0.24 \\
\hline Fayette & 10,227 & $8,362.57$ & $(1,864.43)$ & -18.23 \\
\hline Gilmer & 1,355 & $1,293.36$ & (61.64) & -4.55 \\
\hline Grant & 2,047 & $1,929.86$ & (117.14) & -5.72 \\
\hline Greenbrier & 6,335 & $5,922.30$ & (412.70) & -6.51 \\
\hline Hampshire & 2,836 & $3,509.13$ & 673.13 & 23.74 \\
\hline Hancock & 5,985 & $4,868.07$ & $(1,116.93)$ & -18.66 \\
\hline Hardy & 1,821 & $1,996.92$ & 175.92 & 9.66 \\
\hline Harrison & 12,605 & $12,216.16$ & (388.84) & -3.08 \\
\hline Jackson & 5,197 & $5,133.36$ & (63.64) & -1.22 \\
\hline Jefferson & 6,043 & $6,497.57$ & 454.57 & 7.52 \\
\hline Kanawha & 35,102 & $31,690.81$ & $(3,411.19)$ & -9.72 \\
\hline Lewis & 3,230 & $2,846.55$ & (383.45) & -11.87 \\
\hline Lincoln & 4,998 & $4,284.21$ & (713.79) & -14.28 \\
\hline Logan & 10,452 & $7,214.47$ & $(3,237.53)$ & -30.98 \\
\hline Marion & 9,672 & $9,114.67$ & (557.33) & -5.76 \\
\hline Marshall & 6,610 & $5,955.00$ & $(655.00)$ & -9.91 \\
\hline Mason & 4,872 & $4,540.52$ & (331.48) & -6.80 \\
\hline Mercer & 12,345 & $10,125.97$ & $(2,219.03)$ & -17.98 \\
\hline Mineral & 4,809 & $4,888.68$ & 79.68 & 1.66 \\
\hline Mingo & 8,795 & $6,263.40$ & $(2,531.60)$ & -28.78 \\
\hline Monongalia & 9,844 & $10,295.53$ & 451.53 & 4.59 \\
\hline Monroe & 2,127 & $1,937.50$ & $(189.50)$ & -8.91 \\
\hline Morgan & 2,075 & $2,244.25$ & 169.25 & 8.16 \\
\hline McDowell & 9,243 & $6,070.18$ & $(3,172.82)$ & -34.33 \\
\hline Nicholas & 5,372 & $5,018.05$ & (353.95) & -6.59 \\
\hline Ohio & 6,495 & 6.380 .50 & (114.50) & -1.76 \\
\hline Pendleton & 1,392 & $1,453.20$ & 61.20 & 4.40 \\
\hline Pleasants & 1,478 & $1,460.94$ & (17.06) & -1.15 \\
\hline Pocahontas & 1,565 & $1,516.40$ & (48.60) & -3.11 \\
\hline Preston & 5,916 & $5,293.00$ & $(623.00)$ & -10.53 \\
\hline Putnam & 7,825 & $8,740.35$ & 915.35 & 11.70 \\
\hline Raleigh & 15,649 & $13,189.05$ & $(2,459.95)$ & -15.72 \\
\hline Randolph & 4,894 & $5,013.06$ & 119.06 & 2.43 \\
\hline Ritchie & 1,899 & $1,838.42$ & $(60.58)$ & -3.19 \\
\hline Roane & 3,143 & $2,999.73$ & (143.27) & -4.56 \\
\hline Summers & 2,345 & $1,853.00$ & $(492.00)$ & -20.98 \\
\hline Taylor & 2,920 & $2,785.37$ & (134.63) & -4.61 \\
\hline Tucker & 1,443 & $1,344.10$ & (98.90) & -6.85 \\
\hline Tyler & 2,017 & $1,708.27$ & (308.73) & -15.31 \\
\hline Upshur & 4,481 & $4,274.50$ & $(206.50)$ & -4.61 \\
\hline Wayne & 8,849 & $7,872.80$ & $(976.20)$ & -11.03 \\
\hline Webster & 2,468 & $1,850.80$ & $(617.20)$ & -25.01 \\
\hline Wetzel & 3,958 & $3,737.14$ & (220.86) & -5.58 \\
\hline Wirt & 1,041 & $1,198.20$ & 157.20 & 15.10 \\
\hline Wood & 15,416 & $14,714.00$ & $(702.00)$ & -4.55 \\
\hline Wyoming & 7,603 & $5,244.33$ & $(2,358.67)$ & -31.02 \\
\hline State & 333,962 & $303,405.85$ & $(30,556.15)$ & -9.15 \\
\hline
\end{tabular}

Note: Certified adults included in net enrollment beginning with 1988-1989 school year. 
Table A-2

Comparison of Number of Students (Adjusted Enrollment) Per District Between School Years 1987-1988 and 1996-1997

\begin{tabular}{|c|c|c|c|c|}
\hline \multirow[b]{2}{*}{ County } & \multicolumn{2}{|c|}{ School Year } & \multirow{2}{*}{$\begin{array}{l}\text { Increase } \\
\text { (Decrease) }\end{array}$} & \multirow{2}{*}{$\begin{array}{l}\text { Percent } \\
\text { Change }\end{array}$} \\
\hline & $1987-1988$ & 1996-1997 & & \\
\hline Barbour & 4,030 & $3,919.71$ & (110.29) & -2.74 \\
\hline Berkeley & 12,479 & $15,103.47$ & $2,624.47$ & 21.03 \\
\hline Boone & 7,470 & $6,656.17$ & $(813.83)$ & -10.89 \\
\hline Braxton & 4,274 & $3,972.00$ & (302.00) & -7.07 \\
\hline Brooke & 6,565 & $5,369.86$ & $(1,195.14)$ & -18.20 \\
\hline Cabell & 20,836 & $18,855.11$ & $(1,980.89)$ & -9.51 \\
\hline Calhoun & 2,570 & $2,206.54$ & $(363.46)$ & -14.14 \\
\hline Clay & 3,059 & $2,944.00$ & (115.00) & -3.76 \\
\hline Doddridge & 1,905 & $1,923.74$ & 18.74 & 0.98 \\
\hline Fayette & 12,793 & $11,256.57$ & $(1,536.43)$ & -12.01 \\
\hline Gilmer & 1.873 & $1,787.36$ & (85.64) & -4.57 \\
\hline Grant & 2,713 & $2,592.86$ & (120.14) & -4.43 \\
\hline Greenbrier & 8,273 & $8,074.30$ & $(198.70)$ & -2.40 \\
\hline Hampshire & 3,768 & $4,790.13$ & $1,022.13$ & 27.13 \\
\hline Hancock & 7,275 & $6,300.07$ & (974.93) & -13.40 \\
\hline Hardy & 2,549 & 2.710 .92 & 161.92 & 6.35 \\
\hline Harrison & 16,799 & $16,564.16$ & (234.84) & -1.40 \\
\hline Jackson & 7,177 & $7,111.36$ & (65.64) & -0.91 \\
\hline Jefferson & 7,739 & $8,887.57$ & $1,148.57$ & 14.84 \\
\hline Kanawha & 46,602 & $42,419.81$ & $(4,182.19)$ & -8.97 \\
\hline Lewis & 4,352 & $4,140.55$ & (211.45) & -4.86 \\
\hline Lincoln & 6,558 & $6,109.21$ & (448.79) & -6.84 \\
\hline Logan & 12,498 & $9,679.47$ & $(2,818.53)$ & -22.55 \\
\hline Marion & 13,194 & $12,024.67$ & $(1,169.33)$ & -8.86 \\
\hline Marshall & 9,044 & $8,257.00$ & (787.00) & -8.70 \\
\hline Mason & 6,348 & $6,535.52$ & 187.52 & 2.95 \\
\hline Mercer & 16,545 & $13,655.97$ & $(2,889.03)$ & -17.46 \\
\hline Mineral & 7,101 & $6,806.68$ & $(294.32)$ & -4.14 \\
\hline Mingo & 10,449 & $8,530.40$ & $(1,918.60)$ & -18.36 \\
\hline Monongalia & 13,010 & $13,411.53$ & 401.53 & 3.09 \\
\hline Monroe & 3,027 & 2.595 .50 & $(431.50)$ & -14.26 \\
\hline Morgan & 2,879 & $2,941.25$ & 62.25 & 2.16 \\
\hline McDowell & 11,885 & $8,711.18$ & $(3,173.82)$ & -26.70 \\
\hline Nicholas & 7,418 & $7,000.05$ & (417.95) & -5.63 \\
\hline Ohio & 9,157 & $8,344.50$ & $(812.50)$ & -8.87 \\
\hline Pendleton & 2,158 & $2,003.20$ & $(154.80)$ & -7.17 \\
\hline Pleasants & 1,900 & $2,057.94$ & 157.94 & 8.31 \\
\hline Pocahontas & 2,215 & $2,117.40$ & $(97.60)$ & -4.41 \\
\hline Preston & 8,056 & $7,298.00$ & $(758.00)$ & -9.41 \\
\hline Putnam & 9,929 & $11,898.35$ & $1,969.35$ & 19.83 \\
\hline Raleigh & 18,931 & $17,879.05$ & $(1,051.95)$ & -5.56 \\
\hline Randolph & 6,980 & $6,893.06$ & (86.94) & -1.25 \\
\hline Ritchie & 2,489 & $2,611.42$ & 122.42 & 4.92 \\
\hline Roane & 4,541 & $4,185.73$ & $(355.27)$ & -7.82 \\
\hline Summers & 3,189 & $2,565.00$ & $(624.00)$ & -19.57 \\
\hline Taylor & 4,010 & $3,906.37$ & (103.63) & -2.58 \\
\hline Tucker & 2,045 & $1,826.10$ & (218.90) & -10.70 \\
\hline Tyler & 2,801 & $2,425.27$ & (375.73) & -13.41 \\
\hline Upshur & 5,893 & $5,703.50$ & (189.50) & -3.22 \\
\hline Wayne & 11,039 & $10,683.80$ & $(355.20)$ & -3.22 \\
\hline Webster & 3,384 & $2,590.80$ & $(793.20)$ & -23.44 \\
\hline Wetzel & 5,384 & $5,168.14$ & (215.86) & -4.01 \\
\hline Wirt & 1,443 & $1,666.20$ & 223.20 & 15.47 \\
\hline Wood & 22,050 & $19,516.00$ & $(2,534.00)$ & -11.49 \\
\hline Wyoming & 9,525 & $7,072.33$ & $(2,452.67)$ & -25.75 \\
\hline State & 442,176 & $412,256.85$ & $(29,919.15)$ & -6.77 \\
\hline
\end{tabular}

Note: Certified adults included in net enrollment beginning with 1988-1989 school year. 
Table A-3

Comparison of Total Number of Personnel Employed (All Funding Sources)

Per District Between School Years 1987-1988 and 1996-1997

\begin{tabular}{|c|c|c|c|c|}
\hline \multirow[b]{2}{*}{ County } & \multicolumn{2}{|c|}{ School Year } & \multirow{2}{*}{$\begin{array}{l}\text { Increase } \\
\text { (Decrease) }\end{array}$} & \multirow{2}{*}{$\begin{array}{l}\text { Percent } \\
\text { Change }\end{array}$} \\
\hline & $1987-1988$ & 1996-1997 & & \\
\hline Barbour & 375.03 & 348.60 & (26.43) & -7.05 \\
\hline Berkeley & $1,181.73$ & $1,454.90$ & 273.17 & 23.12 \\
\hline Boone & 744.00 & 649.50 & $(94.50)$ & -12.70 \\
\hline Braxton & 404.10 & 350.36 & $(53.74)$ & -13.30 \\
\hline Brooke & 595.55 & 498.50 & (97.05) & -16.30 \\
\hline Cabell & 1.880 .96 & 1.790 .30 & (90.66) & -4.82 \\
\hline Calhoun & 241.66 & 211.50 & (30.16) & -12.48 \\
\hline Clay & 296.00 & 280.38 & (15.62) & -5.28 \\
\hline Doddridge & 199.00 & 181.50 & $(17.50)$ & -8.79 \\
\hline Fayette & $1,189.36$ & $1,044.00$ & $(145.36)$ & -12.22 \\
\hline Gilmer & 188.88 & 158.00 & $(30.88)$ & -16.35 \\
\hline Grant & 268.39 & 238.00 & (30.39) & -11.32 \\
\hline Greenbrier & 757.81 & 715.14 & $(42.67)$ & -5.63 \\
\hline Hampshire & 358.02 & 403.50 & 45.48 & 12.70 \\
\hline Hancock & 652.50 & 595.50 & $(57.00)$ & -8.74 \\
\hline Hardy & 240.50 & 230.85 & $(9.65)$ & -4.01 \\
\hline Harrison & $1,541.13$ & $1,475.80$ & (65.33) & -4.24 \\
\hline Jackson & 648.10 & 642.42 & $(5.68)$ & -0.88 \\
\hline Jefferson & 677.00 & 764.50 & 87.50 & 12.92 \\
\hline Kanawha & 4.354 .50 & $3,887.68$ & $(466.82)$ & -10.72 \\
\hline Lewis & 406.00 & 375.00 & $(31.00)$ & -7.64 \\
\hline Lincoln & 650.22 & 579.00 & $(71.22)$ & -10.95 \\
\hline Logan & $1,245.50$ & 946.50 & $(299.00)$ & -24.01 \\
\hline Marion & $1,198.43$ & $1,134.51$ & (63.92) & -5.33 \\
\hline Marshall & 814.00 & 731.00 & $(83.00)$ & -10.20 \\
\hline Mason & 606.50 & 603.00 & $(3.50)$ & -0.58 \\
\hline Mercer & $1,596.00$ & $1,293.80$ & $(302.20)$ & -18.93 \\
\hline Mineral & 647.00 & 597.17 & (49.83) & -7.70 \\
\hline Mingo & 992.00 & 850.00 & (142.00) & -14.31 \\
\hline Monongalia & $1,175.77$ & $1,264.88$ & 89.11 & 7.58 \\
\hline Monroe & 290.45 & 254.80 & $(35.65)$ & -12.27 \\
\hline Morgan & 256.27 & 261.40 & 5.13 & 2.00 \\
\hline McDowell & $1,205.00$ & 858.50 & $(346.50)$ & -28.76 \\
\hline Nicholas & 690.56 & 655.00 & $(35.56)$ & -5.15 \\
\hline Ohio & 830.45 & 780.50 & (49.95) & -6.01 \\
\hline Pendleton & 200.50 & 180.50 & $(20.00)$ & -9.98 \\
\hline Pleasants & 215.00 & 211.00 & $(4.00)$ & -1.86 \\
\hline Pocahontas & 223.51 & 205.27 & $(18.24)$ & -8.16 \\
\hline Preston & 760.07 & 656.30 & $(103.77)$ & -13.65 \\
\hline Putnam & 899.50 & $1,027.00$ & 127.50 & 14.17 \\
\hline Raleigh & 1.803 .00 & 1.656 .50 & $(146.50)$ & -8.13 \\
\hline Randolph & 684.50 & 624.00 & $(60.50)$ & -8.84 \\
\hline Ritchie & 236.50 & 250.18 & 13.68 & 5.78 \\
\hline Roane & 384.40 & 379.50 & $(4.90)$ & -1.27 \\
\hline Summers & 302.44 & 234.50 & (67.94) & -22.46 \\
\hline Taylor & 380.50 & 344.50 & $(36.00)$ & -9.46 \\
\hline Tucker & 193.00 & 174.50 & (18.50) & -9.59 \\
\hline Tyler & 255.00 & 214.50 & $(40.50)$ & -15.88 \\
\hline Upshur & 553.60 & 522.90 & $(30.70)$ & -5.55 \\
\hline Wayne & 1.060 .40 & 1.015 .00 & $(45.40)$ & -4.28 \\
\hline Webster & 325.60 & 252.40 & $(73.20)$ & -22.48 \\
\hline Wetzel & 487.95 & 448.50 & $(39.45)$ & -8.08 \\
\hline Wirt & 135.50 & 144.00 & 8.50 & 6.27 \\
\hline Wood & $1,994.50$ & $1,768.90$ & $(225.60)$ & -11.31 \\
\hline Wyoming & 921.50 & 685.50 & $(236.00)$ & -25.61 \\
\hline State & $41,415.34$ & $38,101.44$ & $(3,313.90)$ & -8.00 \\
\hline
\end{tabular}


Table A-4

Comparison of Number of Professional Personnel Employed (All Funding Sources) Per District Between School Years 1987-1988 and 1996-1997

\begin{tabular}{|c|c|c|c|c|}
\hline \multirow[b]{2}{*}{ County } & \multicolumn{2}{|c|}{ School Year } & \multirow{2}{*}{$\begin{array}{l}\text { Increase } \\
\text { (Decrease) }\end{array}$} & \multirow{2}{*}{$\begin{array}{l}\text { Percent } \\
\text { Change }\end{array}$} \\
\hline & $1987-1988$ & $1996-1997$ & & \\
\hline Barbour & 233.00 & 223.60 & $(9.40)$ & -4.03 \\
\hline Berkeley & 768.73 & 909.51 & 140.78 & 18.31 \\
\hline Boone & 464.00 & 421.00 & $(43.00)$ & -9.27 \\
\hline Braxton & 261.50 & 229.36 & (32.14) & -12.29 \\
\hline Brooke & 385.00 & 329.50 & $(55.50)$ & -14.42 \\
\hline Cabell & $1,245.46$ & $1,167.30$ & (78.16) & -6.28 \\
\hline Calhoun & 156.16 & 134.50 & (21.66) & -13.87 \\
\hline Clay & 169.50 & 163.88 & $(5.62)$ & -3.32 \\
\hline Doddridge & 111.50 & 110.50 & $(1.00)$ & -0.90 \\
\hline Fayette & 765.86 & 671.50 & $(94.36)$ & -12.32 \\
\hline Gilmer & 112.38 & 98.50 & (13.88) & -12.35 \\
\hline Grant & 164.00 & 150.00 & (14.00) & -8.54 \\
\hline Greenbrier & 488.80 & 442.14 & (46.66) & -9.55 \\
\hline Hampshire & 220.00 & 257.50 & 37.50 & 17.05 \\
\hline Hancock & 435.00 & 383.50 & $(51.50)$ & -11.84 \\
\hline Hardy & 148.50 & 151.35 & 2.85 & 1.92 \\
\hline Harrison & $1,013.11$ & 955.80 & $(57.31)$ & -5.66 \\
\hline Jackson & 418.10 & 410.92 & (7.18) & -1.72 \\
\hline Jefferson & 443.00 & 491.00 & 48.00 & 10.84 \\
\hline Kanawha & $2,830.00$ & $2,556.68$ & $(273.32)$ & -9.66 \\
\hline Lewis & 257.00 & 238.00 & (19.00) & -7.39 \\
\hline Lincoln & 397.67 & 361.00 & (36.67) & -9.22 \\
\hline Logan & 750.00 & 590.50 & (159.50) & -21.27 \\
\hline Marion & 779.90 & 729.51 & $(50.39)$ & -6.46 \\
\hline Marshall & 535.00 & 467.50 & $(67.50)$ & -12.62 \\
\hline Mason & 377.00 & 389.50 & 12.50 & 3.32 \\
\hline Mercer & $1,004.50$ & 827.30 & $(177.20)$ & -17.64 \\
\hline Mineral & 408.50 & 381.67 & (26.83) & -6.57 \\
\hline Mingo & 609.00 & 552.00 & $(57.00)$ & -9.36 \\
\hline Monongalia & 763.77 & 818.38 & 54.61 & 7.15 \\
\hline Monroe & 181.45 & 154.30 & $(27.15)$ & -14.96 \\
\hline Morgan & 160.77 & 163.90 & 3.13 & 1.95 \\
\hline McDowell & 692.00 & 520.00 & (172.00) & -24.86 \\
\hline Nicholas & 430.06 & 409.50 & $(20.56)$ & -4.78 \\
\hline Ohio & 552.45 & 500.50 & (51.95) & -9.40 \\
\hline Pendleton & 124.50 & 113.50 & (11.00) & -8.84 \\
\hline Pleasants & 135.00 & 135.00 & 0.00 & 0.00 \\
\hline Pocahontas & 134.50 & 127.77 & $(6.73)$ & -5.00 \\
\hline Preston & 484.00 & 423.80 & $(60.20)$ & -12.44 \\
\hline Putnam & 585.00 & 662.50 & 77.50 & 13.25 \\
\hline Raleigh & $1,142.00$ & $1,059.00$ & $(83.00)$ & -7.27 \\
\hline Randolph & 446.50 & 406.00 & $(40.50)$ & -9.07 \\
\hline Ritchie & 147.00 & 153.68 & 6.68 & 4.54 \\
\hline Roane & 238.40 & 235.50 & $(2.90)$ & -1.22 \\
\hline Summers & 189.37 & 153.00 & $(36.37)$ & -19.21 \\
\hline Taylor & 234.00 & 221.50 & $(12.50)$ & -5.34 \\
\hline Tucker & 119.00 & 107.50 & (11.50) & -9.66 \\
\hline Tyler & 158.00 & 137.50 & $(20.50)$ & -12.97 \\
\hline Upshur & 346.60 & 331.40 & (15.20) & -4.39 \\
\hline Wayne & 662.90 & 640.50 & $(22.40)$ & -3.38 \\
\hline Webster & 197.60 & 160.40 & $(37.20)$ & -18.83 \\
\hline Wetzel & 320.45 & 296.00 & $(24.45)$ & -7.63 \\
\hline Wirt & 84.00 & 92.00 & 8.00 & 9.52 \\
\hline Wood & $1,302.50$ & $1,137.90$ & $(164.60)$ & -12.64 \\
\hline Wyoming & 577.50 & 438.50 & $(139.00)$ & -24.07 \\
\hline State & $26,361.49$ & $24,394.55$ & $(1,966.94)$ & -7.46 \\
\hline
\end{tabular}


Table A-5

Comparison of Number of Service Personnel Employed (All Funding Sources)

Per District Between School Years 1987-1988 and 1996-1997

\begin{tabular}{|c|c|c|c|c|}
\hline \multirow[b]{2}{*}{ County } & \multicolumn{2}{|c|}{ School Year } & \multirow{2}{*}{$\begin{array}{c}\text { Increase } \\
\text { (Decrease) }\end{array}$} & \multirow{2}{*}{$\begin{array}{l}\text { Percent } \\
\text { Change }\end{array}$} \\
\hline & $1987-1988$ & 1996-1997 & & \\
\hline Barbour & 142.03 & 125.00 & (17.03) & -11.99 \\
\hline Berkeley & 413.00 & 545.39 & 132.39 & 32.06 \\
\hline Boone & 280.00 & 228.50 & $(51.50)$ & -18.39 \\
\hline Braxton & 142.60 & 121.00 & (21.60) & -15.15 \\
\hline Brooke & 210.55 & 169.00 & (41.55) & -19.73 \\
\hline Cabell & 635.50 & 623.00 & (12.50) & -1.97 \\
\hline Calhoun & 85.50 & 77.00 & $(8.50)$ & -9.94 \\
\hline Clay & 126.50 & 116.50 & (10.00) & -7.91 \\
\hline Doddridge & 87.50 & 71.00 & (16.50) & -18.86 \\
\hline Fayette & 423.50 & 372.50 & $(51.00)$ & -12.04 \\
\hline Gilmer & 76.50 & 59.50 & (17.00) & -22.22 \\
\hline Grant & 104.39 & 88.00 & (16.39) & -15.70 \\
\hline Greenbrier & 269.01 & 273.00 & 3.99 & 1.48 \\
\hline Hampshire & 138.02 & 146.00 & 7.98 & 5.78 \\
\hline Hancock & 217.50 & 212.00 & $(5.50)$ & -2.53 \\
\hline Hardy & 92.00 & 79.50 & (12.50) & -13.59 \\
\hline Harrison & 528.02 & 520.00 & $(8.02)$ & -1.52 \\
\hline Jackson & 230.00 & 231.50 & 1.50 & 0.65 \\
\hline Jefferson & 234.00 & 273.50 & 39.50 & 16.88 \\
\hline Kanawha & $1,524.50$ & $1,331.00$ & (193.50) & -12.69 \\
\hline Lewis & 149.00 & 137.00 & (12.00) & -8.05 \\
\hline Lincoln & 252.55 & 218.00 & (34.55) & -13.68 \\
\hline Logan & 495.50 & 356.00 & (139.50) & -28.15 \\
\hline Marion & 418.53 & 405.00 & (13.53) & -3.23 \\
\hline Marshall & 279.00 & 263.50 & (15.50) & -5.56 \\
\hline Mason & 229.50 & 213.50 & (16.00) & -6.97 \\
\hline Mercer & 591.50 & 466.50 & $(125.00)$ & -21.13 \\
\hline Mineral & 238.50 & 215.50 & $(23.00)$ & -9.64 \\
\hline Mingo & 383.00 & 298.00 & $(85.00)$ & -22.19 \\
\hline Monongalia & 412.00 & 446.50 & 34.50 & 8.37 \\
\hline Monroe & 109.00 & 100.50 & $(8.50)$ & -7.80 \\
\hline Morgan & 95.50 & 97.50 & 2.00 & 2.09 \\
\hline McDowell & 513.00 & 338.50 & $(174.50)$ & -34.02 \\
\hline Nicholas & 260.50 & 245.50 & (15.00) & -5.76 \\
\hline Ohio & 278.00 & 280.00 & 2.00 & 0.72 \\
\hline Pendleton & 76.00 & 67.00 & $(9.00)$ & -11.84 \\
\hline Pleasants & 80.00 & 76.00 & $(4.00)$ & -5.00 \\
\hline Pocahontas & 89.01 & 77.50 & (11.51) & -12.93 \\
\hline Preston & 276.07 & 232.50 & (43.57) & -15.78 \\
\hline Putnam & 314.50 & 364.50 & 50.00 & 15.90 \\
\hline Raleigh & 661.00 & 597.50 & $(63.50)$ & -9.61 \\
\hline Randolph & 238.00 & 218.00 & $(20.00)$ & -8.40 \\
\hline Ritchie & 89.50 & 96.50 & 7.00 & 7.82 \\
\hline Roane & 146.00 & 144.00 & $(2.00)$ & -1.37 \\
\hline Summers & 113.07 & 81.50 & (31.57) & -27.92 \\
\hline Taylor & 146.50 & 123.00 & $(23.50)$ & -16.04 \\
\hline Tucker & 74.00 & 67.00 & $(7.00)$ & -9.46 \\
\hline Tyler & 97.00 & 77.00 & $(20.00)$ & -20.62 \\
\hline Upshur & 207.00 & 191.50 & (15.50) & -7.49 \\
\hline Wayne & 397.50 & 374.50 & $(23.00)$ & -5.79 \\
\hline Webster & 128.00 & 92.00 & $(36.00)$ & -28.13 \\
\hline Wetzel & 167.50 & 152.50 & (15.00) & -8.96 \\
\hline Wirt & 51.50 & 52.00 & 0.50 & 0.97 \\
\hline Wood & 692.00 & 631.00 & (61.00) & -8.82 \\
\hline Wyoming & 344.00 & 247.00 & $(97.00)$ & -28.20 \\
\hline State & $15,053.85$ & $13,706.89$ & $(1,346.96)$ & -8.95 \\
\hline
\end{tabular}


Table A-6

Comparison of Total Number of Personnel Allowed in Formula

Per District Between School Years 1987-1988 and 1996-1997

\begin{tabular}{|c|c|c|c|c|}
\hline \multirow[b]{2}{*}{ County } & \multicolumn{2}{|c|}{ School Year } & \multirow{2}{*}{$\begin{array}{l}\text { Increase } \\
\text { (Decrease) }\end{array}$} & \multirow{2}{*}{$\begin{array}{l}\text { Percent } \\
\text { Change }\end{array}$} \\
\hline & $1987-1988$ & $1996-1997$ & & \\
\hline Barbour & 365.406 & 324.192 & $(41.21)$ & -11.28 \\
\hline Berkeley & $1,054.177$ & $1,290.403$ & 236.23 & 22.41 \\
\hline Boone & 689.382 & 568.009 & (121.37) & -17.61 \\
\hline Braxton & 385.134 & 318.599 & $(66.54)$ & $\begin{array}{l}-17.28 \\
\end{array}$ \\
\hline Brooke & 595.844 & 467.617 & $(128.23)$ & -21.52 \\
\hline Cabell & 1.840 .385 & 1.618 .925 & $(221.46)$ & -12.03 \\
\hline Calhoun & 235.240 & 197.448 & $(37.79)$ & -16.07 \\
\hline Clay & 264.752 & 249.272 & (15.48) & -5.85 \\
\hline Doddridge & 163.679 & 156.694 & (6.99) & -4.27 \\
\hline Fayette & $1,139.675$ & 957.861 & (181.81) & -15.95 \\
\hline Gilmer & 167.685 & 141.214 & (26.47) & -15.79 \\
\hline Grant & 247.713 & 226.822 & (20.89) & -8.43 \\
\hline Greenbrier & 723.130 & 665.128 & $(58.00)$ & -8.02 \\
\hline Hampshire & 327.311 & 375.916 & 48.61 & 14.85 \\
\hline Hancock & 633.664 & 556.267 & $(77.40)$ & -12.21 \\
\hline Hardy & 221.457 & 224.336 & 2.88 & 1.30 \\
\hline Harrison & $1,487.263$ & $1,398.681$ & $(88.58)$ & -5.96 \\
\hline Jackson & 638.361 & 613.004 & $(25.36)$ & -3.97 \\
\hline Jefferson & 639.289 & 736.886 & 97.60 & 15.27 \\
\hline Kanawha & $4,147.882$ & $3,680.716$ & $(467.17)$ & -11.26 \\
\hline Lewis & 389.098 & 335.111 & $(53.99)$ & -13.87 \\
\hline Lincoln & 593.724 & 508.790 & $(84.93)$ & -14.31 \\
\hline Logan & $1,141.786$ & 865.611 & (276.18) & -24.19 \\
\hline Marion & $1,165.082$ & $1,034.701$ & (130.38) & -11.19 \\
\hline Marshall & 815.282 & 681.325 & (133.96) & -16.43 \\
\hline Mason & 564.488 & 536.240 & $(28.25)$ & -5.00 \\
\hline Mercer & $1,489.240$ & $1,169.125$ & (320.12) & -21.50 \\
\hline Mineral & 633.228 & 554.500 & (78.73) & -12.43 \\
\hline Mingo & 919.642 & 749.598 & $(170.04)$ & -18.49 \\
\hline Monongalia & $1,160.203$ & $1,146.322$ & (13.88) & -1.20 \\
\hline Monroe & 270.204 & 221.626 & (48.58) & -17.98 \\
\hline Morgan & 247.373 & 246.869 & $(0.50)$ & -0.20 \\
\hline McDowell & $1,086.334$ & 745.268 & $(341.07)$ & -31.40 \\
\hline Nicholas & 647.945 & 591.443 & $(56.50)$ & -8.72 \\
\hline Ohio & 802.935 & 718.292 & (84.64) & -10.54 \\
\hline Pendleton & 189.704 & 167.299 & $(22.41)$ & -11.81 \\
\hline Pleasants & 188.042 & 174.864 & (13.18) & -7.01 \\
\hline Pocahontas & 204.260 & 183.500 & (20.76) & -10.16 \\
\hline Preston & 726.367 & 609.472 & (116.90) & -16.09 \\
\hline Putnam & 871.342 & 992.970 & 121.63 & 13.96 \\
\hline Raleigh & $1,699.048$ & 1.527 .471 & $(171.58)$ & -10.10 \\
\hline Randolph & 658.313 & 583.143 & $(75.17)$ & -11.42 \\
\hline Ritchie & 228.484 & 212.587 & (15.90) & -6.96 \\
\hline Roane & 367.573 & 348.802 & (18.77) & -5.11 \\
\hline Summers & 286.140 & 222.651 & (63.49) & -22.19 \\
\hline Taylor & 365.785 & 322.647 & $(43.14)$ & -11.79 \\
\hline Tucker & 184.942 & 159.033 & $(25.91)$ & -14.01 \\
\hline Tyler & 253.204 & 197.588 & $(55.62)$ & -21.96 \\
\hline Upshur & 542.320 & 480.523 & $(61.80)$ & -11.39 \\
\hline Wayne & 979.870 & 892.231 & (87.64) & -8.94 \\
\hline Webster & 295.836 & 226.606 & $(69.23)$ & -23.40 \\
\hline Wetzel & 475.803 & 439.903 & (35.90) & -7.55 \\
\hline Wirt & 131.186 & 138.464 & 7.28 & 5.55 \\
\hline Wood & $1,968.821$ & $1,683.353$ & $(285.47)$ & -14.50 \\
\hline Wyoming & 885.194 & 641.819 & $(243.38)$ & -27.49 \\
\hline State & $39,396.227$ & $35,077.737$ & $(4,318.49)$ & -10.96 \\
\hline
\end{tabular}


Table A-7

Comparison of Number of Professional Educators Allowed in Formula Per District Between School Years 1987-1988 and 1996-1997

\begin{tabular}{|c|c|c|c|c|}
\hline \multirow[b]{2}{*}{ County } & \multicolumn{2}{|c|}{ School Year } & \multirow{2}{*}{$\begin{array}{l}\text { Increase } \\
\text { (Decrease) }\end{array}$} & \multirow{2}{*}{$\begin{array}{l}\text { Percent } \\
\text { Change }\end{array}$} \\
\hline & $1987-1988$ & 1996-1997 & & \\
\hline Barbour & 225.15 & 200.91 & (24.24) & -10.77 \\
\hline Berkeley & 672.72 & 798.91 & 126.19 & 18.76 \\
\hline Boone & 427.52 & 355.34 & (72.18) & -16.88 \\
\hline Braxton & 241.40 & 200.54 & (40.86) & -16.93 \\
\hline Brooke & 372.13 & 293.18 & (78.95) & -21.22 \\
\hline Cabell & 1.154 .95 & 1.014 .77 & $(140.18)$ & -12.14 \\
\hline Calhoun & 147.45 & 125.07 & $(22.38)$ & -15.18 \\
\hline Clay & 161.50 & 154.79 & (6.71) & -4.15 \\
\hline Doddridge & 100.72 & 98.46 & (2.26) & -2.24 \\
\hline Fayette & 715.88 & 596.49 & $(119.39)$ & -16.68 \\
\hline Gilmer & 102.36 & 86.75 & (15.61) & -15.25 \\
\hline Grant & 155.34 & 142.22 & $(13.12)$ & -8.45 \\
\hline Greenbrier & 446.88 & 409.97 & (36.91) & -8.26 \\
\hline Hampshire & $\begin{array}{l}440.00 \\
203.12\end{array}$ & 232.88 & 29.76 & $\begin{array}{l}-0.20 \\
14.65\end{array}$ \\
\hline Hancock & 404.36 & 344.38 & $(59.98)$ & -14.83 \\
\hline Hardy & 136.44 & 140.86 & 4.42 & 3.24 \\
\hline Harrison & 928.79 & 876.11 & $(52.68)$ & -5.67 \\
\hline Jackson & 399.10 & 387.47 & (11.63) & -2.91 \\
\hline Jefferson & 413.23 & 460.09 & 46.86 & 11.34 \\
\hline Kanawha & 2.571 .20 & $2,283.01$ & (288.19) & -11.21 \\
\hline Lewis & 239.45 & 210.59 & $(28.86)$ & -12.05 \\
\hline Lincoln & 366.91 & 320.43 & (46.48) & -12.67 \\
\hline Logan & 705.60 & 536.54 & $(169.06)$ & -23.96 \\
\hline Marion & 731.01 & 636.63 & $(94.38)$ & -12.91 \\
\hline Marshall & 511.12 & 429.09 & (82.03) & -16.05 \\
\hline Mason & 350.09 & 335.24 & $(14.85)$ & -4.24 \\
\hline Mercer & 925.65 & 724.26 & (201.39) & -21.76 \\
\hline Mineral & 396.50 & 345.10 & (51.40) & -12.96 \\
\hline Mingo & 568.32 & 463.99 & $(104.33)$ & -18.36 \\
\hline Monongalia & 723.69 & 702.57 & $(21.12)$ & -2.92 \\
\hline Monroe & 166.98 & 137.28 & $(29.70)$ & -17.79 \\
\hline Morgan & 152.69 & 151.71 & $(0.98)$ & -0.64 \\
\hline McDowell & 671.33 & 469.36 & (201.97) & -30.09 \\
\hline Nicholas & 406.45 & 369.78 & $(36.67)$ & $\begin{array}{r}-50.09 \\
-9.02\end{array}$ \\
\hline Ohio & 509.95 & 443.46 & (66.49) & -13.04 \\
\hline Pendleton & 116.79 & 104.58 & $(12.21)$ & -10.45 \\
\hline Pleasants & 117.83 & 110.48 & $(7.35)$ & -6.24 \\
\hline Pocahontas & 126.23 & 115.51 & $(10.72)$ & -8.49 \\
\hline Preston & 449.57 & 383.25 & (66.32) & -14.75 \\
\hline Putnam & 551.21 & 623.25 & 72.04 & 13.07 \\
\hline Raleigh & 1.063 .65 & 951.31 & (112.34) & -10.56 \\
\hline Randolph & 420.92 & 365.65 & $(55.27)$ & -13.13 \\
\hline Ritchie & 140.30 & 133.67 & (6.63) & -4.73 \\
\hline Roane & 232.40 & 218.36 & (14.04) & -6.04 \\
\hline Summers & 176.83 & 139.19 & (37.64) & -21.29 \\
\hline Taylor & 225.60 & 203.07 & (22.53) & -9.99 \\
\hline Tucker & 114.29 & 99.83 & (14.46) & -12.65 \\
\hline Tyler & 155.75 & 124.70 & (31.05) & -19.94 \\
\hline Upshur & 340.39 & 298.94 & $(41.45)$ & -12.18 \\
\hline Wayne & 607.04 & 557.63 & (49.41) & -8.14 \\
\hline Webster & 182.82 & 142.09 & (40.73) & -22.28 \\
\hline Wetzel & 300.90 & 276.48 & $(24.42)$ & -8.12 \\
\hline Wirt & 81.07 & 86.00 & 4.93 & 6.08 \\
\hline Wood & $1,236.68$ & $1,044.86$ & (191.82) & -15.51 \\
\hline Wyoming & 547.03 & 399.10 & $(147.93)$ & -27.04 \\
\hline State & $24,593.28$ & $21,856.18$ & $(2,737.10)$ & -11.13 \\
\hline
\end{tabular}


Table A-8

Comparison of Number of Service Personnel Allowed in Formula

Per District Between School Years 1987-1988 and 1996-1997

\begin{tabular}{|c|c|c|c|c|}
\hline \multirow[b]{2}{*}{ County } & \multicolumn{2}{|c|}{ School Year } & \multirow{2}{*}{$\begin{array}{l}\text { Increase } \\
\text { (Decrease) }\end{array}$} & \multirow{2}{*}{$\begin{array}{l}\text { Percent } \\
\text { Change }\end{array}$} \\
\hline & $1987-1988$ & $1996-1997$ & & \\
\hline Barbour & 140.256 & 123.282 & (16.97) & -12.10 \\
\hline Berkeley & 381.457 & 491.493 & 110.04 & 28.85 \\
\hline Boone & 261.862 & 212.669 & $(49.19)$ & -18.79 \\
\hline Braxton & 143.734 & 118.059 & (25.68) & -17.86 \\
\hline Brooke & 223.714 & 174.437 & $(49.28)$ & -22.03 \\
\hline Cabell & 685.435 & 604.155 & $(81.28)$ & -11.86 \\
\hline Calhoun & 87.790 & 72.378 & $(15.41)$ & -17.56 \\
\hline Clay & 103.252 & 94.482 & $(8.77)$ & -8.49 \\
\hline Doddridge & 62.959 & 58.234 & (4.73) & -7.50 \\
\hline Fayette & 423.795 & 361.371 & $(62.42)$ & -14.73 \\
\hline Gilmer & 65.325 & 54.464 & $(10.86)$ & -16.63 \\
\hline Grant & 92.373 & 84.602 & $(7.77)$ & -8.41 \\
\hline Greenbrier & 276.250 & 255.158 & (21.09) & -7.64 \\
\hline Hampshire & 124.191 & 143.036 & 18.85 & 15.17 \\
\hline Hancock & 229.304 & 211.887 & $(17.42)$ & -7.60 \\
\hline Hardy & 85.017 & 83.476 & (1.54) & -1.81 \\
\hline Harrison & 558.473 & 522.571 & $(35.90)$ & -6.43 \\
\hline Jackson & 239.261 & 225.534 & (13.73) & -5.74 \\
\hline Jefferson & 226.059 & 276.796 & 50.74 & 22.44 \\
\hline Kanawha & $1,576.682$ & $1,397.706$ & (178.98) & -11.35 \\
\hline Lewis & 149.648 & 124.521 & $(25.13)$ & $\begin{array}{l}-16.79 \\
\end{array}$ \\
\hline Lincoln & 226.814 & 188.360 & (38.45) & -16.95 \\
\hline Logan & 436.186 & 329.071 & (107.12) & -24.56 \\
\hline Marion & 434.072 & 398.071 & (36.00) & -8.29 \\
\hline Marshall & 304.162 & 252.235 & (51.93) & -17.07 \\
\hline Mason & 214.398 & 201.000 & (13.40) & -6.25 \\
\hline Mercer & 563.590 & 444.865 & (118.73) & -21.07 \\
\hline Mineral & 236.728 & 209.400 & (27.33) & -11.54 \\
\hline Mingo & 351.322 & 285.608 & $(65.71)$ & -18.70 \\
\hline Monongalia & 436.513 & 443.752 & 7.24 & 1.66 \\
\hline Monroe & 103.224 & 84.346 & (18.88) & $\begin{array}{l}-18.29 \\
-\end{array}$ \\
\hline Morgan & 94.683 & 95.159 & 0.48 & 0.50 \\
\hline McDowell & 415.004 & 275.908 & (139.10) & -33.52 \\
\hline Nicholas & 241.495 & 221.663 & (19.83) & -8.21 \\
\hline Ohio & 292.985 & 274.832 & (18.15) & -6.20 \\
\hline Pendleton & 72.914 & 62.719 & $(10.20)$ & -13.98 \\
\hline Pleasants & 70.212 & 64.384 & (5.83) & -8.30 \\
\hline Pocahontas & 78.030 & 67.990 & (10.04) & -12.87 \\
\hline Preston & 276.797 & 226.222 & $(50.58)$ & -18.27 \\
\hline Putnam & 320.132 & 369.720 & 49.59 & 15.49 \\
\hline Raleigh & 635.398 & 576.161 & $(59.24)$ & -9.32 \\
\hline Randolph & 237.393 & 217.493 & (19.90) & -8.38 \\
\hline Ritchie & 88.184 & 78.917 & $(9.27)$ & -10.51 \\
\hline Roane & 135.173 & 130.442 & (4.73) & -3.50 \\
\hline Summers & 109.310 & 83.461 & $(25.85)$ & -23.65 \\
\hline Taylor & 140.185 & 119.577 & $(20.61)$ & -14.70 \\
\hline Tucker & 70.652 & 59.203 & (11.45) & -16.20 \\
\hline Tyler & 97.454 & 72.888 & (24.57) & -25.21 \\
\hline Upshur & 201.930 & 181.583 & (20.35) & -10.08 \\
\hline Wayne & 372.830 & 334.601 & (38.23) & -10.25 \\
\hline Webster & 113.016 & 84.516 & $(28.50)$ & -25.22 \\
\hline Wetzel & 174.903 & 163.423 & (11.48) & -6.56 \\
\hline Wirt & 50.116 & 52.464 & 2.35 & 4.69 \\
\hline Wood & 732.141 & 638.493 & (93.65) & -12.79 \\
\hline Wyoming & 338.164 & 242.719 & $(95.45)$ & -28.22 \\
\hline State & $14,802.947$ & $13,221.557$ & $(1,581.39)$ & -10.68 \\
\hline
\end{tabular}


Table A-9 (Page 1)

Unreserved Fund Balance

General Current Expense Fund

Fiscal Years Ending (FYE) 6-30-1988 through 6-30-1999

\begin{tabular}{|c|c|c|c|c|c|c|}
\hline County & $\begin{array}{c}\text { FYE } \\
6-30-1988\end{array}$ & $\begin{array}{c}\text { FYE } \\
6-30-1989\end{array}$ & $\begin{array}{c}\text { FYE } \\
6-30-1990\end{array}$ & $\begin{array}{c}\text { FYE } \\
6-30-1991\end{array}$ & $\begin{array}{c}\text { FYE } \\
6-30-1992\end{array}$ & $\begin{array}{c}\text { FYE } \\
6-30-1993\end{array}$ \\
\hline Barbour & 298,243 & $(164,644)$ & 12,732 & $(3,978)$ & $(46,820)$ & 185 \\
\hline Berkeley & $(141,768)$ & $(2,295,829)^{*}$ & $(2,422,526)^{*}$ & 35,229 & 278,669 & 929,148 \\
\hline Boone & 461,155 & 378,957 & $1,153,432$ & $1,665,269$ & $1,884,154$ & $(229,639)$ \\
\hline Braxton & 177,965 & 199,259 & 193,867 & 134,033 & 37,475 & $(36,508)$ \\
\hline Brooke & 747,705 & 544,080 & 441,185 & $1,029,461$ & 921,597 & 406,841 \\
\hline Cabell & $3,075,971$ & $2,329,004$ & $2,523,571$ & $2,071,561$ & $1,791,882$ & $2,148,756$ \\
\hline Calhoun & 362,334 & 256,189 & 7,682 & $(13,535)$ & 43,296 & 52,962 \\
\hline Clay & 6,381 & $(18,308)$ & $(45,559)$ & $(14,451)$ & $(22,766)$ & $(253,109)$ \\
\hline Doddridge & 463,303 & 217,292 & 210,962 & 172,406 & 171,111 & $(98,366)$ \\
\hline Fayette & $4,246,111$ & $2,557,627$ & $3,811,429$ & $5,570,050$ & $2,046,902$ & $1,502,508$ \\
\hline Gilmer & $(173,209)$ & 128,172 & 113,703 & 50,844 & 99,643 & $(26,960)$ \\
\hline Grant & 204,907 & 143,549 & 464,499 & 173,002 & 113,779 & 41,688 \\
\hline Greenbrier & $1,046,802$ & 810,080 & 260,864 & 258,820 & $(423,232)$ & $(739,828)$ \\
\hline Hampshire & 95,720 & 51,736 & 157,962 & 35,486 & 12,841 & $(81,917)$ \\
\hline Hancock & 195,541 & 787,595 & 780,602 & 102,374 & 394,978 & 27,702 \\
\hline Hardy & 285,005 & 427,689 & 446,745 & 399,769 & 130,018 & $(19,292)$ \\
\hline Harrison & 244,239 & 270,447 & 559,503 & $(169,458)$ & 79,960 & 91,094 \\
\hline Jackson & 189,831 & 237,101 & 538,589 & 928,843 & 451,165 & 607,204 \\
\hline Jefferson & 414,016 & 306,929 & 652,493 & 225,914 & 800,657 & 476,764 \\
\hline Kanawha & 509,412 & $(649,741)$ & $(2,283,400)$ & $(2,644,585)$ & $(623,696)$ & $(147,389)$ \\
\hline Lewis & 996,442 & 759,336 & 109,972 & 108,387 & 400,069 & 344,237 \\
\hline Lincoln & 342,169 & 370,652 & 412,058 & 480,279 & 248,293 & 85,485 \\
\hline Logan & 454,211 & 23,661 & 265,036 & $(7,497)$ & $(200,094)$ & 201,797 \\
\hline Marion & 594,244 & 436,032 & 271,913 & $1,413,664$ & 131,431 & 186,411 \\
\hline Marshall & 890,213 & 868,892 & 949,208 & 929,132 & 690,142 & 83,979 \\
\hline Mason & 245,541 & 773,886 & $1,092,838$ & 739,260 & 469,591 & 150,559 \\
\hline Mercer & $1,910,727$ & $1,358,649$ & $1,423,892$ & $(23,681)$ & $(859,392)$ & 77,346 \\
\hline Mineral & 293,763 & 252,565 & 64,907 & $1,061,248$ & 522,431 & 13,545 \\
\hline Mingo & 317,379 & 583,845 & $1,458,525$ & 937,610 & 618,817 & 349,014 \\
\hline Monongalia & $1,438,628$ & 785,672 & 739,894 & 399,417 & $1,174,968$ & $1,265,019$ \\
\hline Monroe & 254,536 & 96,403 & 474,732 & 243,437 & 103,311 & 10,293 \\
\hline Morgan & 324,615 & 305,364 & 413,857 & 441,549 & 419,799 & 645,155 \\
\hline McDowell & 321,670 & 779,253 & 754,891 & $1,532,500$ & $1,134,281$ & 609,372 \\
\hline Nicholas & $1,667,421$ & 730,736 & $1,145,850$ & 880,179 & $(33,432)$ & $(564,105)$ \\
\hline Ohio & 813,212 & 815,326 & 808,354 & 542,683 & 431,080 & 405,882 \\
\hline Pendleton & 244,110 & 306,959 & 113,395 & 20,649 & 27,760 & $(164,038)$ \\
\hline Pleasants & 472,094 & 168,756 & 116,876 & 53,213 & 63,229 & 156,736 \\
\hline Pocahontas & 867,361 & 599,490 & 389,495 & 489,419 & 149,129 & 168,665 \\
\hline Preston & $(22,452)$ & 69,652 & 251,239 & 117,713 & 94,039 & $(106,212)$ \\
\hline Putnam & $1,989,784$ & $1,170,732$ & $1,901,520$ & $1,416,406$ & $1,800,735$ & $2,290,204$ \\
\hline Raleigh & $1,137,389$ & $(23,898)$ & $1,341,405$ & $1,043,480$ & $(63,798)$ & 15,173 \\
\hline Randolph & 648,326 & 244,841 & 262,533 & 960,520 & $1,116,762$ & 331,865 \\
\hline Ritchie & 4,460 & $(335,637)$ & 50,511 & 21,120 & 163,312 & 312,986 \\
\hline Roane & 164,442 & 96,428 & 62,776 & 58,416 & 5,419 & 3,709 \\
\hline Summers & 142,353 & 61,682 & 65,825 & $(250,344)$ & $(246,474)$ & $(373,899)$ \\
\hline Taylor & $(39,530)$ & $(340,437)$ & $(484,058)^{*}$ & $(860,729) *$ & $(90,484)$ & 228,503 \\
\hline Tucker & 122,257 & 89,997 & 110,342 & $(187,151)$ & $(30,614)$ & 780 \\
\hline Tyler & 233,261 & 161,139 & 358,025 & 656,083 & 610,702 & 431,115 \\
\hline Upshur & $1,712,197$ & $1,252,495$ & $1,343,478$ & $1,294,603$ & $1,116,984$ & 691,718 \\
\hline Wayne & 80,298 & 50,960 & 728,614 & 456,532 & 806,410 & 483,401 \\
\hline Webster & 102,385 & 7,381 & 263,724 & $(87,847)$ & $(331,307)^{*}$ & 39,093 \\
\hline Wetzel & $(58,574)$ & 5,756 & 399,184 & 431,011 & 225,453 & 129,667 \\
\hline Wirt & 87,552 & 80,388 & 85,606 & 92,160 & 116,576 & 112,186 \\
\hline Wood & 272,269 & 378,675 & 64,339 & 69,613 & $(662,300)$ & $(1,597,034)$ \\
\hline Wyoming & 221,529 & 225,046 & $(562,353)$ & $(736,936)$ & $(695,299)$ & 174,628 \\
\hline Total & $31,955,946$ & $19,727,860$ & $24,826,737$ & $\underline{24,743,152}$ & $17,569,143$ & $11,845,079$ \\
\hline \# of Deficits & 5 & 7 & 5 & 12 & 14 & 14 \\
\hline
\end{tabular}

Notes: (1) The amounts presented are total unreserved fund balances, including unreserved-designated funds. (2) Amounts presented for fiscal years 1991 through 1998 are from audited financial statements except for Hampshire County. The amounts for FY99 are from unaudited statements and are subject to change. (3) Fund balances presented in bold with an asterisk represent deficit amounts that do not meet the definition of a "casual deficit." Beginning with FY98, a "casual deficit" is defined in West Virginia Code 18-1-1 as a deficit of not more than $3 \%$ of the approved levy estimate or that is nonrecurring. For previous years, only those deficits that exceeded $3 \%$ of the approved levy estimate are presented in bold. 
Table A-9 (Page 2)

Unreserved Fund Balance

General Current Expense Fund

Fiscal Years Ending (FYE) 6-30-1988 through 6-30-1999

\begin{tabular}{|c|c|c|c|c|c|c|}
\hline County & $\begin{array}{c}\text { FYE } \\
6-30-1994 \\
\end{array}$ & $\begin{array}{c}\text { FYE } \\
6-30-1995 \\
\end{array}$ & $\begin{array}{c}\text { FYE } \\
6-30-1996 \\
\end{array}$ & $\begin{array}{c}\text { FYE } \\
6-30-1997 \\
\end{array}$ & $\begin{array}{c}\text { FYE } \\
6-30-1998 \\
\end{array}$ & $\begin{array}{c}\text { FYE } \\
6-30-1999 \\
\end{array}$ \\
\hline Barbour & 83,395 & 102,066 & 24,601 & 105,603 & 244,751 & 601,352 \\
\hline Berkeley & $1,932,001$ & $1,382,162$ & 815,980 & $1,299,504$ & $1,602,500$ & $2,924,056$ \\
\hline Boone & $1,639,213$ & $5,974,728$ & $7,141,227$ & $6,610,151$ & $7,774,957$ & $6,926,417$ \\
\hline Braxton & $(331,067)$ & $(431,974)$ & $(39,920)$ & 41,443 & 171,916 & 320,005 \\
\hline Brooke & 321,727 & 353,377 & 373,078 & 141,786 & 222,354 & 398,141 \\
\hline Cabell & $3,716,556$ & $2,503,971$ & $3,158,925$ & $1,981,561$ & $1,260,534$ & $2,142,835$ \\
\hline Calhoun & 54,665 & 75,203 & 17,569 & 3,090 & 35,330 & 42,435 \\
\hline Clay & $(199,629)$ & $(214,171)$ & $(225,103)$ & $(180,410)$ & $(299,721)^{*}$ & $(25,601)^{\prime}$ \\
\hline Doddridge & $(201,395)$ & $(17,506)$ & $(113,100)$ & $(107,355)$ & 204,320 & 263,131 \\
\hline Fayette & $1,957,982$ & $1,292,468$ & $1,869,925$ & $2,043,619$ & $1,530,134$ & $1,869,540$ \\
\hline Gilmer & 174,344 & 206,719 & 86,346 & 122,715 & 176,807 & 480,781 \\
\hline Grant & $(138,335)$ & $(119,799)$ & $(170,386)$ & $(55,380)$ & 376,357 & 663,428 \\
\hline Greenbrier & $(637,891)$ & 88,173 & 356,316 & 844,279 & $1,546,265$ & $2,432,921$ \\
\hline Hampshire & 43,492 & 367,635 & 205,875 & 213,951 & 366,913 & 285,858 \\
\hline Hancock & 394,106 & 97,373 & 318,028 & 379,976 & $1,069,407$ & $2,163,066$ \\
\hline Hardy & $(214,169)$ & $(94,289)$ & 179,315 & 28,943 & 51,776 & $(292,935)$ \\
\hline Harrison & $(638,792)$ & $(778,841)$ & 199,692 & 51,016 & 192,446 & 968,985 \\
\hline Jackson & 838,926 & $1,609,415$ & $1,813,905$ & $1,076,090$ & $1,143,702$ & $1,629,165$ \\
\hline Jefferson & 94,720 & 210,085 & 836,955 & 419,779 & $3,295,698$ & $3,700,921$ \\
\hline Kanawha & $2,105,001$ & $4,133,377$ & $8,228,131$ & $6,967,733$ & $9,945,982$ & $10,766,823$ \\
\hline Lewis & 580,492 & 127,291 & $(1,240,937) *$ & $(796,518) *$ & 23,785 & 915,576 \\
\hline Lincoln & $(110,597)$ & $(361,635)$ & $(930,337)^{*}$ & $(254,021)$ & 202,697 & 915,970 \\
\hline Logan & 728,280 & 462,818 & $1,042,843$ & 942,749 & $1,001,944$ & 685,894 \\
\hline Marion & 38,723 & 33,744 & 168,835 & 592,404 & 798,536 & 274,048 \\
\hline Marshall & 432,026 & $1,463,424$ & $1,573,396$ & $1,257,963$ & $1,501,666$ & 879,399 \\
\hline Mason & $(39,866)$ & 237,247 & 517,103 & 327,550 & 860,763 & 894,753 \\
\hline Mercer & 21,750 & 330,755 & 460,854 & $1,623,051$ & $3,222,572$ & $2,893,886$ \\
\hline Mineral & 211,747 & 467,085 & 410,880 & 954,010 & 884,648 & 879,850 \\
\hline Mingo & $(1,940,640) *$ & $(4,310,836) *$ & $(3,868,626) *$ & $(2,377,448) *$ & 499,448 & $1,514,037$ \\
\hline Monongalia & $1,651,708$ & $1,670,397$ & $1,956,984$ & $1,453,794$ & $1,044,495$ & $2,116,873$ \\
\hline Monroe & $(117,769)$ & $(367,007)$ & $(592,145)^{*}$ & $(400,501)$ & $(166,691)^{*}$ & 37,891 \\
\hline Morgan & $1,076,531$ & $1,329,996$ & 906,053 & $1,151,063$ & $1,084,295$ & 635,703 \\
\hline McDowell & 515,682 & 42,489 & $(422,766)$ & 381,409 & $1,059,418$ & $2,201,818$ \\
\hline Nicholas & $(131,310)$ & $(526,827)$ & $(375,556)$ & 167,836 & 666,552 & 969,275 \\
\hline Ohio & 365,743 & 259,492 & 392,642 & 137,606 & 460,469 & 296,422 \\
\hline Pendleton & $(267,752) *$ & $(167,135)$ & $(46,180)$ & 31,929 & 12,363 & 121,001 \\
\hline Pleasants & 279,036 & 279,977 & 434,677 & 248,599 & 313,943 & 367,508 \\
\hline Pocahontas & 301,923 & 344,178 & 293,925 & 48,182 & 241,261 & 54,188 \\
\hline Preston & 591,802 & 26,753 & 271,149 & 189 & 613,743 & 325,801 \\
\hline Putnam & $2,318,674$ & $2,221,459$ & $1,894,512$ & $1,384,645$ & $1,750,257$ & $1,964,456$ \\
\hline Raleigh & 46,782 & 268,731 & $(223,897)$ & 520,743 & 648,958 & $2,387,006$ \\
\hline Randolph & $(416,836)$ & $(526,495)$ & 60,648 & 266,860 & $1,103,971$ & $1,388,952$ \\
\hline Ritchie & 136,646 & $(175,126)$ & $(441,369) *$ & $(449,582) *$ & $(37,294) *$ & 320,281 \\
\hline Roane & 1,500 & $(16,753)$ & 5,907 & 69,075 & 8,597 & 197,537 \\
\hline Summers & $(81,729)$ & $(281,949)$ & $(360,620)^{*}$ & $(83,662)$ & 275,204 & 317,964 \\
\hline Taylor & 484,601 & 628,172 & 567,722 & 525,015 & 446,997 & 338,268 \\
\hline Tucker & $(49,675)$ & $(96,433)$ & $(91,695)$ & 186,480 & 246,882 & 621,449 \\
\hline Tyler & 413,048 & 322,399 & 315,370 & 470,092 & 278,098 & 357,690 \\
\hline Upshur & 472,142 & 497,714 & 157,643 & $(228,239)$ & $(39,106) *$ & 372,117 \\
\hline Wayne & 362,210 & 609,515 & 6,684 & 57,070 & 923 & $(321,496)$ \\
\hline Webster & $(238,927)$ & $(273,386)$ & $(140,849)$ & 43,333 & 122,322 & 332,025 \\
\hline Wetzel & 607,131 & 215,995 & 477,597 & 623,562 & 428,610 & 446,904 \\
\hline Wirt & 114,667 & 164,668 & 150,179 & 163,501 & 325,766 & 473,425 \\
\hline Wood & 31,262 & 245,446 & 415,153 & 482,015 & $1,184,790$ & $1,706,440$ \\
\hline Wyoming & $1,080,526$ & $1,417,830$ & 496,719 & $1,591,079$ & $1,585,532$ & $1,407,629$ \\
\hline Total & $\underline{\underline{20,464,381}}$ & $\underline{\underline{23,304,165}}$ & $\underline{\underline{29,319,857}}$ & $\underline{\underline{33,099,927}}$ & $\underline{\underline{53,568,842}}$ & $\underline{\underline{67,551,864}}$ \\
\hline \# of Deficits & 17 & 17 & 16 & 10 & 4 & 3 \\
\hline
\end{tabular}

Notes: (1) The amounts presented are total unreserved fund balances, including unreserved-designated funds. (2) Amounts presented for fiscal years 1991 through 1998 are from audited financial statements except for Hampshire County. The amounts for FY99 are from unaudited statements and are subject to change. (3) Fund balances presented in bold with an asterisk represent deficit amounts that do not meet the definition of a "casual deficit." Beginning with FY98, a "casual deficit" is defined in West Virginia Code 18-1-1 as a deficit of not more than 3\% of the approved levy estimate or that is nonrecurring. For previous years, only those deficits that exceeded $3 \%$ of the approved levy estimate are presented in bold. 
Table A-10

County Boards of Education

Excess Levies in Effect

1996-1997 Year

\begin{tabular}{|c|c|c|c|c|c|c|}
\hline County & $\begin{array}{l}\text { Date of } \\
\text { Election }\end{array}$ & $\begin{array}{l}\text { Percent of } \\
\text { Votes for } \\
\text { Excess Levy }\end{array}$ & $\begin{array}{l}\text { Class I } \\
\text { Levy Rate } \\
\text { Per } \$ 100\end{array}$ & $\begin{array}{l}\text { Percent of } \\
\text { Maximum } \\
\quad(22.95)\end{array}$ & $\begin{array}{l}\text { Number } \\
\text { of Years }\end{array}$ & $\begin{array}{c}\text { Expiration } \\
\text { Date }\end{array}$ \\
\hline Barbour & --- & --- & --- & --- & - & --- \\
\hline Berkeley & $05-10-94$ & 56.0 & 22.50 & 98.0 & 4 & 06-30-99 \\
\hline Boone & $11-08-94$ & 64.9 & 22.95 & 100.0 & 5 & $06-30-00$ \\
\hline Braxton & --- & --- & --- & --- & - & -- \\
\hline Brooke & $10-30-93$ & 87.9 & 21.95 & 95.6 & 5 & 06-30-99 \\
\hline Cabell & $05-10-94$ & 59.9 & 22.95 & 100.0 & 5 & $06-30-00$ \\
\hline Calhoun & --- & --- & --- & --- & - & --- \\
\hline Clay & --- & --- & --- & & & \\
\hline Doddridge & $12-11-93$ & 85.6 & 22.95 & 100.0 & 3 & $06-30-97$ \\
\hline Fayette & $12-04-93$ & 75.0 & 22.95 & 100.0 & 5 & 06-30-99 \\
\hline Gilmer & $12-04-93$ & 64.0 & 7.97 & 34.7 & 3 & $06-30-97$ \\
\hline Grant & --- & --- & --- & --- & - & --- \\
\hline Greenbrier & $12-11-93$ & 69.1 & 11.48 & 50.0 & 5 & $06-30-99$ \\
\hline Hampshire & $12-14-91$ & 65.9 & 8.40 & 36.6 & 5 & $06-30-97$ \\
\hline Hancock & $10-30-93$ & 67.1 & 22.95 & 100.0 & 5 & $06-30-99$ \\
\hline Hardy & --- & --- & --- & --- & - & --- \\
\hline Harrison & $12-16-95$ & 73.9 & 20.66 & 90.0 & 5 & $06-30-01$ \\
\hline Jackson & $10-05-93$ & 80.3 & 22.95 & 100.0 & 5 & $06-30-99$ \\
\hline Jefferson & $11-03-92$ & 59.8 & 21.80 & 95.0 & 5 & $06-30-98$ \\
\hline Kanawha & $12-11-93$ & 52.0 & 21.34 & 93.0 & 5 & $06-30-99$ \\
\hline Lewis & $03-04-95$ & 72.2 & 13.54 & 59.0 & 5 & $06-30-00$ \\
\hline Lincoln & $02-19-94$ & 64.4 & 22.95 & 100.0 & 5 & $06-30-99$ \\
\hline Logan & $02-26-94$ & 53.5 & 21.70 & 94.6 & 5 & $06-30-99$ \\
\hline Marion & $12-18-93$ & 72.0 & 21.80 & 95.0 & 5 & $06-30-99$ \\
\hline Marshall & $12-18-92$ & 90.9 & 22.49 & 98.0 & 5 & $06-30-98$ \\
\hline Mason & $12-04-93$ & 57.0 & 20.89 & 91.0 & 5 & $06-30-99$ \\
\hline Mercer & $11-04-94$ & 57.0 & 22.95 & 100.0 & 5 & $06-30-00$ \\
\hline Mineral & $10-21-95$ & 73.6 & 22.95 & 100.0 & 5 & $06-30-01$ \\
\hline Mingo & $12-11-93$ & 59.5 & 22.95 & 100.0 & 5 & $06-30-99$ \\
\hline Monongalia & $02-26-94$ & 59.8 & 17.21 & 75.0 & 3 & $06-30-97$ \\
\hline Monroe & $03-18-95$ & 51.7 & 14.92 & 65.0 & 5 & $06-30-00$ \\
\hline Morgan & $12-11-93$ & 77.0 & 21.54 & 93.9 & 5 & $06-30-99$ \\
\hline McDowell & $02-08-94$ & 90.5 & 22.95 & 100.0 & 5 & $06-30-99$ \\
\hline Nicholas & $12-09-95$ & 81.1 & 10.00 & 43.6 & 5 & $06-30-01$ \\
\hline Ohio & $11-04-94$ & 62.1 & 21.62 & 94.2 & 5 & $06-30-00$ \\
\hline Pendleton & --- & --- & --- & --- & - & --- \\
\hline Pleasants & $09-25-93$ & 69.5 & 19.06 & 83.1 & 5 & 06-30-99 \\
\hline Pocahontas & --- & --- & --- & --- & - & --- \\
\hline Preston & --- & --- & --- & --- & - & --- \\
\hline Putnam & $02-13-96$ & 55.1 & 21.80 & 95.0 & 5 & $06-30-01$ \\
\hline Raleigh & $12-11-93$ & 61.6 & 22.26 & 97.0 & 5 & $06-30-99$ \\
\hline Randolph & -- & --- & --- & --- & - & --- \\
\hline Ritchie & $12-17-94$ & 58.0 & 14.92 & 65.0 & 3 & $06-30-00$ \\
\hline Roane & --- & --- & --- & --- & - & --- \\
\hline Summers & --- & --- & --- & --- & - & --- \\
\hline Taylor & $12-30-95$ & 77.5 & 11.48 & 50.0 & 5 & $06-30-01$ \\
\hline Tucker & --- & --- & --- & --- & - & --- \\
\hline Tyler & $09-22-92$ & 77.9 & 22.95 & 100.0 & 5 & 06-30-98 \\
\hline Upshur & & --- & --- & & & \\
\hline Wayne & $12-11-93$ & 79.2 & 22.95 & 100.0 & 5 & 06-30-99 \\
\hline Webster & --- & --- & --- & --- & - & --- \\
\hline Wetzel & $12-18-92$ & 81.0 & 22.95 & 100.0 & 5 & $06-30-98$ \\
\hline Wirt & $12-10-91$ & 80.7 & 20.66 & 90.0 & 5 & $06-30-97$ \\
\hline Wood & $11-02-93$ & 50.4 & 18.36 & 80.0 & 5 & $06-30-99$ \\
\hline Wyoming & $12-04-93$ & 68.0 & 22.95 & 100.0 & 5 & 06-30-99 \\
\hline State & 40 & 68.6 & 19.86 & 86.6 & 4.8 & \\
\hline
\end{tabular}


Table A-11

County Boards of Education

Excess Levies in Effect

1987-1988 Year

\begin{tabular}{|c|c|c|c|c|c|c|}
\hline County & $\begin{array}{l}\text { Date of } \\
\text { Election }\end{array}$ & $\begin{array}{l}\text { Percent of } \\
\text { Votes for } \\
\text { Excess Levy }\end{array}$ & $\begin{array}{c}\text { Class I } \\
\text { Levy Rate } \\
\text { Per } \$ 100\end{array}$ & $\begin{array}{l}\text { Percent of } \\
\text { Maximum } \\
(22.95)\end{array}$ & $\begin{array}{l}\text { Number } \\
\text { of Years }\end{array}$ & $\begin{array}{c}\text { Expiration } \\
\text { Date }\end{array}$ \\
\hline Barbour & --- & --- & --- & --- & - & --- \\
\hline Berkeley & $02-16-85$ & 77.0 & 20.00 & 87.2 & 3 & $06-30-88$ \\
\hline Boone & $06-05-84$ & 86.3 & 22.95 & 100.0 & 5 & $06-30-90$ \\
\hline Braxton & --- & --- & --- & --- & - & --- \\
\hline Brooke & $12-06-83$ & 85.0 & 22.95 & 100.0 & 5 & $06-30-89$ \\
\hline Cabell & $12-15-83$ & 86.0 & 22.95 & 100.0 & 5 & $06-30-90$ \\
\hline Calhoun & --- & --- & --- & --- & - & --- \\
\hline Clay & --- & --- & --- & --- & - & --- \\
\hline Doddridge & $02-19-85$ & 90.5 & 18.36 & 80.0 & 3 & $06-30-88$ \\
\hline Fayette & $10-19-83$ & 88.7 & 22.95 & 100.0 & 5 & $06-30-89$ \\
\hline Gilmer & $01-25-84$ & 69.0 & 16.07 & 70.0 & 5 & $06-30-89$ \\
\hline Grant & --- & --- & --- & --- & - & --- \\
\hline Greenbrier & $10-18-83$ & 85.8 & 11.48 & 50.0 & 5 & $06-30-89$ \\
\hline Hampshire & $05-13-86$ & 65.0 & 17.22 & 75.0 & 5 & $06-30-92$ \\
\hline Hancock & $09-30-83$ & 84.1 & 22.95 & 100.0 & 5 & $06-30-89$ \\
\hline Hardy & --- & --- & --- & --- & - & --- \\
\hline Harrison & $12-21-85$ & 88.0 & 22.95 & 100.0 & 5 & $06-30-91$ \\
\hline Jackson & $10-04-83$ & 85.9 & 22.95 & 100.0 & 5 & $06-30-89$ \\
\hline Jefferson & $11-04-86$ & 67.0 & 20.00 & 87.2 & 5 & $06-30-93$ \\
\hline Kanawha & $03-05-83$ & 88.6 & 22.95 & 100.0 & 5 & $06-30-89$ \\
\hline Lewis & $02-07-87$ & 89.3 & 11.48 & 50.0 & 3 & $06-30-90$ \\
\hline Lincoln & $01-07-84$ & 83.2 & 22.95 & 100.0 & 5 & $06-30-89$ \\
\hline Logan & $11-08-83$ & 66.0 & 22.95 & 100.0 & 5 & $06-30-89$ \\
\hline Marion & $05-24-83$ & 86.1 & 22.95 & 100.0 & 5 & $06-30-89$ \\
\hline Marshall & $12-14-82$ & 86.3 & 22.95 & 100.0 & 5 & $06-30-88$ \\
\hline Mason & $01-11-83$ & 72.3 & 22.95 & 100.0 & 5 & $06-30-88$ \\
\hline Mercer & $02-04-85$ & 77.2 & 22.95 & 100.0 & 5 & $06-30-90$ \\
\hline Mineral & $11-05-85$ & 61.7 & 22.95 & 100.0 & 5 & $06-30-91$ \\
\hline Mingo & $01-31-84$ & 79.1 & 22.95 & 100.0 & 5 & $06-30-89$ \\
\hline Monongalia & $10-05-83$ & 86.3 & 22.95 & 100.0 & 5 & $06-30-89$ \\
\hline Monroe & $12-13-83$ & 73.6 & 13.94 & 60.7 & 5 & $06-30-89$ \\
\hline Morgan & $12-20-83$ & 87.5 & 20.00 & 87.2 & 5 & $06-30-89$ \\
\hline McDowell & $02-07-84$ & 93.5 & 22.95 & 100.0 & 5 & $06-30-89$ \\
\hline Nicholas & $12-10-85$ & 65.0 & 10.00 & 43.6 & 5 & $06-30-91$ \\
\hline Ohio & $06-05-84$ & 65.0 & 22.95 & 100.0 & 5 & $06-30-90$ \\
\hline Pendleton & --- & --- & -- & --- & - & --- \\
\hline Pleasants & $09-20-83$ & 81.0 & 19.95 & 86.9 & 5 & $06-30-89$ \\
\hline Pocahontas & $05-13-86$ & 56.5 & 22.95 & 100.0 & 2 & $06-30-89$ \\
\hline Preston & $10-10-83$ & 85.8 & 22.95 & 100.0 & 5 & $06-30-89$ \\
\hline Putnam & $11-05-85$ & 89.0 & 22.95 & 100.0 & 5 & $06-30-91$ \\
\hline Raleigh & $12-20-83$ & 92.5 & 22.95 & 100.0 & 5 & $06-30-89$ \\
\hline Randolph & $01-31-87$ & 65.6 & 13.77 & 60.0 & 1 & $06-30-88$ \\
\hline Ritchie & --- & --- & --- & --- & - & --- \\
\hline Roane & --- & --- & --- & --- & - & --- \\
\hline Summers & --- & --- & --- & --- & - & --- \\
\hline Taylor & $12-27-85$ & 87.2 & 11.48 & 50.0 & 5 & $06-30-91$ \\
\hline Tucker & --- & --- & -- & --- & - & --- \\
\hline Tyler & $12-04-82$ & 67.7 & 22.95 & 100.0 & 5 & $06-30-88$ \\
\hline Upshur & $01-28-83$ & 81.2 & 22.95 & 100.0 & 5 & $06-30-88$ \\
\hline Wayne & $12-21-83$ & 95.8 & 22.95 & 100.0 & 5 & $06-30-89$ \\
\hline Webster & --- & --- & --- & --- & - & --- \\
\hline Wetzel & $12-14-82$ & 61.0 & 17.21 & 75.0 & 5 & $06-30-88$ \\
\hline Wirt & $09-18-86$ & 78.0 & 20.66 & 90.0 & 5 & $06-30-92$ \\
\hline Wood & $10-04-83$ & 79.2 & 22.95 & 100.0 & 5 & $06-30-89$ \\
\hline Wyoming & $\underline{10-18-83}$ & 95.0 & 22.95 & 100.0 & 5 & 06-30-89 \\
\hline State & 43 & 79.9 & 20.56 & 89.6 & $\underline{4.7}$ & \\
\hline
\end{tabular}


Table A-12

Comparison of Percent Change in Student Enrollment (Net and Adjusted)

Per District Between School Years 1987-1988 and 1996-1997

\begin{tabular}{|c|c|c|c|c|}
\hline \multirow[b]{3}{*}{ County } & \multirow{2}{*}{\multicolumn{2}{|c|}{ Percent Change in Enrollments }} & \multicolumn{2}{|c|}{ Greatest Change (\%) } \\
\hline & & & \multirow{2}{*}{$\begin{array}{c}\text { Net } \\
\text { Enrollment }\end{array}$} & \multirow{2}{*}{$\begin{array}{c}\text { Adjusted } \\
\text { Enrollment }\end{array}$} \\
\hline & Net & Adjusted & & \\
\hline Barbour & -7.28 & -2.74 & -7.28 & --- \\
\hline Berkeley & 20.63 & 21.03 & --- & 21.03 \\
\hline Boone & -21.97 & -10.89 & -21.97 & --- \\
\hline Braxton & -3.83 & -7.07 & --- & -7.07 \\
\hline Brooke & -16.19 & -18.20 & --- & -18.20 \\
\hline Cabell & -10.28 & -9.51 & -10.28 & --- \\
\hline Calhoun & -7.91 & -14.14 & --- & -14.14 \\
\hline Clay & -10.80 & -3.76 & -10.80 & --- \\
\hline Doddridge & -0.24 & 0.98 & --- & 0.98 \\
\hline Fayette & -18.23 & -12.01 & -18.23 & --- \\
\hline Gilmer & -4.55 & -4.57 & --- & -4.57 \\
\hline Grant & -5.72 & -4.43 & -5.72 & --- \\
\hline Greenbrier & -6.51 & -2.40 & -6.51 & --- \\
\hline Hampshire & 23.74 & 27.13 & --- & 27.13 \\
\hline Hancock & -18.66 & -13.40 & -18.66 & --- \\
\hline Hardy & 9.66 & 6.35 & 9.66 & --- \\
\hline Harrison & -3.08 & -1.40 & -3.08 & --- \\
\hline Jackson & -1.22 & -0.91 & -1.22 & --- \\
\hline Jefferson & 7.52 & 14.84 & --- & 14.84 \\
\hline Kanawha & -9.72 & -8.97 & -9.72 & --- \\
\hline Lewis & -11.87 & -4.86 & -11.87 & --- \\
\hline Lincoln & -14.28 & -6.84 & -14.28 & --- \\
\hline Logan & -30.98 & -22.55 & -30.98 & --- \\
\hline Marion & -5.76 & -8.86 & --- & -8.86 \\
\hline Marshall & -9.91 & -8.70 & -9.91 & --- \\
\hline Mason & -6.80 & 2.95 & -6.80 & --- \\
\hline Mercer & -17.98 & -17.46 & -17.98 & --- \\
\hline Mineral & 1.66 & -4.14 & --- & -4.14 \\
\hline Mingo & -28.78 & -18.36 & -28.78 & --- \\
\hline Monongalia & 4.59 & 3.09 & 4.59 & --- \\
\hline Monroe & -8.91 & -14.26 & --- & -14.26 \\
\hline Morgan & 8.16 & 2.16 & 8.16 & --- \\
\hline McDowell & -34.33 & -26.70 & -34.33 & --- \\
\hline Nicholas & -6.59 & -5.63 & -6.59 & --- \\
\hline Ohio & -1.76 & -8.87 & --- & -8.87 \\
\hline Pendleton & 4.40 & -7.17 & --- & -7.17 \\
\hline Pleasants & -1.15 & 8.31 & --- & 8.31 \\
\hline Pocahontas & -3.11 & -4.41 & --- & -4.41 \\
\hline Preston & -10.53 & -9.41 & -10.53 & --- \\
\hline Putnam & 11.70 & 19.83 & --- & 19.83 \\
\hline Raleigh & -15.72 & -5.56 & -15.72 & --- \\
\hline Randolph & 2.43 & -1.25 & 2.43 & --- \\
\hline Ritchie & -3.19 & 4.92 & --- & 4.92 \\
\hline Roane & -4.56 & -7.82 & --- & -7.82 \\
\hline Summers & -20.98 & -19.57 & -20.98 & --- \\
\hline Taylor & -4.61 & -2.58 & -4.61 & --- \\
\hline Tucker & -6.85 & -10.70 & --- & -10.70 \\
\hline Tyler & -15.31 & -13.41 & -15.31 & \\
\hline Upshur & -4.61 & -3.22 & -4.61 & --- \\
\hline Wayne & -11.03 & -3.22 & -11.03 & --- \\
\hline Webster & -25.01 & -23.44 & -25.01 & --- \\
\hline Wetzel & -5.58 & -4.01 & -5.58 & --- \\
\hline Wirt & 15.10 & 15.47 & --- & 15.47 \\
\hline Wood & -4.55 & -11.49 & --- & -11.49 \\
\hline Wyoming & -31.02 & -25.75 & -31.02 & --- \\
\hline State & -9.15 & -6.77 & 34 & 21 \\
\hline
\end{tabular}

Note: Certified adults included in net enrollment beginning with 1988-1989 school year. 
Table A-13

Comparison of Unreserved Fund Balances (General Current Expense Fund) Per District for Fiscal Years Ended June 30, 1988 and 1997

\begin{tabular}{|c|c|c|c|}
\hline \multirow[b]{2}{*}{ County } & \multicolumn{2}{|c|}{ Fiscal Year Ended } & \multirow{2}{*}{$\begin{array}{l}\text { Increase } \\
\text { (Decrease) }\end{array}$} \\
\hline & $06-30-1988$ & $06-30-1997$ & \\
\hline Barbour & 298,243 & 105,603 & $(192,640)$ \\
\hline Berkeley & $(141,768)$ & $1,299,504$ & $1,441,272$ \\
\hline Boone & 461,155 & $6,610,151$ & $6,148,996$ \\
\hline Braxton & 177,965 & 41,443 & $(136,522)$ \\
\hline Brooke & 747,705 & 141,786 & $(605,919)$ \\
\hline Cabell & $3,075,971$ & $1,981,561$ & $(1,094,410)$ \\
\hline Calhoun & 362,334 & 3,090 & $(359,244)$ \\
\hline Clay & 6,381 & $(180,410)$ & $(186,791)$ \\
\hline Doddridge & 463,303 & $(107,355)$ & $(570,658)$ \\
\hline Fayette & $4,246,111$ & $2,043,619$ & $(2,202,492)$ \\
\hline Gilmer & $(\mathbf{1 7 3 , 2 0 9 )}$ & 122,715 & 295,924 \\
\hline Grant & 204,907 & $(55,380)$ & $(260,287)$ \\
\hline Greenbrier & $1,046,802$ & 844,279 & $(202,523)$ \\
\hline Hampshire & 95,720 & 213,951 & 118,231 \\
\hline Hancock & 195,541 & 379,976 & 184,435 \\
\hline Hardy & 285,005 & 28,943 & $(256,062)$ \\
\hline Harrison & 244,239 & 51,016 & $(193,223)$ \\
\hline Jackson & 189,831 & $1,076,090$ & 886,259 \\
\hline Jefferson & 414,016 & 419,779 & 5,763 \\
\hline Kanawha & 509,412 & $6,967,733$ & $6,458,321$ \\
\hline Lewis & 996,442 & $(\mathbf{7 9 6 , 5 1 8 )}$ & $(1,792,960)$ \\
\hline Lincoln & 342,169 & $(254,021)$ & $(596,190)$ \\
\hline Logan & 454,211 & 942,749 & 488,538 \\
\hline Marion & 594,244 & 592,404 & $(1,840)$ \\
\hline Marshall & 890,213 & $1,257,963$ & 367,750 \\
\hline Mason & 245,541 & 327,550 & 82,009 \\
\hline Mercer & $1,910,727$ & $1,623,051$ & $(287,676)$ \\
\hline Mineral & 293,763 & 954,010 & 660,247 \\
\hline Mingo & 317,379 & $(2,377,448)$ & $(2,694,827)$ \\
\hline Monongalia & $1,438,628$ & $1,453,794$ & 15,166 \\
\hline Monroe & 254,536 & $(400,501)$ & $(655,037)$ \\
\hline Morgan & 324,615 & $1,151,063$ & 826,448 \\
\hline McDowell & 321,670 & 381,409 & 59,739 \\
\hline Nicholas & $1,667,421$ & 167,836 & $(1,499,585)$ \\
\hline Ohio & 813,212 & 137,606 & $(675,606)$ \\
\hline Pendleton & 244,110 & 31,929 & $(212,181)$ \\
\hline Pleasants & 472,094 & 248,599 & $(223,495)$ \\
\hline Pocahontas & 867,361 & 48,182 & $(819,179)$ \\
\hline Preston & $(22,452)$ & 189 & 22,641 \\
\hline Putnam & $1,989,784$ & $1,384,645$ & $(605,139)$ \\
\hline Raleigh & $1,137,389$ & 520,743 & $(616,646)$ \\
\hline Randolph & 648,326 & 266,860 & $(381,466)$ \\
\hline Ritchie & 4,460 & $(449,582)$ & $(454.042)$ \\
\hline Roane & 164,442 & 69,075 & $(95,367)$ \\
\hline Summers & 142,353 & $(83,662)$ & $(226,015)$ \\
\hline Taylor & $(39,530)$ & 525,015 & 564,545 \\
\hline Tucker & 122,257 & 186,480 & 64,223 \\
\hline Tyler & 233,261 & 470,092 & 236,831 \\
\hline Upshur & $1,712,197$ & $(228,239)$ & $(1,940,436)$ \\
\hline Wayne & 80,298 & 57,070 & $(23,228)$ \\
\hline Webster & 102,385 & 43,333 & $(59,052)$ \\
\hline Wetzel & $(\mathbf{5 8 , 5 7 4})$ & 623,562 & 682,136 \\
\hline Wirt & 87,552 & 163,501 & 75,949 \\
\hline Wood & 272,269 & 482,015 & 209,746 \\
\hline Wyoming & 221,529 & $1,591,079$ & $1,369,550$ \\
\hline Total & $31,955,946$ & $33,099,927$ & $1,143,981$ \\
\hline
\end{tabular}

Number with deficits

10

Note: County boards with deficit unreserved fund balances highlighted in bold. 
APPENDIX B

PANEL OF EXPERTS WHO REVIEWED

SURVEY INSTRUMENT 


\section{Panel of Experts Who Reviewed the Survey Instrument}

Dr. Martha Dean, Superintendent Wetzel County Schools 333 Foundry Street

New Martinsville, West Virginia 26155

Joseph P. Panetta, Executive Director School Finance West Virginia Department of Education

Room B 215

Charleston, West Virginia 25305

Harry G. Reustle, Treasurer

Kanawha County Schools

200 Elizabeth Street

Charleston, West Virginia 25311

Dr. Kenna Seal, Executive Director

Office of Education Performance Audits

(former Superintendent of Braxton County Schools)

550 Eagan Street

Charleston, West Virginia 25301 
APPENDIX C

SUPERINTENDENT AND TREASURER

LETTERS AND QUESTIONNAIRE 
Dear (Superintendent):

Working with Phyllis Durden and West Virginia University's Advanced Educational Studies Department in the College of Human Resources and Education, I am conducting a research study to learn how legislative mandated changes in the foundation formula and management response by boards of education influenced the number of financial deficits experienced by the fifty-five school districts of West Virginia. Your cooperation and participation are critical to ensuring a study that adequately reflects your perception of the factors leading to financial deficits.

Superintendents and Treasurers of the county boards of education throughout the state are being surveyed. Your participation is entirely voluntary and you do not have to respond to every item or question. Your responses will remain anonymous and confidentiality will be maintained. Please complete the attached questionnaire and return it in the enclosed envelope by July 1,1999. The results of the survey will be shared with you at the end of the study.

Thank you for your cooperation.

Sincerely,

\section{David Stewart}

\section{Enclosures}


June 1, 1999

Dear (Superintendent):

Working with Phyllis Durden and West Virginia University's Advanced Educational Studies Department in the College of Human Resources and Education, I am conducting a research study to learn how legislative mandated changes in the foundation formula and management response by boards of education influenced the number of financial deficits experienced by the fifty-five school districts of West Virginia. Your cooperation and participation are critical to ensuring a study that adequately reflects your perception of the factors leading to financial deficits.

Superintendents and Treasurers of the county boards of education throughout the state are being surveyed. Your participation is entirely voluntary and you do not have to respond to every item or question. Please complete the attached questionnaire and return it in the enclosed envelope by July 1, 1999. You do not have to answer each question. The results of the survey will be shared with you at the end of the study.

Thank you for your cooperation.

Sincerely,

David Stewart

Enclosures 
June 1, 1999

Dear (Treasurer):

Working with Phyllis Durden and West Virginia University's Advanced Educational Studies Department in the College of Human Resources and Education, I am conducting a research study to learn how legislative mandated changes in the foundation formula and management response by boards of education influenced the number of financial deficits experienced by the fifty-five school districts of West Virginia. Your cooperation and participation are critical to ensuring a study that adequately reflects your perception of the factors leading to financial deficits.

Superintendents and Treasurers of the county boards of education throughout the state are being surveyed. Your participation is entirely voluntary and you do not have to respond to every item or question. Please complete the attached questionnaire and return it in the enclosed envelope by July 1, 1999. You do not have to answer each question. The results of the survey will be shared with you at the end of the study.

Thank you for your cooperation.

Sincerely,

David Stewart

Enclosures 


\section{QUESTIONNAIRE}

County

County boards of education have increasingly experienced budget deficits as reported on the annual financial statements. The deficits have increased in number since the reform movement of 1988. Senate Bill 14 initiated the first reduction of the number of professional and service personnel funded in the Public School Support Plan, known hereafter as the "formula." In 1990 additional legislation was enacted to reduce the number of administrators eligible for funding in the "formula." The following questions are designed to learn what affect these changes among others enacted by the legislature have on the financial operations of the county boards of education.

Please respond by marking the response that describes how the legislation impacted the annual financial statements between June 30, 1988 and June 30, 1997 for your county school district. Space for example(s) illustrating your response(s) follows each question. Answers must describe the time period being studied.

1. To what extent did the reduction of personnel funded in the formula cause the increased incidence of budgets deficits?

a. Major factor

b. Moderate factor

c. Not at all

Provide examples of actions taken by the county board of education to align the number of personnel employed with the number funded in the formula. (Use additional pages if necessary.)

2. What steps did county boards of education take to avoid deficit spending? (Mark all that apply.)

a. Reduce professional staff

b. Reduce service staff

c. Reduce administrative staff

d. Close/Consolidate schools

e. Defer expenditures

f. No action taken 
Provide examples of steps taken by the county board of education to avoid deficit spending. (Use additional pages if necessary.)

3. Did county boards of education experience a budget deficit prior to 1988 ?

a. No

b. Yes

If your county experienced a budget deficit prior to 1988, in what year did the deficit occur and what were the contributing factors? (Use additional pages if necessary.)

4. What policies and practices are counties continually implementing to avoid a budget deficit?

a. Maintain staff at the level funded by the formula.

b. Staffing above the formula using excess levy funds.

c. Close/Consolidating schools

d. Deferring expenditures

Provide examples of practices your county has in place to avoid a budget deficit. (Use additional pages if necessary.)

5. If closure and consolidation of schools were used to avoid deficit spending what was the impact on the budget?

a. Deficit spending did not occur

b. Deficit spending did occur

c. No impact 
Provide examples of expenditure savings or increases to support your answer. (Use additional pages if necessary.)

6. What was the effect of continuing budget deficits on the academic and extra curricular programs? (Use additional pages if necessary.)

7. Provide any comments which you feel are relevant to this survey and the contributing factors to budget deficits between June 30, 1988 and June 30, 1998. (Use additional pages if necessary.)

Thank you and please return by in the enclosed stamped and preaddressed envelope to:

David Stewart

615 Bendview Drive

Charleston, WV 25314 
APPENDIX D

APPROVAL LETTER OF

APPLICATION FOR EXEMPTION 
May 18, 1999

\section{MEMORANDUM}

TO: $\quad$ David Stewart

FROM: $\quad$ Ernest R. Goeres

Associate Dean

RE: $\quad$ Human Resources \& Education H.S. \#99-052

Title: "Common Factors Leading to County Boards of Education Financial Deficits"

Your Application for Exemption for your above-captioned research project has been reviewed under the Human Subjects Policies and has been approved. Attached is the original of your cover letter with the signed stamp of approval. This must accompany your survey or questionnaire.

This exemption will remain in effect on the condition that the research is carried out exactly as described in the application.

Best wishes for the success of your research.

cc: Deans Office

Student Advising and Records

Phyllis Durden, Advisor 
VITA

David L. Stewart

615 Bendview Drive

Charleston, West Virginia 25314

\section{EDUCATION:}

2000

West Virginia University

Morgantown, West Virginia

Doctor of Education in Educational Leadership Studies

1975

University of West Virginia, College of Graduate Studies

Institute, West Virginia

Master's Degree - Major in Education Administration

1972

Morris Harvey College

Charleston, West Virginia

Teacher Certification in Elementary Education

1966

Anderson University

Anderson, Indiana

Bachelor's Degree - Major in Business Administration/

Accounting; Minor in Psychology

\section{EXPERIENCE:}

March, 2000 -

State Superintendent of Schools

Present

West Virginia Department of Education

Charleston, West Virginia

July, 1998 -

Assistant State Superintendent of Schools

March, 2000

West Virginia Department of Education

Charleston, West Virginia

July, 1996 -

Associate Superintendent/Treasurer

July, 1998

Kanawha County Schools, 200 Elizabeth Street

Charleston, West Virginia

September, 1993 - Assistant Division Chief, Administrative Services

June, 1996

West Virginia Department of Education

Charleston, West Virginia 


\begin{tabular}{|c|c|}
\hline $\begin{array}{l}\text { July, } 1993 \text { - } \\
\text { September, } 1993\end{array}$ & $\begin{array}{l}\text { Treasurer } \\
\text { Kanawha County Schools, } 200 \text { Elizabeth Street } \\
\text { Charleston, West Virginia }\end{array}$ \\
\hline $\begin{array}{l}\text { March, } 1993- \\
\text { June, } 1993\end{array}$ & $\begin{array}{l}\text { Interim Superintendent } \\
\text { Kanawha County Schools, } 200 \text { Elizabeth Street } \\
\text { Charleston, West Virginia }\end{array}$ \\
\hline $\begin{array}{l}\text { August, } 1990- \\
\text { February, } 1993\end{array}$ & $\begin{array}{l}\text { Assistant Superintendent/Treasurer } \\
\text { Kanawha County Schools, } 200 \text { Elizabeth Street } \\
\text { Charleston, West Virginia }\end{array}$ \\
\hline $\begin{array}{l}\text { February, } 1990- \\
\text { July, } 1990\end{array}$ & $\begin{array}{l}\text { Director of Business/Finance } \\
\text { Christina School District, } 83 \text { Main Street } \\
\text { Newark, Delaware }\end{array}$ \\
\hline $\begin{array}{l}\text { August, } 1989 \text { - } \\
\text { January, } 1990\end{array}$ & $\begin{array}{l}\text { Executive Associate Superintendent for Business } \\
\text { Kanawha County Schools, } 200 \text { Elizabeth Street } \\
\text { Charleston, West Virginia }\end{array}$ \\
\hline $\begin{array}{l}\text { August, } 1983- \\
\text { August, } 1989\end{array}$ & $\begin{array}{l}\text { Assistant Superintendent, Budget \& Finance } \\
\text { Kanawha County Schools, } 200 \text { Elizabeth Street } \\
\text { Charleston, West Virginia }\end{array}$ \\
\hline $\begin{array}{l}\text { February, } 1981- \\
\text { August, } 1983\end{array}$ & $\begin{array}{l}\text { Director of Budget and Accounting } \\
\text { Kanawha County Schools, } 200 \text { Elizabeth Street } \\
\text { Charleston, West Virginia }\end{array}$ \\
\hline $\begin{array}{l}\text { December, } 1978 \text { - } \\
\text { February, } 1981\end{array}$ & $\begin{array}{l}\text { Coordinator of Purchasing } \\
\text { Kanawha County Schools, } 200 \text { Elizabeth Street } \\
\text { Charleston, West Virginia }\end{array}$ \\
\hline $\begin{array}{l}\text { July, } 1977 \text { - } \\
\text { December, } 1978\end{array}$ & $\begin{array}{l}\text { Principal, Piedmont Elementary School } \\
203 \text { Bradford Street } \\
\text { Charleston, West Virginia }\end{array}$ \\
\hline $\begin{array}{l}\text { December, } 1972 \text { - } \\
\text { July, } 1977\end{array}$ & $\begin{array}{l}\text { Teacher and Lead Teacher, Piedmont Elementary School } \\
203 \text { Bradford Street } \\
\text { Charleston, West Virginia }\end{array}$ \\
\hline $\begin{array}{l}\text { February, } 1970 \text { - } \\
\text { December, } 1972\end{array}$ & $\begin{array}{l}\text { President, Stewart Equipment Company, Inc. } \\
\text { Charleston, West Virginia }\end{array}$ \\
\hline
\end{tabular}


May, 1969 - Weapons Control and Education Officer, Instructor

February, 1970 Technical Training School, Tyndall AFB

Panama City, Florida

May, 1968 - $\quad$ Officer, United States Air Force

May, 1969 Republics of Vietnam and Korea

September, 1966 - Commissioned Officer, United States Air Force

May, 1968 Weapons Flight Officer and Instructor

\section{HONORS:}

Junior Officer of the Year - Tyndall AFB, Panama City Florida, 1967

National Defense Medal, United States Air Force

Armed Forces Expeditionary Medal, United States Air Force

Presidential Citation, United States Air Force

United States Air Force Commendation Medal, United States Air Force

CIVIC AND FRATERNAL ORGANIZATIONS:

Board of Directors, Boy Scouts of America, Buckskin Council

Member, Administrative Board, Christ Church United Methodist

Board of Directors, Kanawha County Public Library

\section{SPECIAL ACCOMPLISHMENTS:}

Consultant for Organization and Staff Development (K-8), Barlow-Vincent

Elementary School, Barlow, Ohio - August, 1973

Coordinator for Inservice, Barlow-Vincent Elementary, April, 1974

Team Leader, Career Opportunities Program, Kanawha County Schools, 1975

United States Office of Education Title III Validator, Plains Elementary, Timberville, Virginia, 1975 
North Central Association Steering Committee Chairman, North Central Evaluation, Piedmont Elementary School, 1976

ESAA Advisory Council, 1976

Building Coordinator of Teaching to Optimize the Potential of Students T.O.P.S. Summer Program, Piedmont Elementary School, 1978

National Institute of Governmental Purchasing, Inc., "Basics of Public Purchasing" Seminar, 1979

Personal Predictions and Research, "Improving Interpersonal Skills with Social Style," 1984

Superintendent's Award for Excellence in Job Performance, 1986

National Academy for School Executives, "Innovative Budgeting and Management Systems," 1987

Southeastern Association of School Business Officials, "Equity Funding in Public Schools," 1994

\section{PROFESSIONAL ORGANIZATIONS:}

West Virginia Association for School Business Officials

International Association for School Business Officials

West Virginia Association of School Administrators

American Association of School Administrators 